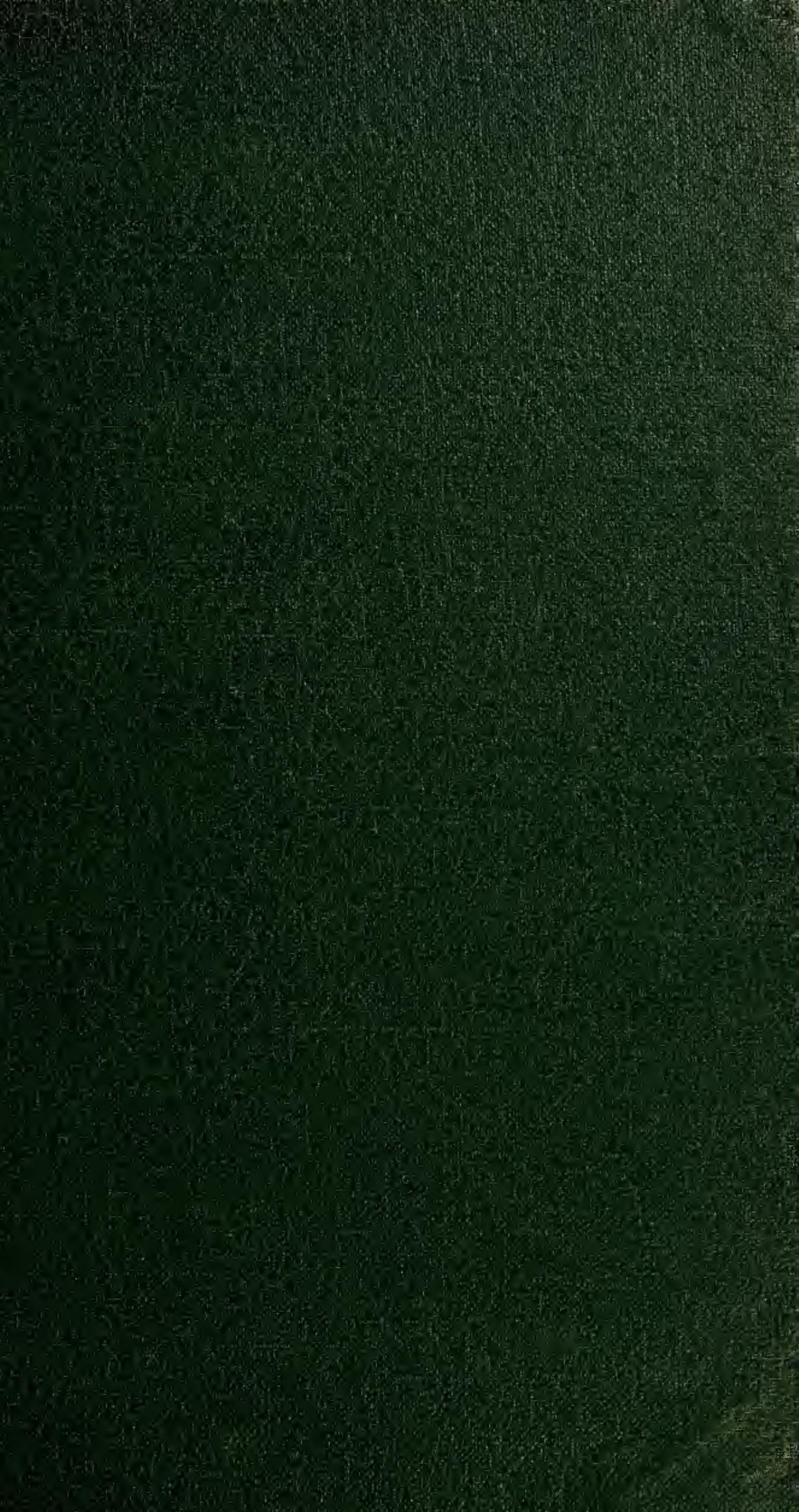





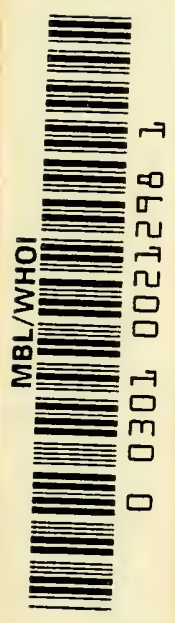





\title{
INJURY AND DEATH
}

$\mathrm{OF}$

BACTERIA

BY

\section{CHEMICAL AGENTS}

\author{
OTTO RAHN \\ Profresor of Bacteriology

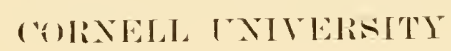

No. 3 of the "Biodynamica Monograuphs" rdited by B. J. Luset

Published by

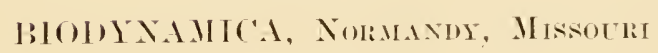

1945 



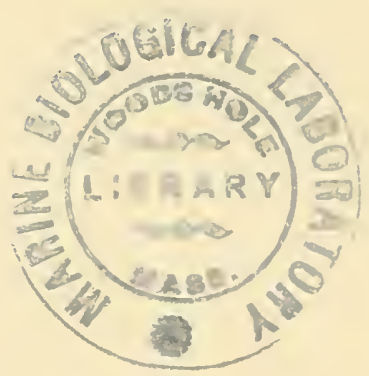

The contents of this monograph, except for a few additions and some minor modifications, are reprinted from Broprsınicı, No. 86, 1943 and No. 96,1945 . 



\section{FOREWORI)}

The problem of the mechanism of death and that of the mode of action of poisonous substances have been among the favorite subjects of onr program of publication. We, therefore, welcome the opportunity of editing this monograph.

The author's forty years of laboratory experience with bacteria and his constant interest in the fundamental problems of biology recommend him both for knowing "the facts" and for being one of those who try to "get to the bottom of things.",

His notion that "cell mechanisms," corresponding to the various physiological functions, are affected individually by disinfectants, and that injury and death are the result of an impairment or a destruction of some of these mechanisms, will give rise, we expect, to fruitful discussions.

New arguments are adranced, in the first part of the monograph, in favor of the idea that the survivor curves of bacteria-and, according to the author, of nnicellular or.ganisms in general-are exponential. There are many opponents of this idea (among them the present editor). Professor Rahn's arguments will force these opponents to give thought to some aspects of the subject which they might otherwise overlook.

The author's attempt to bring some system into the study of the action of that group of substances which stop, delay, $\mathrm{or}^{*}$ otherwise impede the activity of bacteria, without killing them, will be of particnlar interest to those who know how much of a "mix-up" this subject is.

June 1, 1945

Saint Louis, Missonri

B. LuYet. 



\section{TABLE OF CONTENTS}

PAGE

FOREWORD

TABLE OF CONTENT'S ............................................ 7

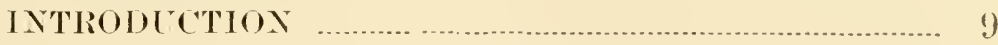

PART I

THE PROBLEM OF THE LOGARITHMIC ORDER OF DEATH IN BACTERIA

I. The Order of Death 13

II. Order of Death in Mrulticellular Versus Unicellular Organisms 20

III. The Cause of the Logarithmic Urder of Death.. 28

The Deathrate Constant. 29

Explanations of the Logarithmic Order. 31

Mass Law and single Molecules. 37

IV. Conditions Resulting in a Non-Logarithmic Order of Deatl 42

Cell Clusters and Chain Formation..................... 42

The Effect of the Age of the Coll ......................... 42

The Order of Death in the Case of Low Death. rates

The Order of Death of Cther I nicellular Oranisms

Enexplained Deviations from the Logarithmic Order

T. Biological Consequences of the Logarithmic Order of Death. 54

Imprortance of the Number of Individuals.......... 54

selection of Resistant Strains 56

Protection of Living by Dearl Cells. $5 S$

\section{PART II \\ MODE OF ACTION OF DISINFECTANTS AND \\ ANTISEPTICS}

I. IISINFECTANTS

I. Selectivity of Disinfectants 63

II. Concentration and Death Rate 66 
III. Temperature and Disinfection Page

Temperature coefficients of Life and neath....... 78

IV. Interference of Foreign Matter. With Disinfec-

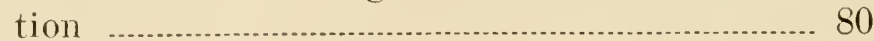

V. Interference of Antidotes With Disinfection.... 82

VI. Properties of Tarious Groups of Disinfectants.. 84

$\lambda$ dids

Alkalies _...................... 85

Heary Metal rompmuds........... _ _ _ . 85

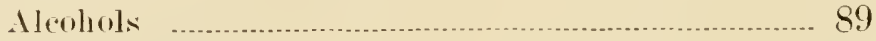

Formaldehride _....................... 90

Gxidizing Igents

Halogens _.._ _ _ _ _ 92

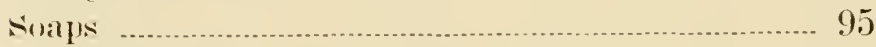

VII. Standardization of Disinfectants.....................101

\section{ANTISLPTICS}

1. Temperature and Antisepsis...............................

1I. Selective Action of Antiseptics.......................123

III. Diluted Disinfectants as Antiseptics__...............128

IV. Effect of Size of Inoculum _............................

V. The Dual Action of the Dyes......................136

VT. Mode of Action of the Sulfonamides...................146

TII. Increased Efficiency of the Weak Acids by Increased Acidity -................................................

VIII. Antagonistic Substances From Microorgan-

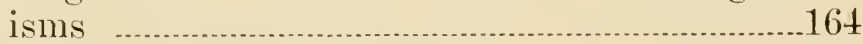

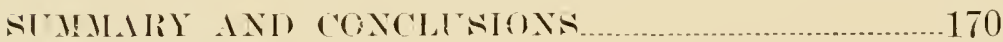

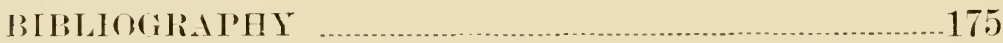

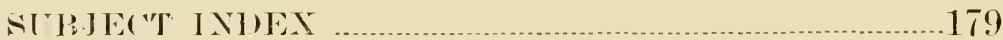

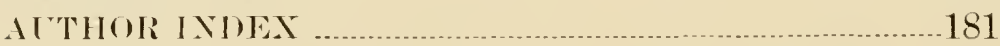




\section{INTRODUCTION}

To understand the death of multicellular organisms, it seems necessary to be acquainted with the death of indiridual cells. This book deals with the death of single cells, and although bacteria are not in all respects directly comparable with tissue cells, the fundamental principles involved in death are the same. The study of the reath of bacteria furnishes, therefore, a solid foundation for a general study of death.

Extensive researches on disinfection and sterilization have resulted in a great deal of detailed information on the death of bacteria. An attempt is made in this book to sort out the experimental evidence and to search for the basic reactions which cause death.

A study of death shonld logically begin with a definition of death, but right there, difficulties arise. Death camnot be defined by positive criteria ; it can be characterized only by the absence of some property which is essential to life. But different groups of biologists differ in their views on the most essential properties of living organisms. The death of a cell is not always determined by the same method; the loss of motility, of respiration or of other enzyme activities, the increase in permeability which makes plasmolysis impossible and causes the absorption of dyes, are variously used as criteria of death. These criteria do not always appear simultaneously (Rahn and Barnes, 1933) because, as will be shown, they indicate an inactivation of different cellular mechanisms. Thus, a cell may be alive according to one definition, and dead according to another.

The bacteriologist has no choice of definition because bacteria are too small to permit an easy study of any of the above criteria. The criterion almost universally used by lim to define death is the loss of reproduction. All standard methods used in the study of disinfection and 
sterilization measure the death of bacteria by their inability to produce colonies, or to make a culture medium cloudy. It has been frequently overlooked in the general study of death that, to the bacteriologist, a cell is dead when it is sterile, i.c., permanently mable to reproduce. Sooner or later such cells will also lose the other, more conspicuous properties characteristic of life. Although, with linger animals, sterility of the organism is not identical with death, any organism in which the individual cells have lost the ability to multiply will sooner or later lose the other, more conspicuous properties of life.

The different criteria of death mentioned above refer to the inactivation of different mechanisms which are indispensable for the life and reproduction of the cell. These mechanisms can be divided into five groups, according to the functions they control:

Gromp I: Mechanisms controlling the passage of substances into and out of the call; they are represented by the cell membrane.

Group II : Mechanisms controlling the energy production for all life activity; they consist of enzymcs.

Group III: The synthesis mechanism which probably involves a large number of different catalysts that control the synthesis of the cell constituents from the food.

Group IV: The multiplication mechanism: known in higher organisms to have its seat in the nucleus.

Group V: Mechanisms consisting of protein molecules which often make up the bulk of the cytoplasm, but are without definitely known physiological function, though they are essential for the life of the cell since their denaturation causes death. (Such are myosin, leguminin, glutinin, the globulins of bacteria, etc.) 
These mechanisms either consist of pure proteins, like the chromosomes, or their major part is such, as in the case of the membrane.

The first two and the last of the mechanisms listed are probably independent of each other, while multiplication cannot take place without synthesis, and synthesis cannot take place without energy, i.e., without enzyme action.

A partial or even complete inactivation of mechanisms II or $\mathrm{V}$ need not cause death if the synthesis mechanism can replace thenl. Syuthesis has been observed, under abnormal conditions, to continue while multiplication was lost, resulting in single cells of very great length. These cells are considered dead by the bacteriologist; in fact, they disintegrate som after they have ceased to increase.

This consideration brings us to the problem of injury to the cell. Boycott (1920) was led to believe from the trend of the death curves obtained with bacteria that they might be too simply organized to recover from injury. However, it seems that any organism that has the ability to grow must have the ability to repair a certain amount of injury. In multicellular organisms, recovery is frequently not a repair of the injured cells, but is accomplished through their replacement by new cells which are produced by surrounding, uninjured tissues. Similarly, in micellular organisms, damaged protein molecules may be replaced by new molecules produced by the minjured synthesis mechanisno. Native proteins are unstable, and the cell is continuously replacing inactivated molecules. The same synthesis mechanism which originally formed all the cell constituents, and replaces all mechanisms that deteriorate in the "wear and tear" of life, may even work more rapidly in case of injury, though within narrow limits.

A special kind of injury is of common occurrence in bacteria, namely, a temporary and reversible loss of re 
productive power. Such is the effect of antisepties (as opposed to that of disinfectants). The removal of the antiseptic permits normal multiplication again. (In higher organisms too, a reversible cessation of growth ean be brought about by application of toxic substances, but we lo not usually think of it as a parallel to antisepsis.)

The course of death of bacteria is different from that of all multicellular organisms, the death time being related logarithmically to the number of surviving bacteria. This "logarithmic order of death" is emphasized in Part I of this monograph becanse it is the key to the understanding of the fundamental cause of death and of the ultimate lethal reaction. The conclusions from Part I are userl in Part II to explain the canse of death by disinfectants. Besides, Part II shows the great differences between the mode of action of disinfectants and that of untiseplics. 


\section{PART I}

\section{THE PROBLEM OF THE LOGARITHMIC ORDER OF IDEATH IN BACTERIA}

\section{THE ORDER OF DEATH}

Organisms which die as a result of a chemical reaction die in an orderly, predictable way. 'T'wo methods of graphic presentation of such orderly deaths are customary. One consists in the use of mortulity curves, which are represented by black blocks in Figme 1, and which give the number of individuals dying in each successive time unit; this type of curve is commonly used in medical statistics. In the other method use is made of survivor curves, which show the number of individuals still living at any time after the beginning of exposure. This type of curve, shown by the thin lines of Fig. 1, is used by bacteriologists, entomologists and plant pathologists.

The order of death is, in principle, the same for all multicellular organisms. The mortality curve begins at zero, and frequently remains at zero for some time, as long as all individuals can recover after short exposures; then the first individuals die, the frequency of death gradually increases to a maximum, then decreases, usually at a slower rate, until only a few very resistant organisms remain, and at last even they succumb.

Whether tadpoles, insects, or plant seeds are tested, whether heat or rays or chemicals are used, the mortality curve remains essentially the sime. These mortality and survivor curves agreed so well with our conception of gradation in resistance that not much attention was paid to them. They were taken for granted until Madsen and Nyman in 1907 and Harriet Chick in 1908 

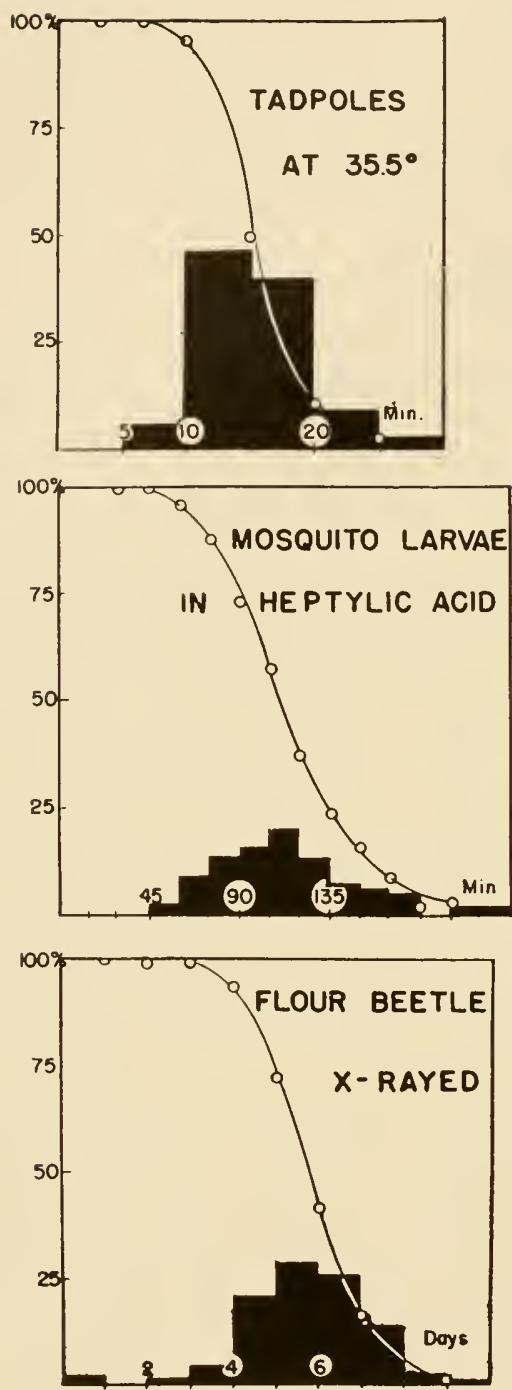
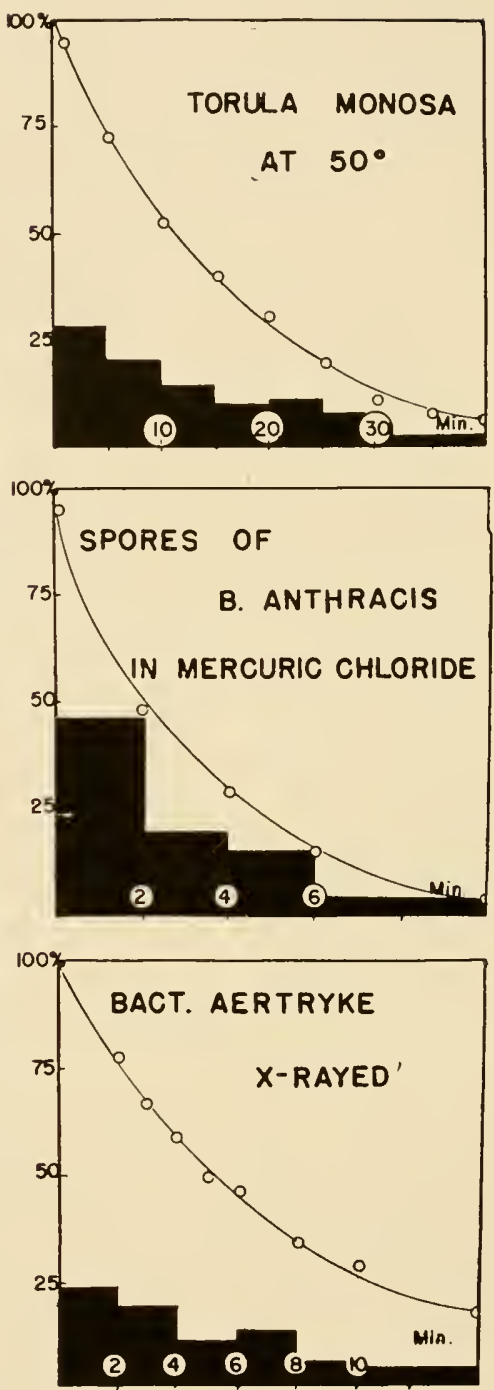

Fig. 1. Mortality curves (black blocks) and survivor curves (thin lines) of various organisms dying under the action of various killing agents. Abscissa: time of exposure; ordinate: per cent of survivors. (From data of Boycott, 1920, for tadpoles; of O'Kane, Westgate and Clover, 1934, for mosquito larvae; of Davey, 1917, for flour beetle; of Beamer and Tanner, 1939, for Torula: of Madsen and Nyman, 1907, for B. anthracis; of Wyckoff, 1930, for B. aertryte.) 

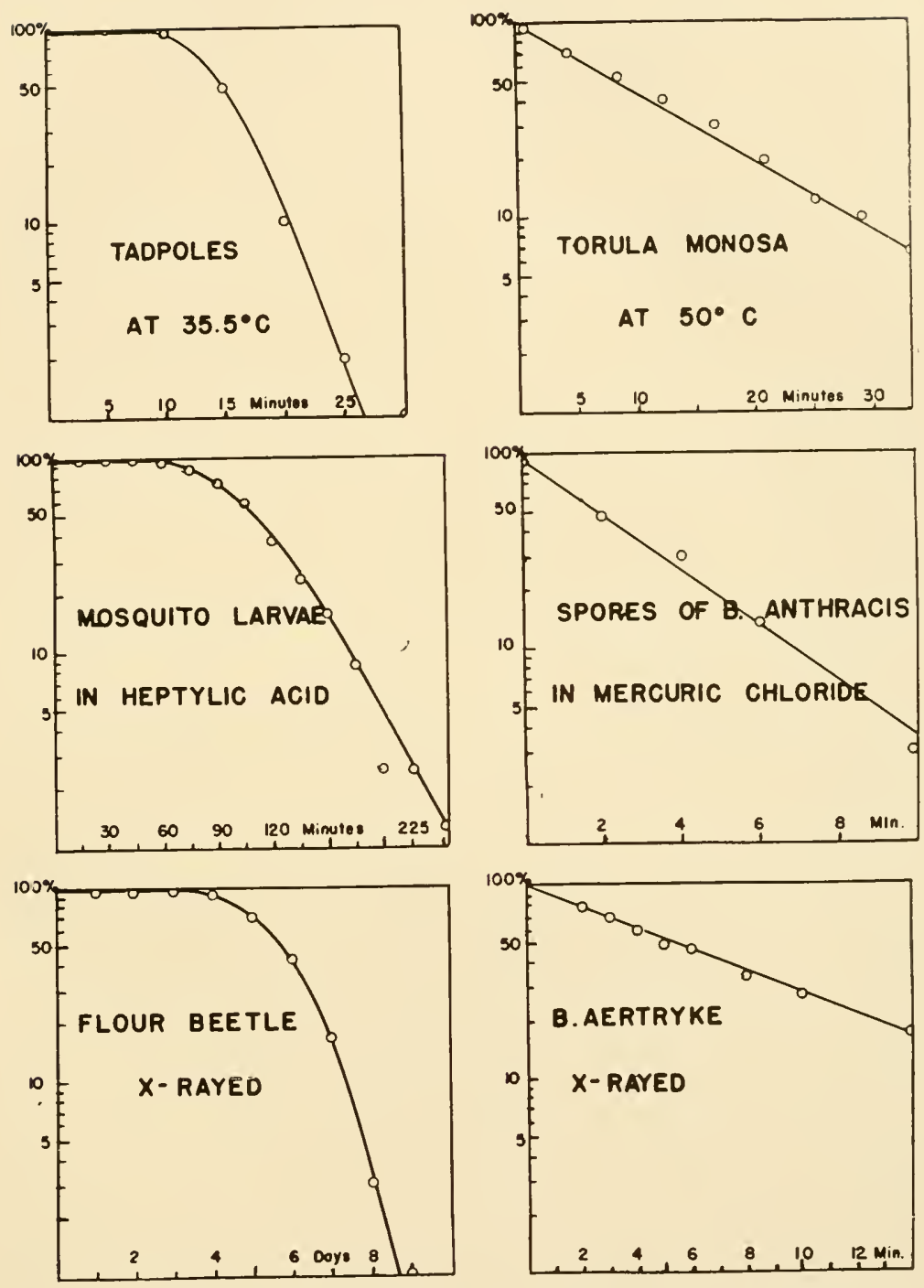

Fig. 2. Semi-logarithmic plot of the survivor curves represented in Fig. 1. Abscissa: time of exposure; ordinate: per cent of survivors on logarithmic scale. 
found that bacteria die in quite a different order. This seemed so umusual and so significant that much experimental work and many theoretical discussions have been published to explain this interesting phenomenon. If the culture for an experiment on the order of death is carefully chosen, not too young and not too old, the bacteria die at a constant rate. This means that the same percentage of all bacteria alive at any given time will die in the next time unit. If, for instance, one-half of the bacteria die in the first minute of exposure, one-half of the remaining bacteria will die in the second mimnte. This leaves onefourth alive, of which again one-half will die during the third minute and so forth. The survirors represent a geometrical progression. If $a$ is the original number, and $s$ the pereentage of survivors, then the actual number of surrivors in successive time units will be

a $a \frac{s}{100} a\left(\frac{s}{100}\right)^{2} \quad a\left(\frac{s}{100}\right)^{3} \cdots a\left(\frac{s}{100}\right)^{t}$

If $s=10$ (that is, if the survival rate is $10 \%$ ) and $a=$ $1,000,000$ bacteria, the successive numbers of survivors will be

$\begin{array}{lllllllll}1,000,000 & 100,000 & 10,000 & 1,000 & 100 & 10 & 1 & 0.1 & 0.01\end{array}$

A geometrical progression can be recognized graphically by the straight line that one obtains by plotting the logarithms of its members against their exponents. Since, in a disinfection experiment, the number of surviving bacteria plotted logarithmically against the time of exposure, furnish a straight line, it has become customary to speak of a "logarithmic order of death" of bacteria.

Figure 1 shows mortality curves and survivor curves. The left side represents multicellular organisms, the right side, bacteria. Figure 2 gives the corresponding survivor curves in semi-logarithmic plotting. With bacteria, they are almost rectilinear; with higher organisms, they are concave downwards. 
Table 1 gives other examples. The difference in the order of death between bacteria and multicellular organisms is here shown by the computation of the value

$$
\mathrm{K}=\frac{1}{\mathrm{t}} \log \frac{\text { initial number }}{\text { survivors }}
$$

This ralue, the "deathrate constant," is constant if the order of death is logarithmic (see p. 30). The table shows that, with bacteria, the successive values for $K$ either fluctuate around an arerage, or eventually decrease with time, while, with higher organisms, they increase.

When no special effort is made to experiment with a homogeneous material, the survivor curve may not be straight but concave upwards. This is in fact the most frequent occurrence. This type of curve differs from that of higher organisms still more than the rectilinear curve. Its concavity is due to lack of uniform resistance. The more sensitive bacteria will die rapidly, causing a steep decline in the number of survivors. When most of these bacteria are dead, the remaining ones die at a lower rate, and as the less resistant individuals are gradually removed, the survivor curve becomes less and less steep.

A simple, theoretical example is given in Table 2. Three groups of bacteria, each containing 1,000 individuals, are supposed to be mixed and exposed to heat. Each group represents a different degree of resistance, the individuals of one group dying at the rate of $90 \%$ per minute, those of the other two groups at $50 \%$ and $10 \%$, respectively. The death rate of the composite sample is not increasing as it would be with higher organisms of graded resistance, but it is decreasing. The survivor curve (Fig. 3) is concave upwards, not downwards.

1. Unless otherwise indicated, the discussion of the characters of survivor curves will always refer to semi-logarithmic plots. 
TABLE 1

Mortality and death rate constants of different organisms dying under the action of various killing agents.

(Data on fruit flies, by Loeb and Northrop, 1917; on mustard seeds. by Hewlett, 1909; on flour beetle, by Darey, 1917; on Bact. coli (heat), by Watkins, 1932; on Bact. paratyphosum, by Chick, 1908; on Bact. coli (light), by Clark and Gage, 1903).

\begin{tabular}{|c|c|c|c|c|c|c|c|c|c|}
\hline \multirow{2}{*}{$\begin{array}{l}\text { Time of } \\
\text { exposure } \\
\text { in } \\
\text { minutes }\end{array}$} & \multirow{2}{*}{$\begin{array}{c}\text { Number } \\
\text { of } \\
\text { survivors }\end{array}$} & \multicolumn{2}{|c|}{$\begin{array}{l}\text { Mortality per } \\
\text { time interval }\end{array}$} & \multirow{2}{*}{$\frac{1}{t} \log \frac{a}{a-x}$} & \multirow{2}{*}{$\begin{array}{l}\text { Time of } \\
\text { exposure } \\
\text { in } \\
\text { minutes }\end{array}$} & \multirow{2}{*}{$\begin{array}{c}\text { Number } \\
\text { of } \\
\text { survivors }\end{array}$} & \multicolumn{2}{|c|}{$\begin{array}{l}\text { Mortality per } \\
\text { time interval }\end{array}$} & \multirow{2}{*}{$\frac{1}{t} \log \frac{a}{a-x}$} \\
\hline & & $\begin{array}{l}\text { Indiv- } \\
\text { iduals }\end{array}$ & $\begin{array}{c}\text { dead in } \\
\text { survivors }\end{array}$ & & & & $\begin{array}{l}\text { Indiv- } \\
\text { iduals }\end{array}$ & $\begin{array}{c}\text { dead in } \\
\% \text { of } \\
\text { survivors }\end{array}$ & \\
\hline
\end{tabular}

Death by heat

\begin{tabular}{l}
\hline \multicolumn{1}{c||}{ Fruitflies exposed to $39.5^{\circ} \mathrm{C}$} \\
\hline \\
\hline
\end{tabular}

Death by poisons

\begin{tabular}{|c|c|c|c|c|c|c|c|c|c|}
\hline \multicolumn{5}{|c|}{ Mustard seeds in $0.2 \%_{0} \mathrm{HgCl}_{2}$} & \multicolumn{5}{|c|}{ Bacterium paratyphosum in $0.6 \%$ phenol } \\
\hline $\begin{array}{r}0 \\
30 \\
45 \\
60 \\
75 \\
90 \\
105 \\
120 \\
135\end{array}$ & $\begin{array}{c}1000 \\
940 \\
895.8 \\
790.6 \\
486.6 \\
220.6 \\
163.8 \\
146.0 \\
39.0\end{array}$ & $\begin{array}{r}60 \\
44.2 \\
105.2 \\
304.0 \\
266.0 \\
56.8 \\
17.8 \\
107.0\end{array}$ & $\begin{array}{r}3.0 \\
4.7 \\
11.7 \\
38.6 \\
54.8 \\
25.8 \\
11.0 \\
73.4\end{array}$ & $\begin{array}{l}0.0009 \\
0.0011 \\
0.0017 \\
0.0042 \\
0.0078 \\
0.0074 \\
0.0080 \\
0.0104\end{array}$ & $\begin{array}{r}0 \\
1 \\
2 \\
3 \\
4 \\
6 \\
9 \\
14 \\
19 \\
31\end{array}$ & $\begin{array}{r}100 \\
86.1 \\
75.2 \\
64.4 \\
60.5 \\
49.6 \\
29.4 \\
14.7 \\
9.2 \\
3.7\end{array}$ & $\begin{array}{r}13.9 \\
10.9 \\
10.8 \\
3.9 \\
6.0 \\
6.8 \\
3.3 \\
1.1 \\
0.5\end{array}$ & $\begin{array}{r}13.9 \\
12.7 \\
14.3 \\
6.1 \\
9.9 \\
13.7 \\
11.2 \\
7.5 \\
5.5\end{array}$ & $\begin{array}{l}0.065 \\
0.062 \\
0.060 \\
0.055 \\
0.051 \\
0.059 \\
0.060 \\
0.055 \\
0.046\end{array}$ \\
\hline
\end{tabular}

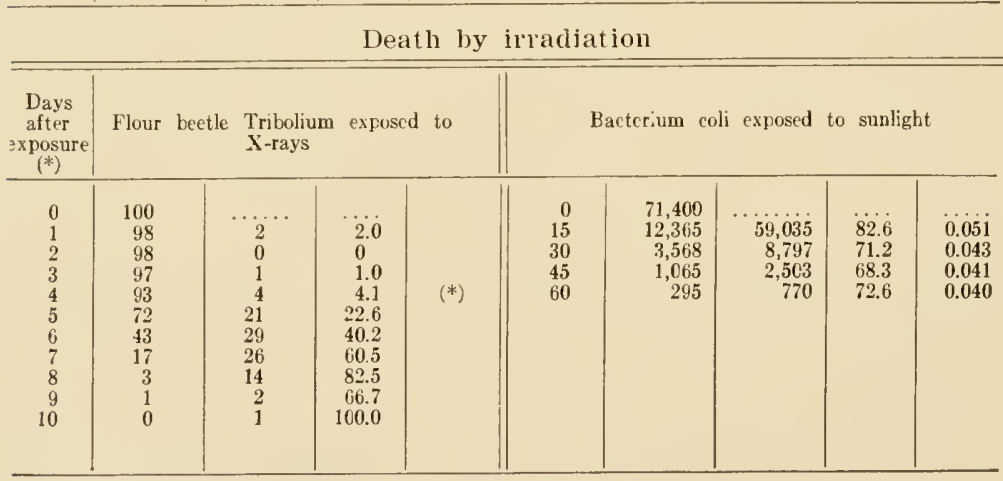

* See footnote on p. 20. 
TABLE 2

Order of death of three groups of bacteria representing three different degrees of resistance, and of a composite group resulting from a mixtmre of the former three (calculated values).

\begin{tabular}{|c|c|c|c|c|c|c|}
\hline \multirow[b]{2}{*}{ Death rate } & \multicolumn{3}{|c|}{$\begin{array}{l}\text { Number of survivors } \\
\text { in each group }\end{array}$} & \multicolumn{3}{|c|}{$\begin{array}{l}\text { Number of survivors } \\
\text { in the composite group }\end{array}$} \\
\hline & $90 \%$ & $50 \%$ & $10 \%$ & $\begin{array}{l}\text { Total n. of } \\
\text { survivors }\end{array}$ & $\begin{array}{c}\text { N. of surv. } \\
\text { per } 1000 \\
\text { cells }\end{array}$ & $\begin{array}{l}\text { Death } \\
\text { rate per } \\
\text { minute }\end{array}$ \\
\hline 0 minutes & 1000 & 1000 & 1000 & 3000 & & \\
\hline 1 minute & 100 & 500 & 900 & 1500 & 500 & \\
\hline 2 minutes & 10 & 250 & 810 & 1070 & 357 & $29 \%$ \\
\hline 3 minutes & 1 & 125 & 728 & 854 & 285 & $20 \%$ \\
\hline
\end{tabular}

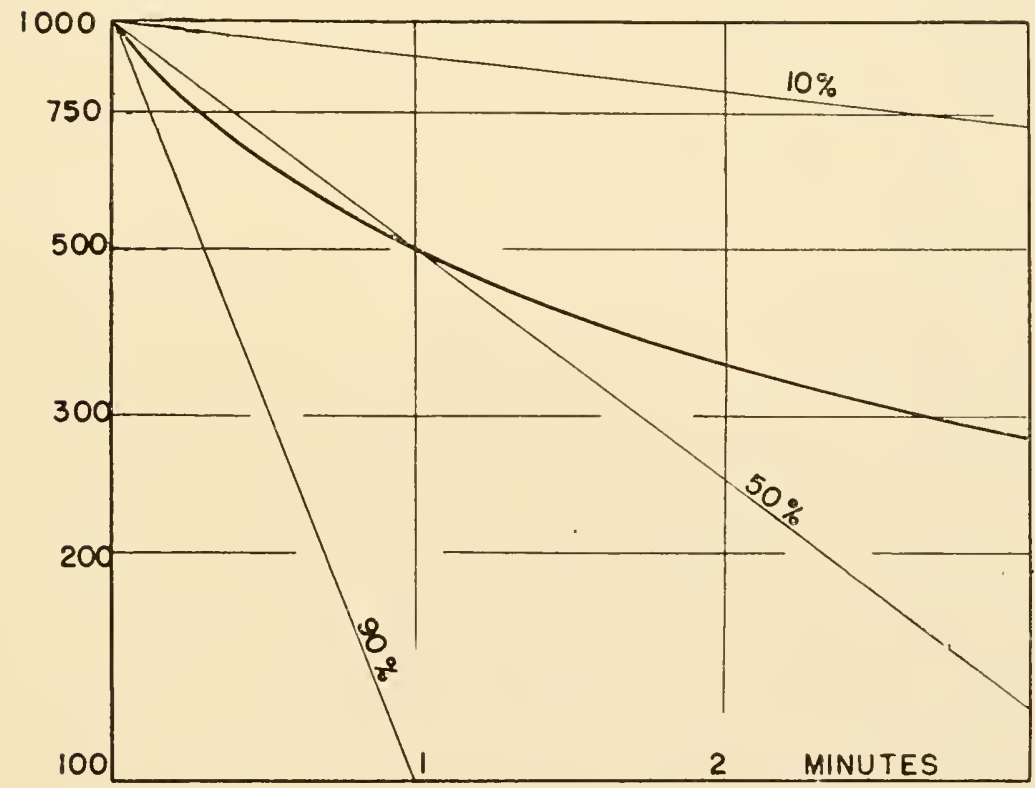

Fig. 3. Order of death of three groups of bacteria representing three different degrees of resistance (thin lines), and of a composite group resulting from the mixture of the former three (heavy line). Abscissa: time of exposure; ordinate: number of survivors per 1000, on logarithmic scale. 


\section{ORDER OF DEATH IN MULTICELLULAR VERSUS UNICELLULAR ORGANISMS}

The difference in the order of death between bacteria and higher organisms has occasionally been questioned.* A survey of all experiments on the order of death in bacteria until 1930 (Rahn, 1931) showed that 25\% of the curves resembled those of multicellular organisms, $21 \%$ were strictly rectilinear, and $54 \%$ were concave upward, like that of Figure 3 . Most of the $25 \%$ resembling multicellular organisms were actually obtained with "multicellular" bacteria, i.e., the bacteria were clustered as will be explained in more detail on p. 42. Since that survey a number of new investigations have verified the logarithmic order, e.g., the extensive investigations by Watkins and Winslow (1932), and by Beamer and Tammer (1939a and 1939b). Only two autlors, both working with chlorine, have obtained survivor eurves which are consistently concave downwards. It camnot be doubted any more that the majority of disinfectants, as well as heat and irradiation, result in an order of death in bacteria which is quite different from that of higher animals and plants.

The difference between bacteria and higher organisms which causes this difference in the order of death

\footnotetext{
*In the case of death by irradiation no mortality data comparable to those obtained with other killing agents conld be found in the literature for higher organisms. The order of death is frequently given in experiments with ultra-violet and X-rays, but the signification of these data is different from that of other experiments. Irradiated organisms appear normal for a long time after they bave received a lethal dose. The zero time for them is the moment when irradiation ceased, while, in all other experiments, it is the moment when exposure begins. If an insect, for example, does not die until a week after it received the lethal dose, it is clear that time-mortality curves mean very little.

This point is important in the study of the ultimate mechanism of death. Evidently, if a plant or animal survives for days after it has received a lethal dose, it is not the destruction of its enzymes and cytoplasm which is responsible for its death. Yet, the organism dies. Some irreparable damage has been done to some cell function which is not immediately needed. The similarity of this phenomenon with the fact that irradiated gonads often produce normal-appearing animals which, however, are sterile, suggests that death by irradiation is due to the inactivation of some genes.
} 
is a most obvious one: with bacteria, the individual is dead when a single cell dies; with higher organisms, the death of one cell does not kill the organism. It is not known how many cells of any tissue must be killed to cause, e.g., the death of a tadpole or an insect or a plant seed, but it is certain that no single cell is so all-important that its death causes the death of the entire organism.

The order of death of the individual cells in the tissues of higher plants or animals would be very difficult to ascertain because in most cases it is impossible to obtain cells of equal resistance and to expose them simultaneously. But it seems reasonable that the single cells of tissues should die like the single free-living cells.

Let us now investigate the order of death by heat in a multicellular organism, such as a tadpole, assuming that there is in that animal a vital organ, for example, the brain, which is most sensitive to heat. The surviror' curve of the individual brain cells would be

a $\quad$ a $\frac{s}{100} \quad a\left(\frac{s}{100}\right)^{2} \quad a\left(\frac{s}{100}\right)^{3} \cdots a\left(\frac{s}{100}\right)^{t}$

The probability that a certain definite cell in the brain is still alive after $t$ time units is

$$
p=\left(\frac{s}{100}\right)^{t}
$$

and the probability that it is dead is

$$
\mathrm{P}=1-\left(\frac{\mathrm{s}}{100}\right)^{\mathrm{t}}
$$

Since $s / 100$ is smaller than $1,(s / 100)^{t}$ decreases rapidly with longer exposure times. Therefore, the probability that this one cell is dead increases rapidly with prolonged exposure.

The probability of death of another definite brain cell is the same. The probability that both these cells are dead at the time $t$ is

$$
\mathrm{P}_{2}=\mathrm{P}_{1} \cdot \mathrm{P}_{1}=\left[1-\left(\frac{\mathrm{s}}{100}\right)^{\mathrm{t}}\right]^{2}
$$


and the probability that $n$ cells are dead is

$$
P_{n}=\left[1-\left(\frac{s}{100}\right)^{t}\right]^{n}
$$

If the tadpole is dead when $n$ brain cells are dead, $P n$ expresses the probability of its death, or the fraction of the total number of animals which is dead at the time $t$. If we multiply this probability by 100 , we obtain the percentage of dead tadpoles at the time $t$.

The entire difference of order of death is explained by this equation. Table 3 shows, on the basis of calculated values, how the mortality and the order of death vary when the number of cells whose inactivation

TABLE 3

Mortality (number dying per minute) in a population of 100 multicellular organisms, calculated on the assumption that an individual dies when $n$ of its cells are inactivated.

\begin{tabular}{|c|c|c|c|c|c|c|c|}
\hline $\mathrm{n}=$ & 1 & 2 & 5 & 10 & 50 & 100 & 500 \\
\hline \multicolumn{8}{|c|}{ If $90 \%$ of the cells die per minute (the survival rate being $10 \%$ ) } \\
\hline $\begin{array}{l}\text { 1st minute..... } \\
\text { 2nd minute..... } \\
\text { 3rd minute..... } \\
\text { 4th minute.... } \\
5 \text { th minute.... }\end{array}$ & $\begin{array}{r}90.00 \\
9.00 \\
0.90 \\
0.09 \\
0.01\end{array}$ & $\begin{array}{r}81.00 \\
17.01 \\
1.79 \\
0.18 \\
0.02\end{array}$ & $\begin{array}{r}59.05 \\
36.05 \\
4.40 \\
0.45 \\
0.05\end{array}$ & $\begin{array}{r}34.87 \\
55.56 \\
8.57 \\
0.90 \\
0.09\end{array}$ & $\begin{array}{r}0.52 \\
59.98 \\
34.62 \\
4.38 \\
0.45\end{array}$ & $\begin{array}{r}0 \\
36.60 \\
52.78 \\
9.62 \\
0.90\end{array}$ & $\begin{array}{r}0 \\
0.64 \\
59.96 \\
34.57 \\
4.33\end{array}$ \\
\hline \multicolumn{8}{|c|}{ If $80 \%$ of the cells die per minute (the survival rate being $20 \%$ ) } \\
\hline $\begin{array}{l}\text { 1st minute.... } \\
\text { 2nd minute.... } \\
\text { 3rd minute.... } \\
\text { 4th minute.... } \\
\text { 5th minute.... } \\
\text { 6th minute.... } \\
\text { 7th minute.... }\end{array}$ & $\begin{array}{r}80.00 \\
16.00 \\
3.20 \\
0.64 \\
0.13 \\
0.02 \\
0.01\end{array}$ & $\begin{array}{r}64.00 \\
28.16 \\
6.24 \\
1.28 \\
0.28 \\
0.03 \\
0.01\end{array}$ & $\begin{array}{r}32.77 \\
48.77 \\
14.52 \\
3.14 \\
0.64 \\
0.13 \\
0.02\end{array}$ & $\begin{array}{r}10.74 \\
55.75 \\
25.79 \\
6.13 \\
1.27 \\
0.26 \\
0.05\end{array}$ & $\begin{array}{r}0 \\
13.00 \\
53.93 \\
25.38 \\
6.12 \\
1.26 \\
0.25\end{array}$ & $\begin{array}{r}0 \\
1.69 \\
43.11 \\
40.42 \\
11.66 \\
2.49 \\
0.50\end{array}$ & $\begin{array}{l}0 \\
0 \\
1.80 \\
43.13 \\
40.42 \\
11.50 \\
2.52\end{array}$ \\
\hline \multicolumn{8}{|c|}{ If $70 \%$ of the cells die per minute (the survival rate being $30 \%$ ) } \\
\hline $\begin{array}{l}\text { 1st minute... } \\
\text { 2nd minute... } \\
\text { 3rd minute... } \\
\text { 4th minute... } \\
\text { 5th minute... } \\
6 \text { th minute... } \\
7 \text { th minute... } \\
\text { 8th minute.. } \\
\text { 9th minute.. }\end{array}$ & $\begin{array}{r}70.00 \\
21.00 \\
6.30 \\
1.89 \\
0.56 \\
0.17 \\
0.05 \\
0.02 \\
0.01\end{array}$ & $\begin{array}{r}33.81 \\
11.87 \\
3.72 \\
1.12 \\
0.33 \\
0.11 \\
0.03 \\
0.01\end{array}$ & $\begin{array}{r}16.81 \\
45.60 \\
24.79 \\
8.82 \\
2.77 \\
0.84 \\
0.26 \\
0.08 \\
0.02\end{array}$ & $\begin{array}{r}2.82 \\
36.12 \\
37.12 \\
16.13 \\
5.41 \\
1.67 \\
0.51 \\
0.16 \\
0.04\end{array}$ & \begin{tabular}{r}
\multicolumn{1}{c}{0} \\
0.90 \\
24.51 \\
41.19 \\
21.94 \\
7.87 \\
2.50 \\
0.77 \\
0.22
\end{tabular} & $\begin{array}{l}0 \\
0 \\
6.48 \\
37.87 \\
34.05 \\
14.55 \\
4.87 \\
1.55 \\
0.43\end{array}$ & $\begin{array}{l}0 \\
0 \\
0 \\
1.71 \\
27.91 \\
39.73 \\
20.20 \\
7.28 \\
2.15\end{array}$ \\
\hline
\end{tabular}


causes the death of the organism varies from 1 to 500 . The calculation is carried out for survival rates of $10 \%$, $20 \%$ and $30 \%$. Table 4 shows the gradual decrease in the number of survirors, for a survival rate of $50 \%$. In Table 6 the percentages of surrivors are compared when the death of $n$ definite, or that of $n$ random cells kills the organism.

Figure 4 gives the mortality curres and Fig. 5, the survivor curves on semi-logarithmic scale, for various values of $n$, and for a survival rate of $50 \%$. When $n=$ 1 , the mortality curve as well as the survivor curve are plainly those of bacteria. As $n$ increases, the curves become more and more similar to those characteristic of higher organisms, and for $n=8$ or more, they are practically identical with them.

Thus, the two different orders do not involve differences in the chemical dynamies of death; they are merely different results of the same principle at different levels of organization. As death of one single cell does not kill a large animal or plant, the organism survives until enough cells are inactivated to cause

TABLE 4

Nrmber of survivors in a poptrlation of 100 multicellular organisms, calculated on the assumption that an individual dies when $n$ of its cells are inactivated, and that the death rate of the cells is $50 \%$ per minute.

\begin{tabular}{c|r|r|r|r|r|r|r|r|r}
\hline $\mathrm{n}=$ & 1 & 2 & 4 & 8 & 16 & 32 & 64 & 128 & 1000 \\
\hline Minutes: & & & & & & & & & \\
1 & 50.00 & 75.00 & 93.75 & 99.61 & 100.00 & 100.00 & 100.00 & 100.00 & 100.00 \\
2 & 25.00 & 43.75 & 68.61 & 89.99 & 99.00 & 99.99 & 100.00 & 100.00 & 100.00 \\
3 & 12.50 & 23.44 & 41.63 & 65.64 & 88.19 & 98.61 & 99.99 & 100.00 & 100.00 \\
4 & 6.25 & 12.11 & 23.00 & 40.33 & 64.39 & 87.32 & 98.39 & 99.97 & 100.00 \\
5 & 3.12 & 6.15 & 12.18 & 22.43 & 39.83 & 63.80 & 86.89 & 98.28 & 100.00 \\
6 & 1.56 & 3.10 & 6.10 & 11.84 & 22.27 & 39.59 & 63.50 & 86.68 & 100.00 \\
7 & 0.78 & 1.56 & 3.09 & 6.08 & 11.80 & 22.20 & 39.47 & 63.37 & 99.96 \\
8 & 0.39 & 0.78 & 1.55 & 3.08 & 6.07 & 11.77 & 22.16 & 39.41 & 98.00 \\
9 & 0.20 & 0.39 & 0.79 & 1.55 & 3.08 & 6.06 & 11.76 & 22.14 & 85.84 \\
10 & 0.10 & 0.20 & 0.39 & 0.78 & 1.55 & 3.08 & 6.06 & 11.77 & 62.40 \\
11 & 0.05 & 0.10 & 0.20 & 0.39 & 0.78 & 1.55 & 3.07 & 6.06 & 38.60 \\
12 & 0.02 & 0.05 & 0.10 & 0.19 & 0.39 & 0.77 & 1.54 & 3.05 & 21.40 \\
13 & 0.01 & 0.03 & 0.05 & 0.10 & 0.19 & 0.39 & 0.77 & 1.54 & 11.40 \\
14 & 0 & 0.01 & 0.03 & 0.05 & 0.10 & 0.19 & 0.39 & 0.77 & 6.00 \\
15 & 0 & 0 & 0.01 & 0.03 & 0.05 & 0.10 & 0.20 & 0.39 & 3.02 \\
& & & & & & & & & \\
\hline
\end{tabular}


death. The different order is merely due to the fact that higher organisms are multicellular.

These tables and figures disclose another point which, if not very obvious, is quite important. The assumption made at the begimning of the calculations was that the cells die in logarithmic order. This implies that they are of uniform resistance. On the other hand, there can hardly be any doubt that, in any large population, all

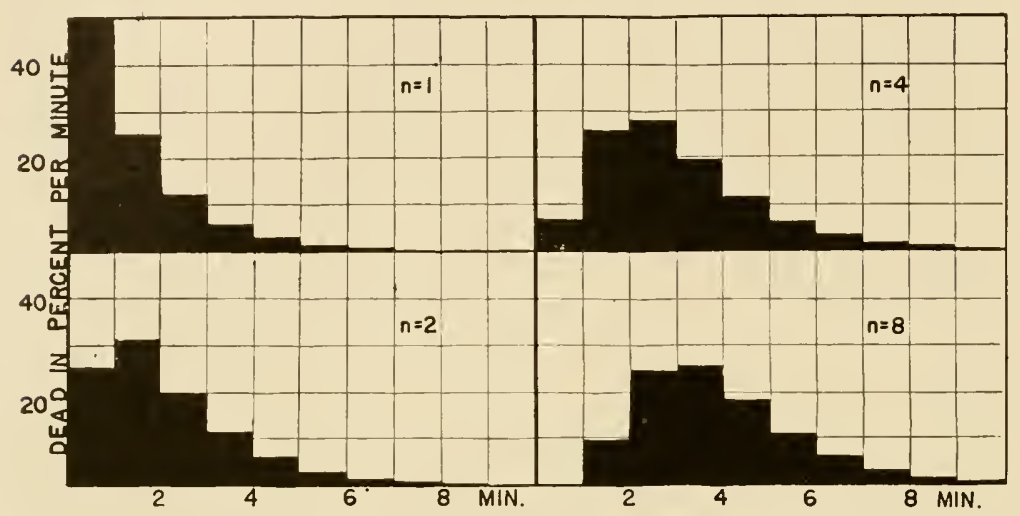

Fig. 4. Mortality curves (deaths per minute) of multicellular organisms the death of which is caused by the inactivation of $n$ cells.

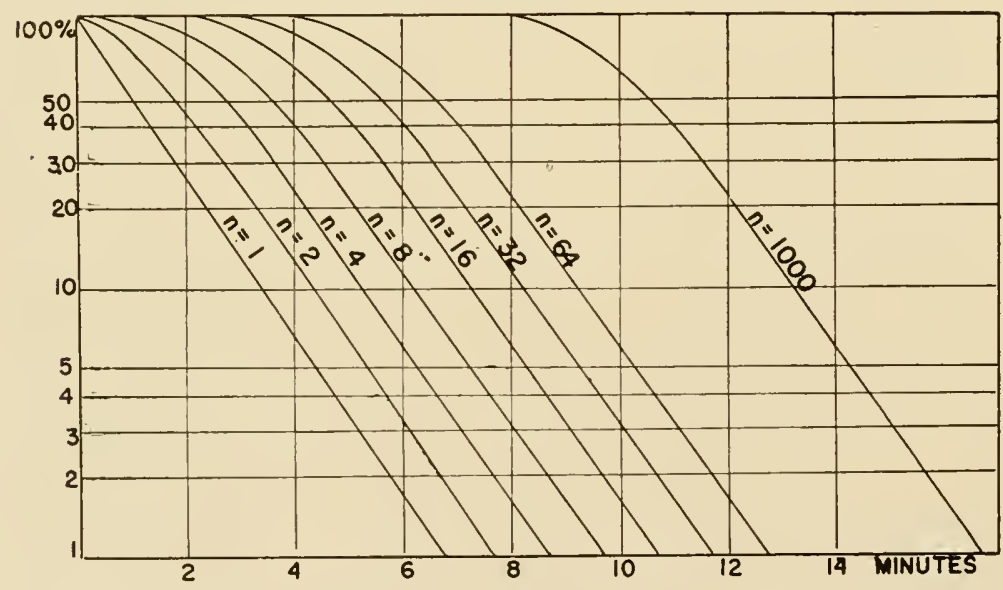

Fig. 5. Semi-logarithmic plot of the survivor curves of multicellular organisms the death of which is brought about by the destruction of $n$ cells. Abscissa: time of exposule; ordinate: per cent of survivors on a logarithmic scale. 
the cells are not of uniform resistance. Our assumption, then, seems to disagree with the facts. There is no contradiction, however, since the assumption does not deny the actual existence of a graded resistance, it merely states what is the consequence of a uniform resistance.

But there is a point where the theory of the logarithmic order of death is in direct contradiction with the theory which explains the mortality curves by a graded resistance. If the typical mortality curve of higher organisms, which is spread over a certain length of time, were due to a gradation in resistance, a uniform resistance should result in crowding the death of all individuals into the same instant. This last point is precisely what is contradicted by the theory of the logarithmic order.

To illustrate this point, let us assume a population of tadpoles killed by heat, where death occurs when $n=$ 100 brain cells are incapacitated. Three grades of resistance are assumed to be present, characterized by surrival rates of $10 \%, 20 \%$ and $30 \%$, respectively; the population consists of 100 individuals of each grade. Table 3 and Table 5 give the mortality for each grade and Table 5 gives also the mortality for the entire population. Figure 6 illustrates the fact that tadpoles of the same resistance do not die at the same moment, and that the maximum mortality occurs later and later, as the resistance increases. The composite mortality curve for

TABLE 5

Calculated mortality curve of a population consisting of organisms of three groups of different resistance.

\begin{tabular}{|c|c|c|c|c|c|c|c|c|c|c|}
\hline \multirow{2}{*}{$\begin{array}{c}\text { Number } \\
\text { of } \\
\text { Individuals }\end{array}$} & \multirow{2}{*}{$\begin{array}{c}\text { Survival } \\
\text { rate per } \\
\text { minute }\end{array}$} & \multicolumn{9}{|c|}{ Number of individuals dying per minute } \\
\hline & & 1 st & 2nd & $3 \mathrm{rd}$ & 4 th & 5 th & 6 th & 7 th & 8 th & 9 th \\
\hline $\begin{array}{ll}\text { Group I: } & 100 \\
\text { Group II: } & 100 \\
\text { Group III: } & 100 \\
\text { Total: } & 300 \\
\text { Percentage }\end{array}$ & $\begin{array}{l}10 \% \\
20 \% \\
30 \% \\
\ldots \\
\ldots\end{array}$ & $\begin{array}{l}0 \\
0 \\
0 \\
0 \\
0\end{array}$ & $\mid \begin{array}{c}36.60 \\
1.69 \\
0 \\
38.29 \\
12.7\end{array}$ & $\begin{array}{r}52.78 \\
43.11 \\
6.48 \\
102.37 \\
34.1\end{array}$ & $\begin{array}{r}9.62 \\
40.42 \\
37.87 \\
87.91 \\
29.3\end{array}$ & $\begin{array}{l}0.90 \\
11.66 \\
34.05 \\
46.61 \\
15.5\end{array}$ & \begin{tabular}{|c|}
0 \\
2.49 \\
14.55 \\
17.04 \\
5.7
\end{tabular} & $\begin{array}{l}0 \\
0.50 \\
4.87 \\
5.37 \\
1.9\end{array}$ & $\begin{array}{l}0 \\
0 \\
1.55 \\
1.55 \\
0.5\end{array}$ & $\begin{array}{l}0 \\
0 \\
0.43 \\
0.43 \\
0.1\end{array}$ \\
\hline
\end{tabular}


the total population is still a regular mortality curve, drawn out over a longer time than the curves of each grade. If the time seale is reduced to one-half, as in Figure 6a, (which gives the mortalities: 12.7, 63.4, 21.2, 2.4 and 0.1 for successive 2-minute intervals) the shape of the curve is the trpical one. Curves and Tables show that it is not only the sensitive cells that die early, and not only the resistant ones that survive for the longest time; in both groups there is a small percentage of cells of different degrees of resistance.

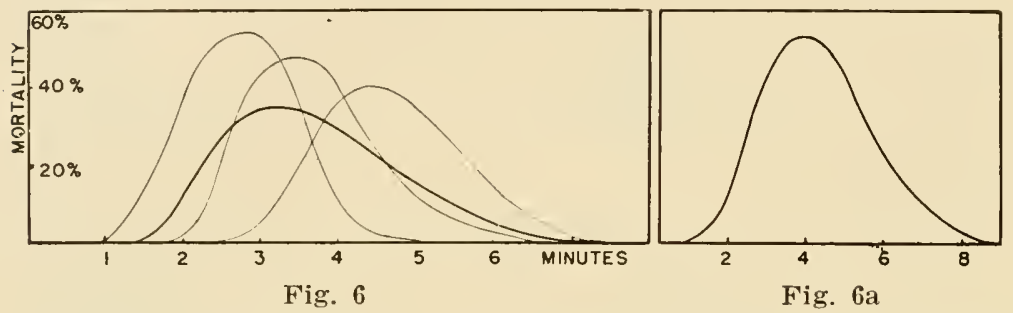

Fig. 6. Mortality curves of three groups of organisms representing different grades of resistance (thin lines) and of a population consisting of equal numbers from each of the three groups (heavy line).

Fig. 6a. Curve of the composite population of Fig. 6 on a reduced time scale.

TABLE 6

Number of survivors in a population of 100 organisms, calculated on the assumption that the death of $n$ out of 10 cells kills one organism.

Comparison of $n$ definite versus $n$ random cells. The survival rate of the cells is assumed to be $90 \%$ per minute.

\begin{tabular}{c|c|c|c|c|c|c|c|c|c}
\hline \multicolumn{7}{c}{ In the case of $n$ definite cells } \\
\hline \multirow{2}{*}{ Minutes } & $\mathrm{n}=1$ & $\mathrm{n}=2$ & $\mathrm{n}=3$ & $\mathrm{n}=4$ & $\mathrm{n}=5$ & $\mathrm{n}=6$ & $\mathrm{n}=7$ & $\mathrm{n}=8$ & $\mathrm{n}=9$ \\
& & & & & & & & & \\
\hline & & & & & & & & & \\
1 & 90 & 99.0 & 99.9 & 100 & 100 & 100 & 100 & 100 & 100 \\
2 & 81 & 96.4 & 99.3 & 99.9 & 100 & 100 & 100 & 100 & 100 \\
3 & 72.9 & 92.2 & 97.8 & 99.4 & 99.9 & 100 & 100 & 100 & 100 \\
5 & 65.6 & 86.3 & 94.9 & 98.1 & 99.3 & 99.8 & 99.1 & 100 & 100 \\
5 & 59.0 & 78.8 & 90.2 & 95.5 & 97.9 & 99.1 & 99.5 & 99.8 & 99.9 \\
\hline
\end{tabular}

In the case of $n$ random cells

\begin{tabular}{l|l|l|l|l|l|l|l|l|l}
\hline & & & & & & & & & \\
1 & 0 & 55 & 88 & 97.9 & 100 & 100 & 100 & 100 & 100 \\
2 & 0 & 0 & 18 & 71.8 & 93.7 & 99.0 & 100 & 100 & 100 \\
3 & 0 & 0 & 0 & 0 & 56.6 & 89.9 & 98.4 & 99.8 & 100 \\
4 & 0 & 0 & 0 & 0 & 0 & 46.0 & 88.5 & 98.4 & 99.9 \\
5 & 0 & 0 & 0 & 0 & 0 & 0 & 42.5 & 90.9 & 99.0 \\
\hline
\end{tabular}


The above calculation has been made on the assumption that we were dealing with "definite" cells, while death of the multicellular organism will result from the destruction of any "random" cells. The inactivation of $n$ definite cells will take much more time than the inactivation of $n$ random cells. The correction factor, which changes the formula for definite to that for random cells is

$$
\frac{a !}{(a-n) ! n !}
$$

The probability that any $u$ cells out of a total of $a$ cells are inactivated, is then (sce p. 21)

$$
P_{n}^{\prime}=\frac{a !}{(a-n) ! n !}\left[1-\left(\frac{s}{100}\right)^{t}\right]^{n}
$$

With $a=10$ cells, the probability that any one of these 10 cells dies is 10 times greater than the probability that a definite cell, e.g., Number 3, dies. The probability of death for any two cells is

$$
\frac{10 \cdot 9 \cdot 8 \cdot 7 \cdot 6 \cdot 5 \cdot 4 \cdot 3 \cdot 2 \cdot 1}{8 \cdot 7 \cdot 6 \cdot 5 \cdot 4 \cdot 3 \cdot 2 \cdot 1 \times 2 \cdot 1}
$$

or 45 times as great as for any two definite cells. Table 6 gives the number of survivors in the case of definite and of random cells for a survival rate of $90 \%$.

Generally speaking, since

$$
\frac{a !}{(a-n) ! n !}
$$

is a constant, it camnot alter the shape of the survivor curves or of the mortality curves. The rate is greatly increased, but only by a constant factor; the convex curves remain convex, and the straight lines remain straight. If more than one cell must become inactivated to cause the death of an organism, the order of death is not logarithmic, whether these cells are definite ones or not. 
III. THE CAUSE OF THE LOGARITHMIC ORDER OF DEATH

The Deathrate Constaut. The outstanding feature of the death of bacteria is the constancy of the deathrate. "Constant deathrate" means that the number of bacteria which die per time unit is a constant percentage of the number of living cells at the beginning of this time unit. (One may notice that the number of bacteria dying in each of the successive time units decreases continuously when the percentage in question remains constant.) The constancy of the death rate leads to the geometrical progression mentioned above (p. 16) for the sucessive number of survivors:

a $\quad a \frac{s}{100} \quad a\left(\frac{s}{100}\right)^{2} \quad a\left(\frac{s}{100}\right)^{3} \cdots a\left(\frac{s}{100}\right)^{t}$

where $a$ is the initial number and $s$ the percentage of survivors. After $t$ time units, the number of survivors is

$$
\mathrm{b}=\mathrm{a}\left(\frac{\mathrm{s}}{100}\right)^{\mathrm{t}}
$$

or

$$
\mathrm{t} \log \frac{\mathrm{s}}{100}=\log \mathrm{b}-\log \mathrm{a}
$$

In this equation, $s$ is constant, and therefore $\log \mathrm{s} / 100$ may be called $\mathrm{C}_{1}$; $a$ is also constant, and $\log a$ may be called $\mathrm{C}_{2} ; b$ is variable and is a function of the exposure time $t$. Thus, we have

$$
\log \mathrm{b}=\mathrm{C}_{1} \mathrm{t}+\mathrm{C}_{2}
$$

which means that the logarithms of the numbers of survivors plotted against the time of exposure lie on a straight line. 
It is inconvenient to express the rate of dying as the percentage of survivors or deaths per time unit since the time intervals may vary eren within one experiment. It has become customary to compute a constant, the "death rate constant," which is analogous to the reaction constant of chemical reactions. If, at the time $t, x$ bacteria out of a initial bacteria have died, the number of survivors is $a-x$, and the rate of death is

$$
\frac{d x}{d t}=k(a-x)
$$

which, upon integration, gives

$$
k=\frac{1}{t} \ln \frac{a}{a-x}
$$

The constancy of $k$ in this formula is frequently used as a criterion for the logarithmic order. But, for the purpose of testing the constancy of the $k$ values, it is customary to use decimal logarithms instead of natural logarithms as the equation requires. This gives rise to a new constant, which will be designated by $K$.

$$
\mathrm{K}=0.434 \mathrm{k}=\frac{1}{\mathrm{t}} \log \frac{\text { initial number }}{\text { survivors }}
$$

Tables 1 and 7 show that $K$ (and therefore $k$ ) increases with time in the case of multicellular organisms, but is constant or decreases in the case of bacteria.

The percentages of survivors per time unit can be found from the equation

$$
\begin{aligned}
& K=\log \frac{100}{S} \\
& \log S=2-K
\end{aligned}
$$

This substitution of decimal for natural logarithms may not be permissible if the constants are to be used for further mathematical calculations. 
The following table shows the relation between the deathrate constint $K$ and the percentage of bacteria killed per time unit, which is (100-s).

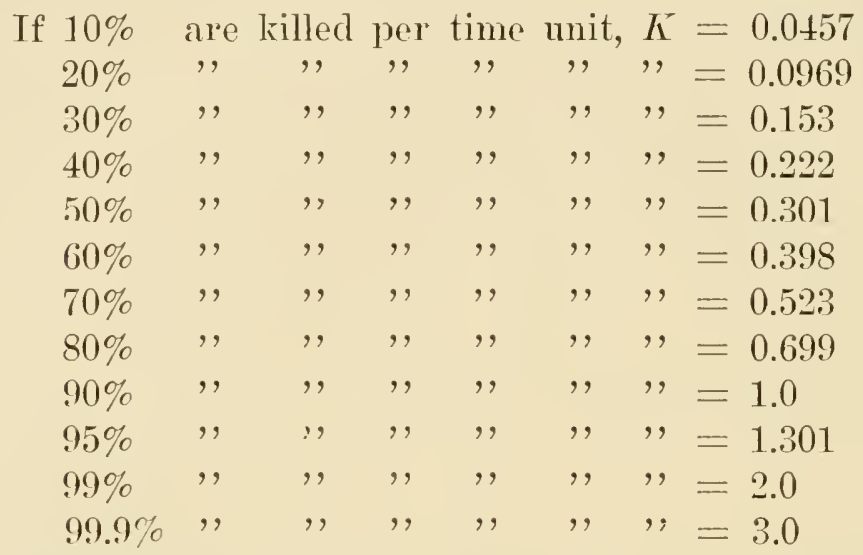

Santholzer and Katzin (1942) found a simple way of expressing the logarithmie relation in practical applications. They point out that, for a survival ratio of $10 \%$,

$$
\mathrm{Kt}=\log \frac{\mathrm{a}}{0.1 \mathrm{a}}=\log 10=1
$$

and therefore

$$
t=\frac{1}{K}
$$

Then, instead of speaking of deathrates or percentage of survivors, they nse as basis of all their caleulations this "decimal reduction time," i.e., the time necessary to reduce the bacterial population to one-tenth of its original value. It is obvious that a doubling of this time will reduce the number of bacteria to $1 \%$ of the initial number, and trebling would leave only 1 out of 1,000 cells alive. This terminology is applied to the pasteurization of milk. The decimal reduction time is more readily visnalized than the death rate. Generally speaking, death time is more commonly used in applied sterilization and disinfeetion than death rate. 
Explanations of the Logarithmic $O r d e r$. The striking difference between the mortality curves of bacteria and those of higher organisms has attracted the attention of many biologists. According to their attitude towards this problem, they can be divided into three groups. The first group denies the existence of a logarithmic order of death. They maintain that bacteria have the same type of survivor curve as higher organisms, but that the rapidity of bacterial death makes us overlook a first period of low mortality, which, though very short, would nevertheless be present. The second group accepts the logarithmic order as an experimental fact and claims that it is brought about by an unusual distribution of bacterial resistance; rarious biological reasons for this peculiar gradation of resistance are offered. The third group believes that variation in resistance is a minor issue, and that the logarithmic order must be explained by analogy to the monomolecular reactions of chemistry.

The attitude of the first group can be characterized by the following quotation from Loeb and Northrop (1917): "Miss Chick states that ... in each interval of time the same percentage of individuals alive at this time is killed. She was probably led to this assumption by the fact that the ascending branch of the mortality enrve in her experiments was generally very steep. The agencies used by her for killing the bacteria were so powerful that the ascending branch became almost a vertical line, thus escaping attention. Hence she noticed usually only the less steep descending branch which could be interpreted as a monomolecular curve for the reason that her experiments lasted only a short time."

Knaysi (1930, I-V) took up this general line of thought in five short papers. We are primarily concerned here with his experiments with weak disinfectants (paper II) which show a very slow decrease in the number of organisms for the first two minutes, and which resulted in 
curves that he considers sigmoid. Six of the experiments required 180 minutes; the shortest one lasted 52 minutes. This represents a slow death for disinfection experiments. It will be shown on p. 48 that a sigmoid survivor enrve must be expected when death is so slow that repair becomes appreciable.

After the first few minutes, Knaysi's curves are shaped quite differently from any surviror curves for higher organisms (plotted on semi-logarithmic scale). Five are concare upwards, indicating inlomogeneous material (probably due to the use of cells from agar cultures instead of from the customary liquid cultures), two are straight, and three are so irregular that they would not fit any theory. Knaysi concluded that "these results can be arlequately explained only if the distribution of resistance in cultures of bacteria is considered to govern the course of the process."

Knaysi later (paper $\mathrm{V}$ ) approached the problem mathematically by using Pearson's curres of variability. The curres shown in his graphs are quite different from any mortality curves known for higher organisms. He further quotes Tule who "demonstrated that if the cells are to be considered all alike, and if the action of poison is noncumulative, the law of chance gives an exponential surviror's' curve. If the action is cumulative, the death rate constantly increalses." Howerer, in Knaysi's experiments, the death rate increases only for a few minutes and then declines rapidly.

But the main point of the controversy is the shape of the mortality curves during the very first minutes of exposure. The determination of this shape is practically impossible becanse one camnot prove that, with bacteria, death begins at the moment of exposure, and because one can always argue that the bacteria which were found dead after the first minute, all died in the second half of this minute. Eren for the x-ray experiment of Figure 8 where the first observation was made 
after 6 seconds, it could be claimed that no cell died in the first 3 seconds. Though such a claim may be entirely unjustified, it is obviously impossible to disprove it.

But those who profess a constant death rate in bacteria can disprove the identity of the two orders of death by pointing to the surrivor curves. If the mortality curves of bacteria and those of higher organisms are essentially similar, the semilogarithmic graphs of the survivor curves of higher organisms should be straight lines when the first two or three survivor counts are omitted. A glance at Figure 2 will show that this is not the case.

Far more helpful ir one's decision as to the nature of the curve is the death rate constant $K$, because each value of $K$ is significant in itself independently of the previous or of the subsequent trend of the curve. It has been shown that, with higher organisms, (or with clustered bacteria, or also in the case of very slow death, as will be explained below) $K$ is not constant, but increases with time; that, with uniform bacteria, it is constant; and that, with bacteria of unequal resistance (e.g., with very young cultures), it decreases consistently. To illustrate these differences of death rate, a few characteristic data (where $K$ is multiplied by 1,000 for easier comparison) have been gathered in Table 7 . They represent many of the organisms commonly used in experiments on death. Each set gives the K-values for all successive time units for which survirors were counted.

Subsequent to the objections of Loeb and Northrop, of Knaysi and of many others, Watkins and Winslow (1932) made a rery extensive study of the order of death of Bacterium coli killed by heat and by dilute $\mathrm{NaOH}$. (For the complete 150 sets of data, see Watkins, 1932). They conchded: "The studies... seem to indicate that when regetative cells (Esch. coli) are exposed to the toxic action of sodium hydroxide, reduction proceeds at a generally logarithmic rate and does not ex- 
TABLE 7

Death rate constants at successive time intervals for various organisms killed by heat or by poisons. (The original values of the death rate constants $K$ are multiplied by 1000.)

\begin{tabular}{|c|c|c|c|}
\hline \multirow{2}{*}{$\begin{array}{c}\text { Higher } \\
\text { organisms }\end{array}$} & \multicolumn{3}{|c|}{ Bacteria and Yeasts } \\
\hline & Clustered & Single, uniform & Single, mixed \\
\hline
\end{tabular}

Death by heat

\begin{tabular}{|c|c|c|c|c|c|c|c|c|c|}
\hline $\begin{array}{c}\text { Fruit- } \\
\text { Flies }\end{array}$ & Tadpoles & $\begin{array}{l}\text { Wheat } \\
\text { Seeds }\end{array}$ & $\begin{array}{l}\text { Staph. } \\
\text { aureus }\end{array}$ & $\begin{array}{l}\text { Microc. } \\
\text { sulfureus }\end{array}$ & $\begin{array}{c}\text { Bacter. } \\
\text { coli }\end{array}$ & $\begin{array}{l}\text { Sacchar. } \\
\text { ellips- } \\
\text { oideus }\end{array}$ & $\begin{array}{c}\text { Bacter. } \\
\text { para- } \\
\text { typhosum }\end{array}$ & $\begin{array}{c}\text { Bacter. } \\
\text { para- } \\
\text { typhosum }\end{array}$ & $\begin{array}{l}\text { Strept. } \\
\text { lactis }\end{array}$ \\
\hline $\begin{array}{c}0 \\
0 \\
0 \\
0 \\
4 \\
13 \\
26 \\
43 \\
61 \\
77 \\
84 \\
88 \\
123 \\
140 \\
167 \\
\text { Loeb and } \\
\text { Northrop, } \\
1917\end{array}$ & $\begin{array}{c}0 \\
2 \\
25 \\
67 \\
150 \\
\ldots \\
\ldots \\
\ldots \\
\ldots \\
\ldots \\
\ldots \\
\ldots \\
\ldots \\
\ldots \\
\text { Boyeott, } \\
1920\end{array}$ & $\begin{array}{r}0 \\
0 \\
0 \\
0 \\
0 \\
0 \\
17 \\
27 \\
46 \\
95 \\
117 \\
141 \\
\ldots \ldots \\
\ldots \ldots \\
\text { Groves, } \\
1917\end{array}$ & $\begin{array}{c}165 \\
176 \\
223 \\
380 \\
\ldots \\
\ldots \ldots \\
\ldots \ldots \\
\ldots \ldots \\
\ldots \ldots \\
\ldots \ldots \\
\ldots \ldots \\
\ldots \ldots \\
\ldots \ldots \\
\ldots \cdots \\
\text { click } \\
1910\end{array}$ & $\begin{array}{c}103 \\
177 \\
139 \\
267 \\
484 \\
458 \\
405 \\
336 \\
407 \\
\ldots \ldots \\
\ldots \ldots \\
\ldots \ldots \\
\ldots \ldots \\
\text { Satticr } \\
1928\end{array}$ & $\begin{array}{r}82 \\
83 \\
87 \\
102 \\
85 \\
89 \\
\ldots \ldots \\
\ldots \ldots \\
\ldots . \\
\ldots \ldots \\
\ldots \ldots \\
\ldots \ldots \\
\ldots \ldots \\
\text { Click } \\
1910\end{array}$ & \begin{tabular}{|c|}
32 \\
30 \\
36 \\
37 \\
39 \\
35 \\
34 \\
32 \\
$\ldots$ \\
$\ldots$ \\
$\ldots$ \\
$\ldots$ \\
$\ldots$ \\
$\ldots$ \\
Beamer \\
and \\
Tanner, \\
1938
\end{tabular} & $\begin{array}{c}63 \\
68 \\
76 \\
77 \\
76 \\
74 \\
68 \\
65 \\
65 \\
\ldots . \\
\ldots . \\
\ldots . \\
\text { Age } \\
55 \text { hours } \\
\text { Reichen- } \\
\text { bach, } \\
\text { 1911 }\end{array}$ & $\begin{array}{c}748 \\
355 \\
222 \\
166 \\
133 \\
113 \\
107 \\
\ldots . \\
\ldots \ldots \\
\ldots \ldots \\
\ldots . \\
\ldots . \\
\text { Age } \\
5 \text { hours } \\
\text { Rejehen- } \\
\text { hach, } \\
\text { 1911 }\end{array}$ & $\begin{array}{c}4431 \\
5210 \\
4495 \\
3335 \\
2412 \\
2229 \\
1851 \\
\ldots . \\
\ldots \\
\ldots . \\
\ldots . \\
\ldots . \\
\ldots \\
\ldots . \\
\text { Sattler, } \\
1928\end{array}$ \\
\hline
\end{tabular}

Death by poisons

\begin{tabular}{|c|c|c|c|c|c|c|c|c|c|}
\hline $\begin{array}{l}\text { Mustard } \\
\text { seeds, } \\
\mathrm{HgCl}_{2}\end{array}$ & $\begin{array}{c}\text { Mosquito } \\
\text { larvac, } \\
\text { Heptylic } \\
\text { acid }\end{array}$ & $\begin{array}{l}\text { Tomato } \\
\text { moth } \\
\text { larvae, } \\
\text { lead } \\
\text { arsenate }\end{array}$ & $\begin{array}{l}\text { Bacilus } \\
\text { No. } 25, \\
\text { NaOH }\end{array}$ & $\underset{\mathrm{HgCillus}}{\mathrm{Hg}_{2}}$ & $\begin{array}{l}\text { Anthra. } \\
\text { sporcs, } \\
\mathrm{HgCl}_{2}\end{array}$ & $\begin{array}{l}\text { Bacter. } \\
\text { coli, } \\
\mathrm{NaOH}\end{array}$ & $\begin{array}{c}\text { Bacter. } \\
\text { coli, } \\
\mathrm{CaCl}\end{array}$ & $\begin{array}{c}\text { Bacter. } \\
\text { typhosum, } \\
\text { Phenol }\end{array}$ & $\begin{array}{l}\text { Bacter. } \\
\text { paratyph } \\
\text { Phenol }\end{array}$ \\
\hline 0 & 0 & 45 & 058 & 11 & 146 & 13 & 256 & 60 & 62 \\
\hline 1.8 & 0 & 73 & 0.58 & 74 & 126 & 9 & 220 & 67 & 56 \\
\hline 2.3 & 0 & 143 & 061 & 70 & 138 & 10 & 237 & 52 & 58 \\
\hline 5.2 & 0.3 & 171 & 068 & 82 & 149 & 9 & 213 & 59 & 46 \\
\hline 8.7 & 08 & 214 & 0.75 & 107 & 204 & 11 & $\ldots$ & 57 & 38 \\
\hline 8.7 & 1.5 & 472 & 086 & 106 & 186 & 13 & $\ldots$. & 5 & 33 \\
\hline 8.0 & 2.3 & 584 & 1.08 & 116 & 147 & 11 & & 58 & 32 \\
\hline 11.7 & 3.6 & 901 & $\ldots$ & $\ldots \ldots$ & $\ldots$ & 11 & & 57 & 30 \\
\hline$\ldots$ & 4. 7 & 2470 & & $\ldots$ & & . & & 55 & 23 \\
\hline$\ldots$ & 5.3 & $\ldots$ & $\ldots$ & $\ldots$ & & . & $\ldots$ & 56 & 22 \\
\hline$\ldots$ & 6.7 & $\ldots$ & $\ldots$ & $\ldots$ & & . & $\ldots$ & 56 & 20 \\
\hline 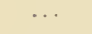 & $\begin{array}{l}8.9 \\
8.3\end{array}$ & $\ldots$ & $\cdots$ & & & & $\cdots$ & $\cdots$ & $\cdots$ \\
\hline $\begin{array}{c}\text { Hewlett, } \\
1909\end{array}$ & $\begin{array}{c}\text { O'Kane } \\
\text { ct al., } \\
\mathbf{1 9 3 4}\end{array}$ & $\begin{array}{l}\text { Lloyd } \\
1920\end{array}$ & $\begin{array}{c}\text { Myers, } \\
1929\end{array}$ & $\begin{array}{l}\text { Reich- } \\
\text { enbach, } \\
1911\end{array}$ & $\begin{array}{l}\text { Madsen } \\
\text { and } \\
\text { Nyman, } \\
1907\end{array}$ & $\begin{array}{c}\text { Watk ns, } \\
1932\end{array}$ & $\begin{array}{c}\text { Winslow } \\
\text { and Falk, } \\
1926\end{array}$ & $\begin{array}{c}\text { Lee and } \\
\text { Gilbert, } \\
1922\end{array}$ & $\begin{array}{l}\text { Chick, } \\
1908\end{array}$ \\
\hline
\end{tabular}

hibit the increasing mortality rate with the progress of time which has been observed by Levine and his associates for spores. In our experiments, values for $K$ (the coefficient for the rate of reduction per unit of time) 
were approximately constant throughout the experiment. We have estimated the ratio of $K$ for the two time-halves of an experiment and find this ratio to average 0.97 for 109 experinents with $\mathrm{XaOH}, 1.17$ for 16 experiments with a borate-buffer mixture and 0.96 for 26 experiments with hot water $\left(50^{\circ}\right.$ and $\left.55^{\circ}\right) . "$

The second group of explanations comes from biologists who accept the logarithmic order of death as an experimental fact and try to explain how the resistance is graded in a different way in bacteria and higher organisms. Reichenbach (1911) and Henderson Smith (1921) are the only authors who seem to have presented really original ideas on the subject.

Reichenbach assumed that, in a bacterial culture, a definite proportion of cells from each generation ceases to multiply and becomes increasingly more resistant during the ensuing rest period. Such a culture would exhibit an exponentially graded resistance. This assumption, it must be recognized, has no experimental foumdittion. However, it would lead to the same result to assume that the bacterial cell does not divide into two equal parts, but that the mother cell produces a daughter cell as in the case of yeasts, and that the mother cell is definitely older and more resistant than the daughter cell. This mode of multiplication would result in an exponentially graded resistance which under certain conditions could yield a perfect logarithmic order. But the theory, aside from its unrerified morphological implications, fails to explain the logarithmic order of death in the case of spores. It seems impossible that the assumed type of gradation of resistance could occur in the case of spores.

Henderson Snith (1921) points out that a variation in resistance may be brought about by differences in the thickness of the cell membranes. Penetration by poison may be proportional to the square of the thickness, and this would result in an order of death approximating the 
logarithmic. This explanation to which one may object again that it is entirely theoretical and not based upon any measurements of membrane thickness (see however Figure 12)-might explain chemical disinfection, but it does not seem plausible for heat sterilization, and can not explain the order of death in the case of X-rays which penetrate with lightning speed.

Lee and Gilbert (1918) call attention to the fact that biological characteristies are as a rule listributed in a manner quite different from that which has been assumed in the various theories of grarled resistance. "In view of these observations, the authors are led to the conclusion that the logarithmic nature of the disinfection process is due to a general similarity of the individuals in a given pure culture rather than to a dissimilarity of the individuals.",

The third group of explanations is based on the analogy with monomolecular chemical reactions. The all-inclusive statement by Paul (1909) that bacteria are so small that they react chemically like large colloidal molecules will probably not be taken seriously by the biologists of today.

More in line" with present conceptions is the explanation proposed by Isaacs (1935) who elaborated on the contention of many biologists that enzyme inactivation is probably the first step in the leath of the cell. The fact that enzyme inactivation is frequently a monomolecular process led Isaaes to the hasty conclusion that the logarithmic order of enzyme inactivation is the evident cause of the logarithmic order of death of bacteria.

This conclusion is based on a wrong application of the law of mass action. When an enzyme solution, distributed in 100 test tubes, is heated, and one of these tubes shows $90 \%$ of inactivated molecules, we are certain that all other test tubes at that moment also contain $90 \%$ of inactivated molecules. The order of enzyme inactivation in each test tube is logarithmic, and the reaction 
must necessarily be identical in all tubes, as long as the mass law applies. If, in identical test tubes, the reaction would proceed differently, there could be no mass law and no science of chemistry. Thus, if bacteria would die from inactivation of enzymes, all cells should die at the same moment.

The mass law makes only one assumption, namely, the presence of masses (i.e., of large numbers) of reacting molecules. This requirement is fulfilled in our case. Estimates by Hand (1933) for catalase in yeast suggest about 2,000 molecules per cell. Haldane and Stern (1932) concluded that the yeast cell contains between 15,000 and 150,000 invertase molecules. The assumption of fairly large numbers of enzyme molecules in bacteria, which are in many respects comparable with yeast, seems thus justified, and the logarithmic order of enzyme inactivation cannot explain the logarithmic order of death of bacteria.

Mass Law and Single Molecules. However, if the number of molecules becomes very small, identical cells would not die at the same time. The mass law can not be applied when there is no mass. When a million test tubes, each containing a solution of 1,000 enzyme molecules, are heated uniformly, it is quite certain that when half of the molecules are inactivated in one tube, the same fraction will be inactivated in all the other tubes. When the same solution is put in much smaller test tubes so that each contains only 10 enzyme molecules, it is to be expected that, while 5 molecules are inactivated in most of the tubes, there may be 4 or 6 inactivated in some of them. If we choose our tubes so small that each contains only one enzyme molecule, the reaction cannot be identical in all the tubes. Yet, the mass law still holds for the entire enzyme solution. By changing the size of the container, the rate of reaction cannot be altered, and, at the same time and temperature, half of the molecules must be inactivated in these small 
tubes. This means that, of these uniform test tubes under uniform conditions, one-half contains inactivated molecules and the other does not. It is possible to compute from the mass law the number of tubes in which a single protein molecule is inactivated, but it must be realized that the result represents only a probability and not a certainty. The certainty of the mass law is founded on the very large number of molecules present in ordinary chemical reactions. In living cells, not all kinds of molecules are so numerous.

If $\mathrm{p} \%$ of the molecules are inactivated per minute, the total of a tubes will be divided into those with an inactivated, and those with an unchanged molecule, as follows :

\begin{tabular}{|c|c|c|}
\hline $\begin{array}{l}\text { Time } \\
\text { in } \\
\text { min. }\end{array}$ & $\begin{array}{l}\text { Tubes with } \\
\text { unchanged } \\
\text { molecules }\end{array}$ & $\begin{array}{l}\text { Tubes with inactivated } \\
\text { molecules }\end{array}$ \\
\hline 0 & $\mathrm{a}$ & 0 \\
\hline 1 & $a\left(1-\frac{p}{100}\right)$ & $a \frac{p}{100}$ \\
\hline 2 & $a\left(1-\frac{p}{100}\right)^{2}$ & $a \frac{p}{100}+a\left(1-\frac{p}{100}\right) \frac{p}{100}$ \\
\hline 3 & $a\left(1-\frac{p}{100}\right)^{3}$ & $\begin{array}{r}a \frac{p}{100}+a \frac{p}{100}\left(1-\frac{p}{100}\right)+ \\
\quad a \frac{p}{100}\left(1-\frac{p}{100}\right)^{2}\end{array}$ \\
\hline $\mathrm{t}$ & $a\left(1-\frac{p}{100}\right)^{t}$ & $\mathrm{a}\left[1-\left(1-\frac{\mathrm{p}}{100}\right)^{\mathrm{t}}\right]$ \\
\hline
\end{tabular}


The probability that a certain tube (or molecule) has undergone a change at the time $t$ is

$$
\mathrm{P}_{1}=1-\left(1-\frac{\mathrm{p}}{100}\right)^{\mathrm{t}}
$$

This formula for the probability of inactivation applies to any one definite enzyme molecule, whether in a separate small test tube or in the original large volume of enzyme solution. The probability that two definite molecules, either in the large rolume or in the small test tube, be inactivated is the product of the probabilities of each separate event:

$$
\mathrm{P}_{2}=\mathrm{P}_{1} \cdot \mathrm{P}_{1}=\left[1-\left(1-\frac{\mathrm{p}}{100}\right)^{\mathrm{t}}\right]^{2}
$$

and the probability that $n$ molecules be inactivated is

$$
{ }^{\mathrm{e}} \mathrm{P}_{\mathrm{n}}=\left[1-\left(1-\frac{p}{100}\right)^{\mathrm{t}}\right]^{\mathrm{n}}
$$

As was stated above, $p$ is the percentage of molecules inactivated per minute. The percentage not changed is $100-p=s$. If we introduce this into the above equation, we obtain

$$
P_{n}=\left[1-\left(\frac{s}{100}\right)^{t}\right]^{n}
$$

This is the same formula which we encountered on page 2.. All calculations in Tables 3 and 4 , and the curves of Figures 4 and 5 apply to this case; we merely have to substitute the word "molecule" for "cell."

The conclusion is that a logarithmic order of death can be obtained only if the death of the bacterium is brought about by the reaction of one single molecule. This conclusion is absolute. The logarithmic order of death is entirely impossible if more than one molecule must be inactirated to produce the death of the cell. As Tables 3 and 4 and Figure 4 show, an approximation of the logasithmic order is obtained if death is cansed by inactiva- 
tion of a very few molecules but if this number is higher than 4 or 5 , the order is very definitely not logarithmic. This eliminates denaturation of enzymes or of the cytoplasm as the cause of death, wherever the logarithmic order prevails, because it does not seem possible that inactivation of a very few of the numerous identical molecules can kill the organism. It would probably exclude also the disruption of the cell membrane as a cause of death, for this is likely to require inactivation of a considerable number of molecules before damage becomes irreparable.

Let us now consider the bacteriologist's definition of death: a bacterium is dead when it has lost the power to reproduce. Cell division is linked with chromsome division, the chromsomes contain the genes, and the inactivation of certain genes is known to cause "lethal mutations," i.e., to prevent the cell from multiplying. While chromsomes and genes have not been definitely found in bacteria, these organisms undoubtedly have some hereditary mechanism, and hereditary units. As a rale, there are two genes of the same kind in a diploid cell, and one in a haploid cell. According to Fricke and Demerec (1937): "we may assume that a gene contains about 2500 atoms . . This would indicate an average gene diameter of about 25 A." This is the size of a quite small protein molecule. A gene, then, would consist of only one or two molecules. Each gene is different from all others, and has its own rate of denaturation. If one vitally essential gene is denatured, and the cell can no longer divide, the bacterium is sterile, that is, dead, according to the bacteriological definition.

This explanation, namely, that "death" of bacteria is brought about by the inactivation of a gene (Rahn, 1929, 1934 ) is correct only for the bacteriologist's definition of death. Jordan (1940) defined the death of bacteria as "lethal mutation." The very extensive data on mutations brought about by $\mathrm{X}$-rays, and on the lethal ef- 
fects of X-rays, all point very definitely to the fact that the genes are the most sensitive part of the cell. Frequently, while no other effects of irradiation are immediately noticeable on the irradiated plants or animals, sterility has been induced, or, when the affected gene's are less essential, the offspring is abnormal in some way.

To this mass of indirect evidence has recently been added the chemical production of mutants in fungi. Thom and Steinberg (1939) obtained stable mutants of several Aspergilli by making the spores germinate on agar containing $\mathrm{KNO}_{2}$. All mutations consisted in the loss of some activity related to the reproductive function, and have been explained by the anthors as being caused by inactivation of some amino groups in one of the genes.

Analogons findings have been recorded in bacteria. Penfold (1911) grew Bacterium coli on agar containing chloracetate; among the few bacteria that survived, were some which had permanently lost the power to produce gas from glucose. Revis 11912) obtained the same result with malachite green and brilliant green. Lommel (1926), by means of weak disinfectants, produced a variant of Bacterium coli which had lost the ability to ferment lactose. Unpigmented "albino" strains of Bacterium prodigiosum can be obtained by cultiration at rery high temperature. All the mutations cited were irreversible. If, in bacteria and fungi, weak disinfectants can permanently inactivate some genes, which control fermentation, reproduction or pigmentation, it is highly probable that, in general, they cause changes in genes necessary for life and thereby produce sterile mutants, which the bacteriologist would consider dead. 


\section{CONDITIONS RESULTING IN A NON-LOGARITHMIC} ORDER OF DEATH

Cell Clusters and Chain Formation. The logarithmic order of death of bacteria can be established only by counting the survivors, and the only practical method in use is the plate count method which gives the number of colonies developing from a known volume of bacterial suspension. The number of colonies represents the number of original bacteria only when the bacteria are single. If they are clustered like Staphylococcus, or in long chains like Bacillus mycoides or some Streptococcus strains, one colony may represent a large number of cells. As long as not all cells from such a cluster die, the rest will still give rise to a colony, and death becomes evident only when the last of the cells in that cluster is dead. Such clusters "die" like multicellular organisms, and their survivor curves must be concave downwards. This is commonly observed with Staphylococcus (see Fig. 7).

Substantial support was given to this explanation by Wyckoff and Rivers (1930) who irradiated bacteria spread of an agar surface (see Fig. 8). In one experiment the bacteria were exposed immediately after having been spread; the survivor curve was then nearly rectilinear. In another experiment the bacteria remained several hours on the agar surface before irradiation, and had multiplied to aggregates of perhaps 4 to 16 cells. As long as not every cell in such an aggregate was killed by X-rays, a colony developed, and the survivor curve was similar to that of a multicellular organism. Many recorded bacterial survivor curves resembling those of higher organisms can be interpreted in this way (Rahn, 1930).

The Effect of the Age of the Cell. It has been demonstrated by Sherman and Albus (1923) 


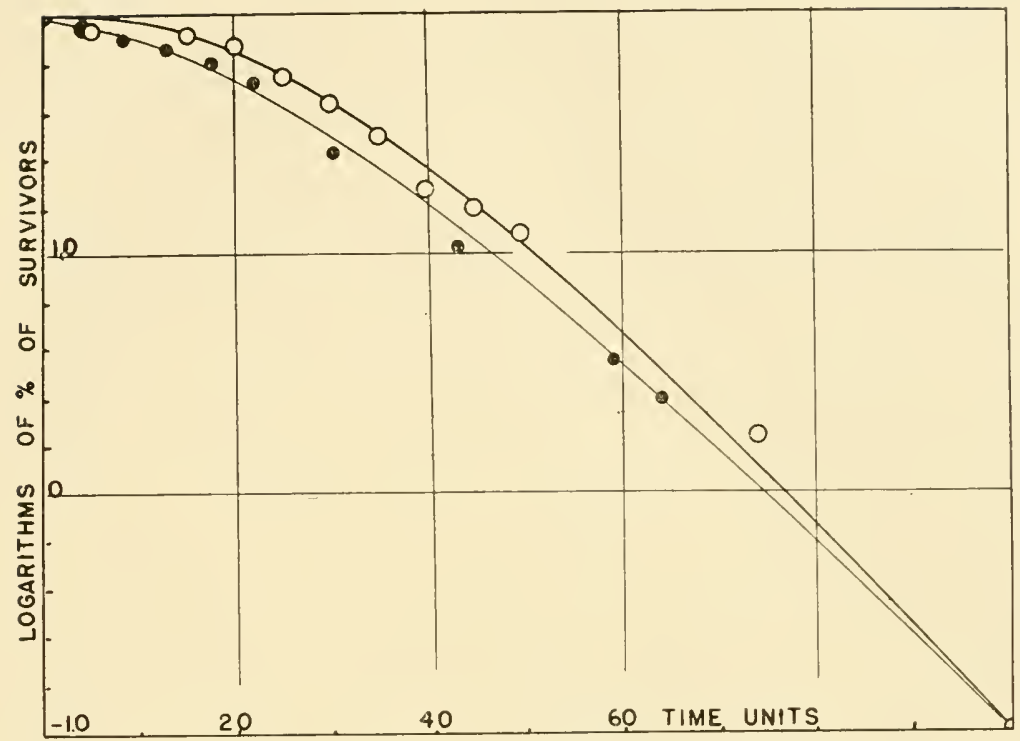

Fig. 7. Semi-logarithmic plot of survivor curves of Staphylococcus aureus killed by $0.6 \%$ phenol. (From data of Chick, 1908; the two curves have been drawn to the same scale.)

that young bacterial cells succumb more readily to harmful influences than old cells. The term "old cells" is applied to cells of cultures which have nearly or completely reached the maximal population. With the customary technique of the bacteriologist and with the customary test cultures, this stage is reached in about 24 hours. "Young' cells" are cells from cultures 2 to 8 hours old. An increase of the age beyond that required to reach the maximal population does not usually increase the resistance of the cells very much. Although many cells lose their viability after the stage of maximal population is passed, those cells which remain viable do not seem to be weakened by old age, and their resistance to disinfectants or heat is not decreased. Howerer, they require a longer time for adjustment before they can start to multiply again in a new medium. 
When old cells are transferred to a new environment they are dormant and do not all begin to grow at the sume time. Some cells start much earlier than others, and the general picture is probably similar to that of the germination of Aspergillus spores shown in Figure 12. This leads to great contrasts in sensitivity since very young and very old cells occur side by side. If such cultures are treated with antiseptics or heat, the survivor curves are very markedly concave upwards. They become more and more nearly straight as the culture gets older. This

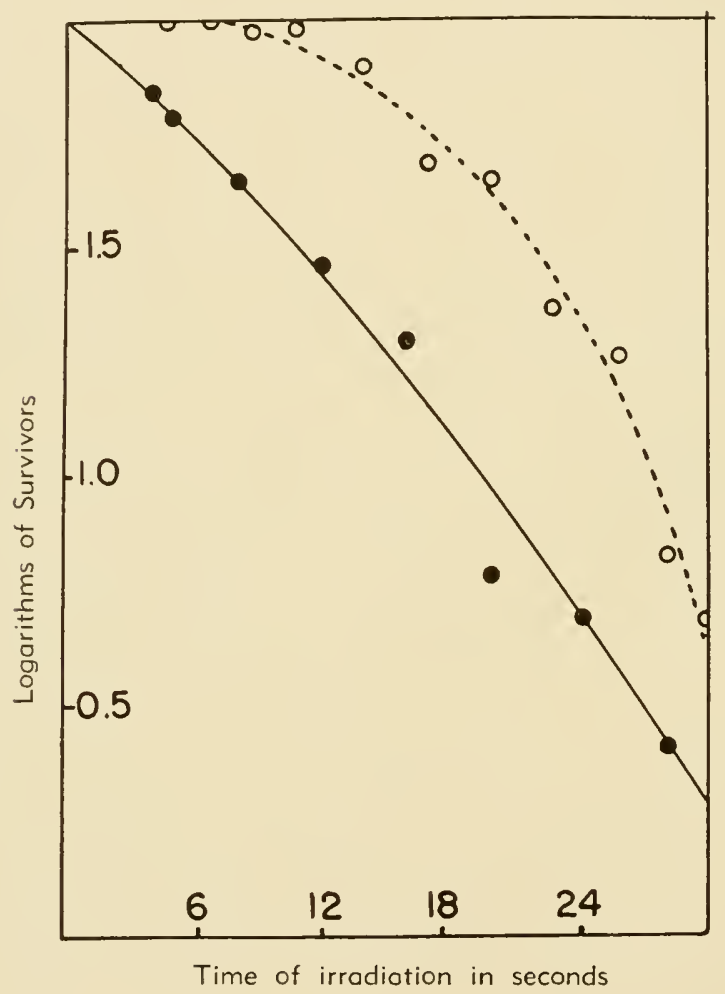

Fig. 8. Order of death of Bacterium coli killed by X-rays. The solid line represents the order of death when the bacteria were exposed to $\mathrm{X}$-rays immediately after being spread on agar; the dotted line, when they were exposed a few hours after being spread. (From data of Wyckoff and Rivers, 1930.) 
was shown by Reichenbach (1911) with a culture of Bucterium paratyphosum exposed to heat (see Fig. 9; since the temperatures used by this author were not exactly alike in the different experiments, the data have been made comparable by recalculation to a standard scale where $99.9 \%$ of the inoculum are killed in 100 time units.)

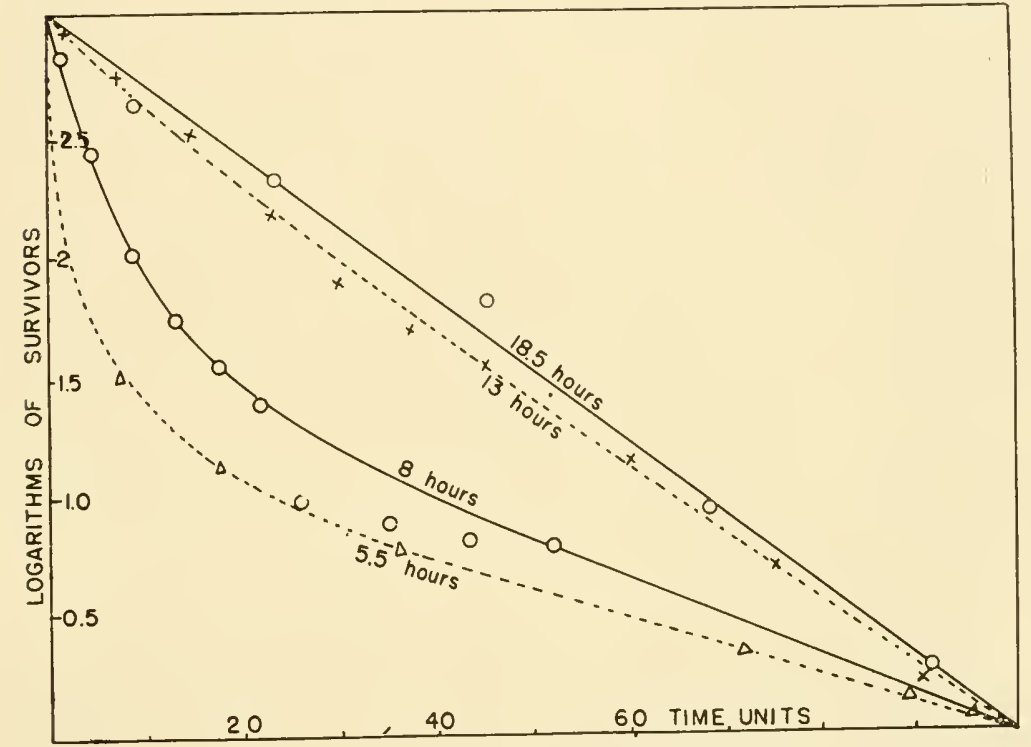

Fig. 9. Semi-logarithmic plot of survivor curves of a culture of Bacterium paratyphosum exposed to heat at different time intervals after inoculation. Abscissa: time of exposure. (From data of Reichenbach, 1911.)

The observation that young cells are more sensitive than old ones is readily accepted by biologists because it agrees with analogous findings with higher plants and animals. Even in higher organisms, however, certain exceptions must be acknowledged, for instance, the greater resistance of children against certain diseases. It is interesting that similar exceptions have been observed by Hoffmann (unpublished) with bacteria. Gentian violet inas a much stronger effect on old bacteria than on young ones. 

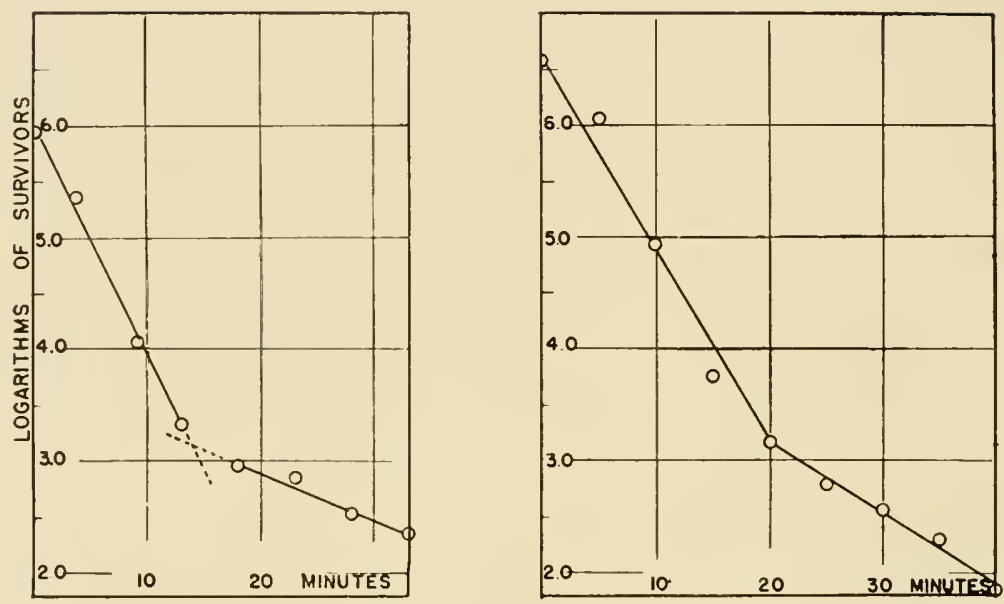

Fig. 10. Sharp breaks in survivor curves.

Left: Bacterium schottmuelleri killed by exposure to $55^{\circ}$.

Right: Monilia candida killed by exposure to $50^{\circ}$.

(From data of Beamer and Tanner, 1939a, b.)

Another phenomenon probably due to the effect of age upon the resistance of bacteria, although definite proof is still lacking, is the abrupt break in survivor curves which has been frequently observed in heat disinfection, but which occurs also in chemical disinfection. Figure 10 shows a typical example.

The first quantitative records of this phenomenon were made by Gage and Stoughton (1906) who found that when old cultures of Bacterium coli were exposed to heat, a few cells remained alive for a long time after the large majority had died. In one experiment, $99.99 \%$ of the cells were killed in 5 minutes at $60^{\circ}$, but a few survived even when heated to $85^{\circ}$ for 5 minutes.

The great practical difficulties arising from this phenomenon in pasteurization and sterilization will be dis- 
cussed elsewhere, but the principle should be discussed here. In those instances in which this outstanding resistance of a few individuals was oberved, the number of resistant eells was always very small, usually mueh smaller than $0.1 \%$. Even if these cells were morphologically different, it would be difficult to find them under the microseope among the mass of normal cells. But it is probable that they are not different, for their progeny differs in no way from the parent culture (not even in resistance, as will be seen below).

It may be that the few survivors are very old cells which failed to come out of their resting stage when transferred to a new medium. In general, one loopful of a grown culture transfers between one million and ten million cells. If some of these remain in the resting stage for 24 hours, a new transfer from this culture would earry over a considerable number of cells much older than the average, and they would not multiply readily, but would more probably remain in the resting stage. It would require at least three suceessive transfers at short intervals to eliminate such cells. This explanation does not require that the resistance inerease with age. It merely assumes that all other cells are much younger and therefore more sensitive.

The Order of Death in the Case of L o w Deathrates. When death is very slow, the survivor curves seem to be generally eoncave downwards. Howerer, most of Knaysi's experiments (1930, II) with very weak disinfectants show a decreasing death rate and survivor curves which are concave upwards. This indieates some inhomogeneity in the material, which was probably due to the use of agar-grown bacteria instead of broth-grown cells. Woerz (1931, unpublished) observed that Torulu cremoris, which does not form clusters, died in logarithmic order when held at a temperature well above the maximal temperature of growth; but at tem- 
peratures near this maximum, the survivor curve became definitely concave downwards (Fig. 11). If we realize that with many species the synthesis mechanism can reproduce all the parts of a cell in 15 to 30 minutes, it is not surprising that the effect of repair becomes perceptible when the process of dying is extended over several hours.

The following simplified analysis might make clear the writer's conception of the interaction between death and repair. Let us assume that death is brought about by the inactivation of the mechanism of cell division and that the earliest phase of this process can be reversed by the synthesis mechanism. Let the rate of injury be $50 \%$ (that is, affect $50 \%$ of the cells) per hour, and the rate of repair during the first hour be $40 \%$. Then, only $10 \%$ of the cells camnot be repaired, and the death rate is $10 \%$. But, the harmful environment affects not only reproduction, but also the synthesis mechanism which, we as-

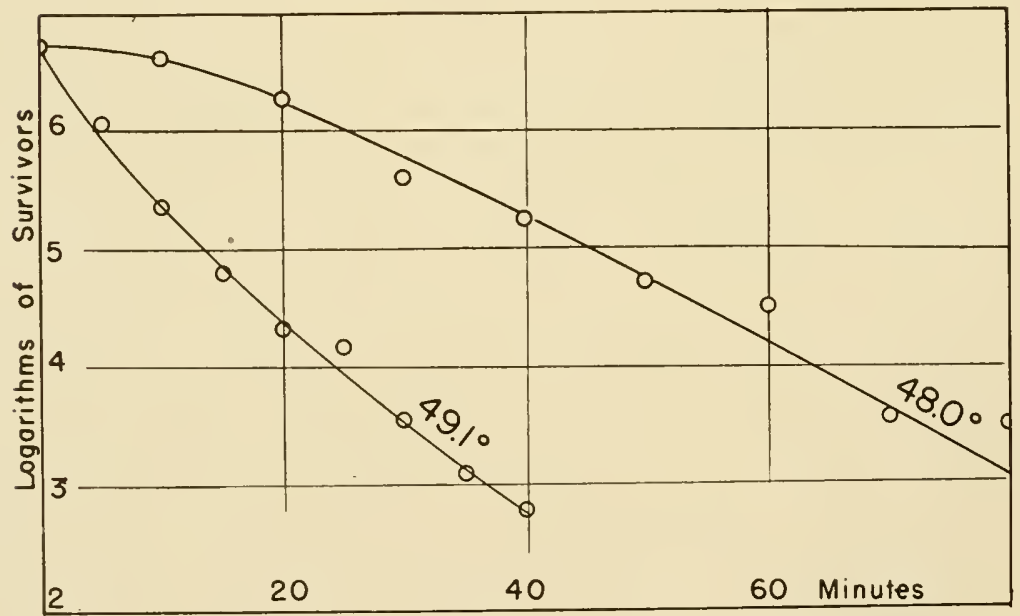

Fig. 11. Death by heat of Torula cremoris. This graph shows that different types of curves may be obtained when death is slow (at $48^{\circ}$ ) and when it is rapid (at $49.1^{\circ}$ ). From data of Woerz, 1931, unpublished.) 
TABLE 8

Dependance of the death rate on the rates of injury and of repair. Each figure represents the per cent of the cells which survived at the end of the previous time unit.

At given rates of injury and of repair one has:

\begin{tabular}{c|c|c|c|c|c}
\hline after & 1 hour & 2 hours & 3 hours & 4 hours & 5 hours \\
\hline Cells injured every hour.... & $50 \%$ & $50 \%$ & $50 \%$ & $50 \%$ & $50 \%$ \\
Cells repaired every hour... & $40 \%$ & $20 \%$ & $10 \%$ & $5 \%$ & $2.5 \%$ \\
Cells dying every hour.... & $10 \%$ & $30 \%$ & $40 \%$ & $45 \%$ & $47.5 \%$ \\
\hline
\end{tabular}

When the process of injury is accelerated 10 times while the decrease of the repair rate remains the same, the corresponding figures are:

\begin{tabular}{c|r|r|r|r|l}
\hline after & 6 min. & $12 \mathrm{~min}$. & $18 \mathrm{~min}$. & $24 \mathrm{~min}$. & $30 \mathrm{~min}$. \\
\hline Cells injured every 6 min... & $50 \%$ & $50 \%$ & $50 \%$ & $50 \%$ & $50 \%$ \\
Cells repaired every 6 min. & $4 \%$ & $2 \%$ & $1 \%$ & $0.5 \%$ & $0.25 \%$ \\
Cells dying every 6 min... & $46 \%$ & $48 \%$ & $49 \%$ & $49.5 \%$ & $49.75 \%$ \\
\hline
\end{tabular}

sume, loses half of its efficieney per hour. Thus, repair during the second hour is only $20 \%$ while injury contimues its constant rate of $50 \%$, which results in the death of $50-20=30 \%$ during the second hour. In the third hour, with repair decreased to $10 \%, 40 \%$ die. The further stages are shown in Table 8.

The second half of this table shows what happens if death is much more rapid. It is assumed that injury has become 10 times as fast, so that $50 \%$ of all cells are now injured in 6 minutes instead of in 60 minutes. The amount of repair possible in this short time is almost negligible, even if we assume that injury of the synthesis mechanism is not increased, and the percentage of cells lying per time unit is now nearly constant from the begimning.

The Order of Death of Other Unic ellular Organisms. If death, i.e., loss of re- 
production, is due to the lethal inactivation of some gene, this must apply not only to bacteria, but to all other unicellular beings as well, at least as long as they are mononucleate. That the order of death of yeast is logarithmic has been shown by Woerz (Fig. 11), by Rahn and Barnes (1933) and especially by Beamer and Tanner (1939b). Some of the data obtained by the last mentioned authors are given in Fig. 2 and Table 7 . Since certain species of yeast have a tendency to form cell aggregates in consequence of the fact that the daughter cells, and even the third generations, frequently remain attached to the mother cells, the survivor eurves may eventually become coneave downwards (Eijkman, 1912). Beamer and Tanner avoided clumps by shaking their stock cultures for 30 minutes and filtering them through cotton before exposure.

The survivor curves of mold spores, whether death is caused by heat or by disinfectants, are concave downwards (Henderson Smith, 1921 and 1923). Although multinuclear, the spores could not develop, or would at least become abnormal, if one of the nuclei were inactivated. On that basis one would expect a logarithmic order of death. But it is probable that spores are fairly resistant in their natural dry state, and the penetration of water is known to be a slow process requiring considerable time. Germination is often irregular. Fig. 12 shows the rate of germination of the spores of Aspergillus niger on an agar surface. The percentage of germination was ascertained every 10 minutes, and the mold spores were found to be very inhomogeneous. Since germination as well as disinfection depends above all upon the penetration of water, such material cammot be expected to show a constant death rate. However, X-rays should cause a logarithmic order since they penetrate instantaneously. 


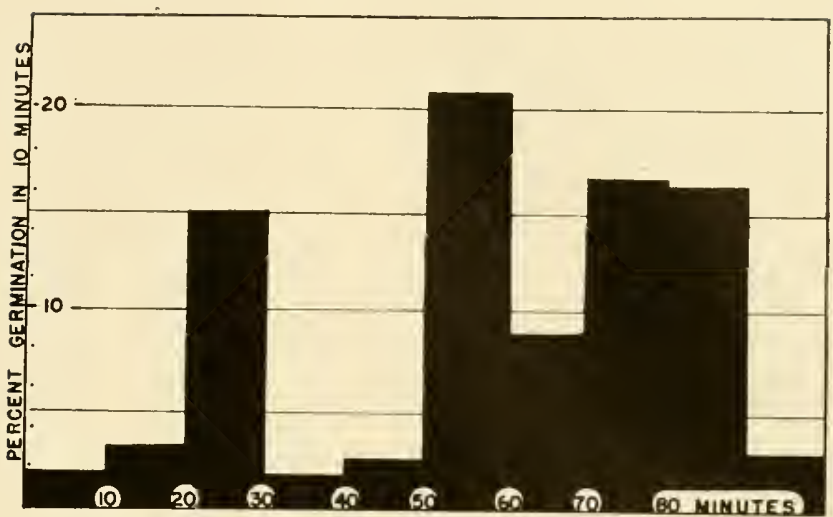

Fig. 12. Irregularity in the number of spores of Aspergillus which germinate per time unit (on an agar surface). Abscissa: time from the moistening of the spores; ordinate: per cent of germinating spores.

The order of death of algae has been studied oceasionally. Harvey (1909) found a logarithmic order when Chlamydomonas was treated with hydrochloric acid (Fig. 13). The criterion was the loss of motility.

With protozoa, the same criterion resulted in a survivor curve which was pronouncedly concave downwards. Peters (1920) studied death in the flagellate Colpidium in dilute solutions of $\mathrm{Hg} \mathrm{Cl}_{2}$; the survivor curve he obtained is shown in Figure 14. It is possible, of course, that loss of motility is one of the latest symptoms to become noticeable, and that the protozon were doomed to die before this criterion could be observed.

Unexplained Deviations from the Logarithmic $O r d e r$. The evidence on hand is overwhelmingly in favor of logarithmic order of death in bacteria, and isolated reports of exceptions could be disregarded. However, there are some consistant exceptions which cannot be disregarded although they are unexplained. The following two very extensive sets of experiments on disinfection by chlorine, carried ont inde- 


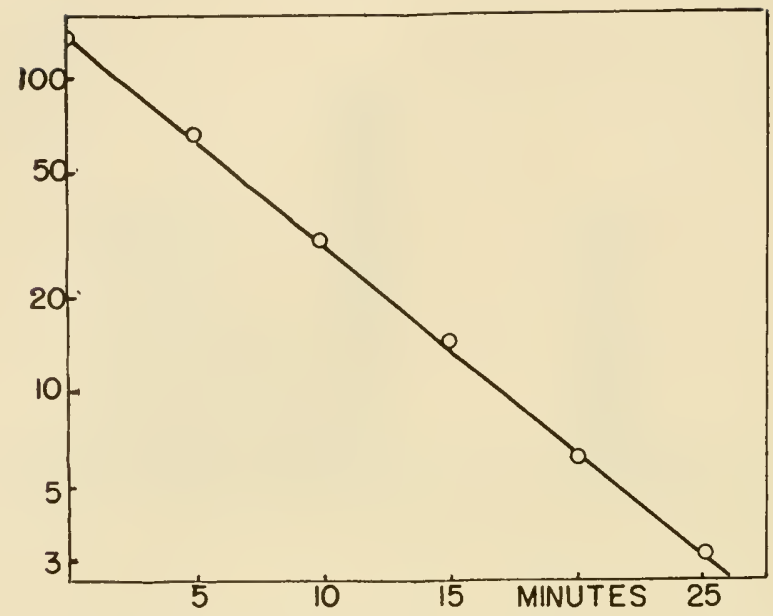

Fig. 13. Semi-logarithmic plot of the survivor curve obtained with the alga Chlamydomonas killed by $0.009 \% \mathrm{HCl}$. Abscissa: time of exposure; ordinate: number of survivors on logarithmic scale. (From data of Harvey, 1909.)

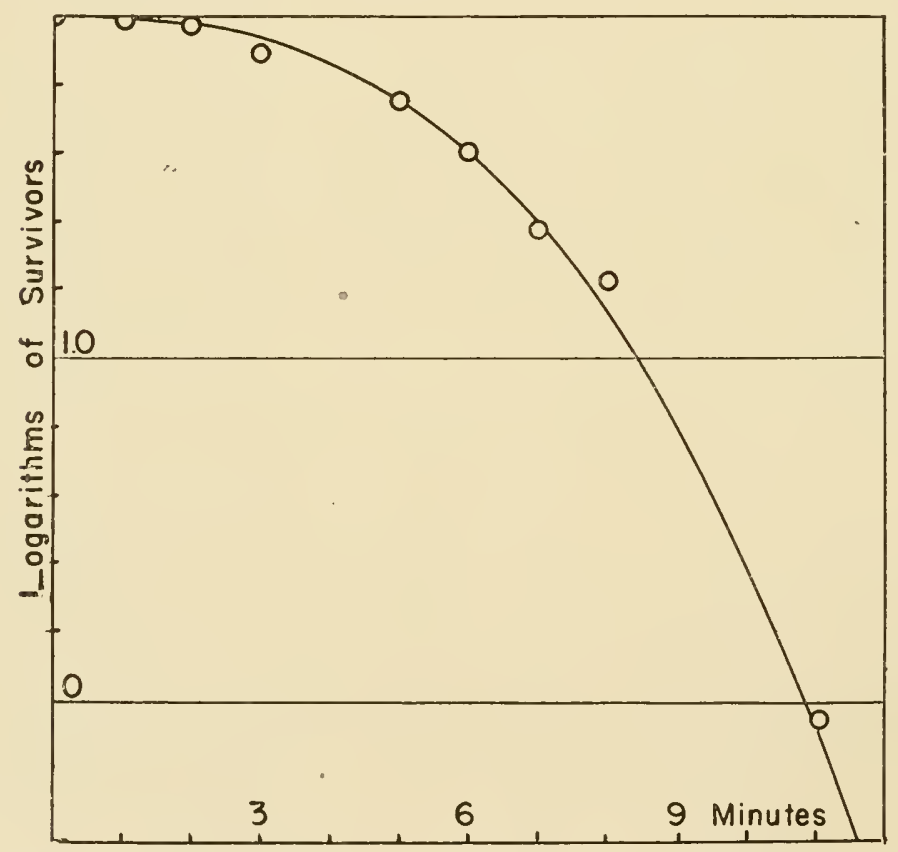

Fig. 14. Semi-logarithmic plot of the survivor curve obtained with the protozoon Colpidium killed by mereury bichloride. (From data of Peters, 1920.) 
pendently, resulted in survivor curves which were concare downwards. Charlton and Levine (1937) suspended the dried spores of a Bacillus (either laterosporus or ruminatus)-which were found by microscopic inspection to be mostly single-in water with rarying amounts of chlorine, and connted the survivors by plating. Mallmann and Ardrey (1940) used a suspension of Bacterium coli in water which had been chlorinated 30 minutes previously; their results are represented in Fig. 15.

It is remarkable that chlorine differs so much in this respect from most other disinfectants. No comparison with iodine could be made since the order of death by iodine does not seem to liare been inrestigated. It is conceivable that chlorine, being such a very active chemical reagent, kills bacteria by destroying the membrane, or the protoplasm, or the enzymes before attacking the mechanism of reproduction. This would result in the observed order of death.

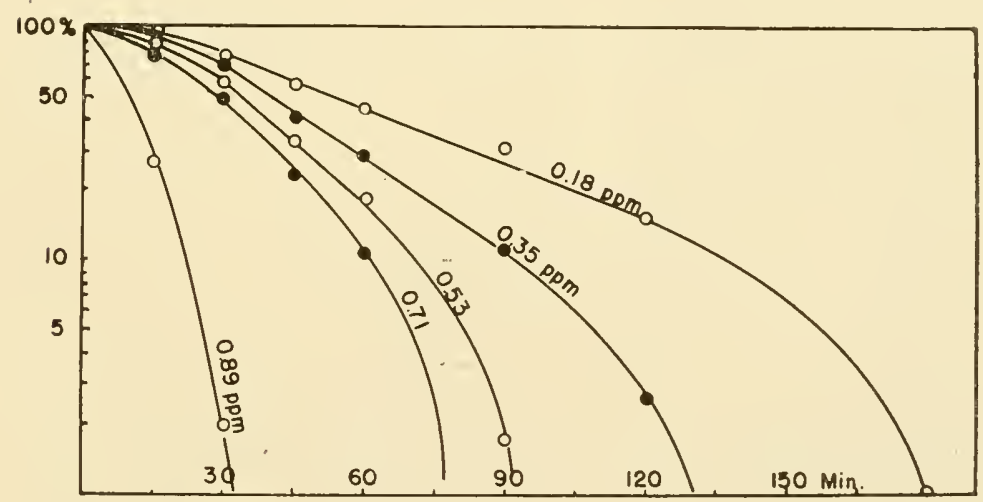

Fig. 15. Semi-logarithmic plot of survivor curves of Bacterium coli treated with chlorine. Abscissa: time of exposure; ordinate: per cent of survivors, on logarithmic scale. (From data of Mallmann and Andrey, 1940.) 


\section{BIOLOGICAL CONSEQUENCES OF THE LOGARITHMIC ORDER OF DEATH}

Importance of the $N u m b e r$ of $I n$ dividuals. Let us consider again the case diseussed on page 16 of a million bacteria per cubic centimeter dying at the rate of $90 \%$ per minute. The survivors at 9 consecutive minutes will be:

$$
\begin{array}{lllllllll}
100,000 & 10,000 & 1,000 & 100 & 10 & 1 & 0.1 & 0.01 & 0.001
\end{array}
$$

(This last number means that there is one bacterium left alive in 1,000 c.c. If the bacterial suspension were distributed in ampules of 10 c.e. each, one ampule out of a hundred would still contain one living bacterium.) If instead of a million, we had only 1,000 bacteria per c.c. at the outset, the same degree of sterilization would have been reached in 6 minutes instead of in 9 . The exposure time for sterilization thus depends upon the amount of contamination. It is a logarithmic function of the number of cells present. If we have two suspensions of the same bacterium, one with $a$ cells and the other with mu, and if the death times required to reach the same degree of sterilization in the two cases are, respectively, $t_{1}$ and $t_{2}$, we have the equations

$$
\begin{aligned}
K t_{1} & =\log \frac{a}{a-x} \\
K t_{2} & =\log \frac{m a}{m a-y}
\end{aligned}
$$

$x$ and $y$ being the number of bacteria dead at the times, $t_{1}$ and $t_{2}$, respectively. The same degree of sterilization is reached when $a-x=m-y$. Subtracting the second equation from the first we obtain:

$$
\mathrm{K}\left(\mathrm{t}_{2}-\mathrm{t}_{1}\right)=\log \mathrm{m}
$$

This means that if one inoculum is $m$ times as large as the other, the increase in death time $\left(t_{2}-t_{1}\right)$ is proportional to $\log \mathrm{m}$, and inversely proportional to the rate of death. 
This equation could be used, in the following form, to determine the death rate:

$$
K=\frac{\log m}{t_{2}-t_{1}}
$$

That the amount of contamination influences very definitely the time required for sterilization, is an every-day experience in the dairy industry, in the canning industry and in surgery. Quantitative data, given by Fisty and Myers (1922) on spores of Clostridium botulinum, are reproduced in Table 9 . Sometimes $K$ is not constant,

TABLE 9

Time required to sterilize by heat cultures of different concentrations of spores of Clostridium botulinum. (From Esty and Meyer, 1922.)

\begin{tabular}{|c|c|c|c|c|}
\hline & $\begin{array}{l}\text { Number of } \\
\text { spores } \\
\text { per cc. }\end{array}$ & $\begin{array}{c}\text { Some spores } \\
\text { still } \\
\text { alive after }\end{array}$ & $\begin{array}{l}\text { All spores } \\
\text { dead } \\
\text { after }\end{array}$ & $K=\frac{\log m}{t_{2}-t_{1}}$ \\
\hline $105^{\circ}$ & $\begin{array}{r}900,000,000 \\
9,000,000 \\
90,000 \\
900 \\
9\end{array}$ & $\begin{array}{l}44 \text { minutes } \\
34 \text { minutes } \\
18 \text { minutes } \\
12 \text { minutes } \\
\ldots \ldots \ldots \ldots\end{array}$ & $\begin{array}{l}48 \text { minutes } \\
36 \text { minutes } \\
20 \text { minutes } \\
14 \text { minutes } \\
2 \text { minutes }\end{array}$ & $\begin{array}{l}0.17 \\
0.14 \\
0.17 \\
0.17\end{array}$ \\
\hline $100^{\circ}$ & $\begin{array}{r}72,000,000,000 \\
1,640,000,000 \\
32,000,000 \\
650,000 \\
16,400 \\
328\end{array}$ & $\begin{array}{r}230 \text { minutes } \\
120 \text { minutes } \\
105 \text { minutes } \\
80 \text { minutes } \\
45 \text { minutes } \\
35 \text { minutes }\end{array}$ & $\begin{array}{l}240 \text { minutes } \\
125 \text { minutes } \\
110 \text { minutes } \\
85 \text { minutes } \\
50 \text { minutes } \\
40 \text { minutes }\end{array}$ & $\begin{array}{l}0.013 \\
0.026 \\
0.032 \\
0.035 \\
0.041\end{array}$ \\
\hline
\end{tabular}

but decreases as the cell concentration increases. This is attributable to the protective effect of large numbers of dead cells (see p. 59). 'The second half of Table 9 shows this effect when the number of spores is nearly 100 times as large as that employed in the upper half.

The outstanding fact that an increase in infection increases the death time is contrary to any explanation of the order of death by various degrees of resistance. Cells of very high resistance are rare and a large quantity of bacteria may contain a few extremely resistant cells which are not usually encountered in small quantities. 
But, as Hastings, Fred and Carroll (1925) remark, “one million spores should include all grades of heat resistance." Then in the 900 million suspension of Table 9 there should be no spore which is more resistant than those in the 9 million suspension. Accordingly, though the suspension with $900,000,000$ spores survives 12 minutes longer than the one with $9,000,000$, this difference camnot be explained by a graded resistance. The assumption that death is caused by the inactivation of a single molecule per cell fits the facts perfectly.

This influence of very large numbers of individuals shonld make itself felt also in higher organisms. In Table 4, for instance, for $n=4$, it was computed that after 5 minutes, 1 out of 10 individuals is alive, after 8 minutes, 1 out of 100 , after 12 minutes 1 ont of 1,000 and after 15 minutes 1 out of 10,000 . As $n$ increases, the $a b$ solute time differences remain the same, although their effect is relatively smaller. Actual experiments with very large numbers of higher organisms are not known to the author. Possibly some investigations on the viability of seeds have been made which would give information on this point.

Selection of Resistant Strains. Bacteria can become accustomed, to a certain degree, to aldverse conditions, and strains of remarkable resistance do occasionally oceur. If the last survivor is the most resistant, it should be easy to prodnce such a resistint strain by simply propagating the last survivors from a large number of exposed bacteria. However, if the death of the cell results from a lethal mutation, the last survivor is not different from the bacterium which is the first to die ( see page 40).

Several attempts to obtain resistant strains from the last survivors have been published, and in most cases, failure was reported. One of the most extensive and persistent attempts is that by Gage and Stoughton (1906) who tried to obtain a heat-resistant strain of Bacterium 
coli by cultivating the last survivors of a culture heated to $60^{\circ} \mathrm{C}$. Resistance was measured by the percentage of survivors after heating 5 minutes to temperatures from $45^{\circ}$ to $100^{\circ}$. The survivors of the $60^{\circ}$ heating were again cultivated, and tested, and this was carried through for nine "generations." (See the results on Table 10). Summarizing, the anthors write: "Experiment 195 in which we attempted to produce by the survival of the fittest a

TABLE 10

Comparative resistance of successive cultures of last survivors of $B$. coli. Each figure represents the per cent of survivors after 5 minutes heating at the temperature indicated. (From Gage and Stoughton, 1906.) $B$. coli can multiply at $45^{\circ}$.

\begin{tabular}{|c|c|c|c|c|c|c|c|c|c|}
\hline \multirow{2}{*}{$\begin{array}{c}\text { Heated, } \\
{ }^{\circ} \mathrm{C} .\end{array}$} & \multicolumn{9}{|c|}{ Generations } \\
\hline & 1 st & 2nd & $3 r d$ & 4 th & 5 th & 6 th & 7 th & 8 th & 9 th \\
\hline 45 & $136.0 \%$ & $86.0 \%$ & $100.0 \%$ & $63.0 \%$ & $72.0 \%$ & $63.0 \%$ & $258.0 \%$ & $64.0 \%$ & 243.0 \\
\hline 50 & 70.0 & 3.6 & 44.0 & 46.0 & 20.0 & 23.0 & 4.5 & 9.7 & 49.0 \\
\hline 55 & 4.4 & 0.006 & 0.050 & 2.3 & 0.004 & 0.020 & 0.020 & 0.012 & 0.200 \\
\hline 60 & 0.001 & 0.008 & 0.010 & 0.001 & 0.009 & 0 & 0.160 & 0.002 & 0 \\
\hline 65 & 0.250 & 0.400 & 0.001 & 0.001 & + & 0 & 0.020 & 0 & 0 \\
\hline 70 & 0.030 & 0.001 & 0.002 & 0 & 0 & 0 & 0.010 & 0 & 0.022 \\
\hline 75 & 0.050 & 0.014 & 0.003 & + & 0 & 0 & 0 & 0 & 0 \\
\hline 80 & 0.015 & + & 0.003 & + & 0 & 0 & 0 & 0 & 0.018 \\
\hline 85 & 0.003 & 0 & + & 0 & 0 & 0 & 0 & 0 & 0 \\
\hline 90 & 0.003 & 0 & 0 & 0 & 0 & 0 & 0 & 0 & 0 \\
\hline 95 & 0 & 0 & 0 & 0 & 0 & 0 & 0 & 0 & 0 \\
\hline 100 & 0 & 0 & 0 & 0 & 0 & 0 & 0 & 0 & 0 \\
\hline
\end{tabular}

race of especially resistant organisms, demonstrated a diametrically opposite result." This decrease in resistance by repeated transfer of last survirors is shown in the Table.

Gates (1929) found that "cocei from colonies of the last surviving organisms have proved to be inherently no more than normally resistant to ultraviolet light.",

The positive results obtained by Magoon (1926) are probably due to an erroneous interpretation of the data (Rahn, 1932, page 299).

Strains of unusual resistance can be obtained by exposure of large numbers of bacteria and by continuous 
transfer of large numbers to media containing different amounts of disinfectants. The customary means of transfer is a loop which holds about 0.01 cc. of liquid. One loopful of a grown culture of bacteria contains between 1 and 10 million bacteria. Only a few of these can adapt themselves to the disinfectant, and only these cells multiply. This does not mean that they would be the last survivors if stronger concentrations were applied. In this way, Borman (1932) obtained strains of Bacterium culi resistant to salts of $\mathrm{Fe}, \mathrm{Cu}$, and $\mathrm{Hg}$, and Meader and Feirer (1926) could greatly increase the resistance of several species of bacteria to silver nitrate, mercurochrome, formaldehyde, acriflavin, hexyl resorcinol and phenol.

The outstanding cases of acquired drug-fastness are met with in chemotherapy where a large number of pathogenic micro-organisms are exposed to the drugs.

$$
\text { Protection of Living by Dead Cells. }
$$
Lange (1922) was probably the first investigator to demonstrate experimentally that the presence of dead bacteria retards the death of others. He found that the death

\section{TABLE 11}

Protection of living cells by dead cells in broth. (From Lange, 1922.)

\begin{tabular}{l|c|c|c|c|c|}
\hline Standard suspension & Water & Broth & \multicolumn{2}{c}{$\begin{array}{c}\text { Culture living }(+) \text { or dead }(0) \\
\text { after }\end{array}$} \\
\hline Living cells Dead cells & $\ldots . .$. & $\ldots . .$. & $5^{\prime}\left|10^{\prime}\right| 20^{\prime}\left|30^{\prime}\right| 45^{\prime} 60^{\prime}\left|120^{\prime}\right| 180^{\prime} \mid 240^{\prime}$ \\
\hline
\end{tabular}

Bact. coli at $60^{\circ} \mathrm{C}$.

\begin{tabular}{|c|c|c|c|c|c|c|c|c|c|c|c|c|}
\hline $\begin{array}{l}0.02 \text { drops } \\
0.02 \text { drops. }\end{array}$ & 1 c.c. & $\begin{array}{c}1 \mathrm{c} \mathrm{c} . \\
\ldots \ldots\end{array}$ & $\begin{array}{l}5 \text { c.c. } \\
5 \text { c.c. }\end{array}$ & $\begin{array}{l}+ \\
+\end{array}$ & $\begin{array}{l}+ \\
+\end{array}$ & + & $\begin{array}{l}+ \\
+\end{array}$ & $\begin{array}{l}0 \\
+\end{array}$ & $\begin{array}{l}0 \\
+\end{array}$ & $\begin{array}{l}0 \\
0\end{array}$ & $\begin{array}{l}0 \\
0\end{array}$ & $\begin{array}{l}0 \\
0\end{array}$ \\
\hline
\end{tabular}

Micr. pyogenes at $56^{\circ} \mathrm{C}$.

\begin{tabular}{|c|c|c|c|c|c|c|c|c|c|c|c|c|}
\hline $\begin{array}{l}0.02 \text { drops. } \\
0.02 \text { drops. }\end{array}$ & 1 c.c. & $\begin{array}{l}1 \text { c.c. } \\
\ldots \ldots\end{array}$ & $\begin{array}{l}5 \text { с.с. } \\
5 \text { с.с. }\end{array}$ & $\frac{1}{+}$ & $\begin{array}{l}+ \\
+\end{array}$ & $\begin{array}{l}+ \\
+\end{array}$ & $\begin{array}{l}0 \\
+\end{array}$ & $\begin{array}{l}0 \\
+\end{array}$ & $\begin{array}{l}0 \\
+\end{array}$ & $\begin{array}{l}0 \\
0\end{array}$ & $\begin{array}{l}0 \\
0\end{array}$ & $\begin{array}{l}0 \\
0\end{array}$ \\
\hline
\end{tabular}


time of Bacterium coli or Staphylococcus aureus was doubled or even tripled by the addition of dead cells of the same species, provided that the cells were young when killed. Old cells gave no protection. (cf. Table 11). Watkins and Winslow (1932) observed the same effect in disinfection by alkali as well as by heat (Table 12). Such decrease in the death rate by accumulation of dead cells would tend to make the survivor curve slightly concave upwards, and this is the most commonly observed shape.

TABLE 12

Decrease of the death rate constant corresponding to an increase in cell concentration. (Data of Watkins and Winslow, 1932.)

\begin{tabular}{|c|c|c|c|c|c|}
\hline \multirow{2}{*}{ Killing agent } & \multirow{2}{*}{$\begin{array}{l}\text { Temper- } \\
\text { ature }\end{array}$} & \multicolumn{4}{|c|}{ Initial cell concentration in millions per cc. } \\
\hline & & over 100 & $50-99$ & $1-49$ & less than 1 \\
\hline $\begin{array}{l}\mathrm{n} / 200 \mathrm{NaOH} . . \\
\mathrm{n} / 150 \mathrm{NaOH} . . \\
\mathrm{n} / 100 \mathrm{NaOH} . . \\
\mathrm{n} / 125 \mathrm{NaOH} . . \\
\mathrm{n} / 100 \mathrm{NaOH} . . \\
\text { Borate Buffer.. } \\
\text { Heat........... } \\
\text { Heat.......... }\end{array}$ & $\begin{array}{l}30^{\circ} \\
30^{\circ} \\
30^{\circ} \\
22^{\circ} \\
22^{\circ} \\
30^{\circ} \\
50^{\circ} \\
55^{\circ}\end{array}$ & $\begin{array}{l}0.015 \\
0.055 \\
0.128 \\
0.051 \\
0.095 \\
0.280 \\
0.003 \\
0.088\end{array}$ & $\begin{array}{l}0.018 \\
0.112 \\
0.217 \\
0.062 \\
0.122 \\
0.323 \\
0.082\end{array}$ & $\begin{array}{l}0.045 \\
0.150 \\
0.465 \\
0.120 \\
0.222 \\
0.402 \\
0.006 \\
0.118\end{array}$ & $\begin{array}{c}0.061 \\
\ldots \ldots \\
\ldots \ldots\end{array}$ \\
\hline
\end{tabular}

No satisfactory explanation has been given which eovers all cases. It is obviously impossible to assume an equilibrium between dead and living cells correponding to the equilibria of chemical reactions. Watkins and Winslow state: "We can only suggest the possibility that a zone of protective substances in the menstruum surrounding a given cell may react upon the chemical or physical condition of the cell wall itself in such a way as to make it more resistant to the influence of heat."

Recently this problem has come to the foreground again in the study of the efficiency of the sulfonamide compounds. It is usually stated that amino benzoic acid (which neutralizes the effect of sulfa compounds) is released in small quantities from autolyzing cells. This 
explanation, which will be discussed elsewhere fits only the case of this one group of disinfectants and cannot be applied to other types of disinfectants or to death by heat. 


\section{PART II}

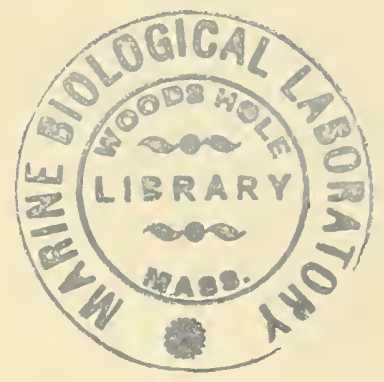

\section{MODE OF ACTION OF DISINFECTAN'TS AND ANTISEP'TICS}

In the fight against bacteria, a rather surprising variety of compounds is being used. There are oxidizing agents like hydrogen peroxide or chlorine, reducing compounds like sulfur dioxide, heavy metal salts such as those of mercury and silver, light metal salts like sodium fluoride or arsenate, acids like boric or salicylic, alkalies such as slaked lime or trisodium phosphate, alcohols like ethyl alcohol or phenol, amines, many dyes, and synthetic or natural drugs. It is not possible that all these so different compounds react with proteins in the same way. However, they all lead to the same general result, the inactivation of bacteria. This becomes understandable if one consider's that proteins are very large molecules with many different "side chains" so that they offer the possibility of a great variety of reactions which may have the same outcome on the whole molecule. Native proteins react very easily and promptly, and it is consistent with chemical experience to assume that reactions on many different side chains or atomic groups produce the same physiological result, namely, the denaturation of the protein, which thereby becomes unfit for further biological function.

The reason why so many different compounds are being used is of a practical nature; it must be sought above all in the various purposes for which they are employed. Mercury compounds cannot be used to sterilize food; salicylic acid will preserve acid fruits, but not neutral meat; chlorine is an excellent disinfectant for water, less efficient in sewage, still less so when organic mat- 
ter is concentrated; propionic acid will prevent the growth of molds, but not of bacteria; sulfa compounds work well intermally, but are poor disinfectants in vitro.

We shall use in this discussion the customary distinction between disinfectants (called also germicides or bactericides) and antiseptics, though the line of demarcation between them is not sharp. According to the general conception, disinfectants sterilize, i.e., they kill all bacteria present, whereas antiseptics merely prevent their multiplication. Disinfection is something final, irrevocable, while antisepsis is something temporary which can be interrupted or discontinued by the removal of the antiseptic.

This definition would imply, if taken literally, that antiseptics never cause death. However, most antiseptics kill at least a small percentage of cells per hour, yet death is always very slow, so that even after several days not all cells are killed. Thus a precise distinction between disinfectants and antiseptics is possible only by choosing an arbitrary time limit, and by specifying varions conditions (see below, pp. 63 and 118).

Though these specifications are arbitrary, there is clearly a fundamental difference between the temporary, reversible inhibition assumed in the definition of antiseptics and the permanent, irreversible inhibition required in that of disinfectants. In some cases, as with crystal violet, it has been proved experimentally that the chemical reaction causing reversible inhibition is different from that which causes irreversible inhibition, as will be seen below (p. 136). 


\section{DISINFECTANTS}

The difficulty of defining disinfectants has just been pointed out. To give some precision to the definition let us assume that we use as a standard method the wellknown technique of the phenol coefficient. Accordingly, a substance is considered a disinfectant if 5 ce. of the most concentrated of its commonly used solutions, mixed with $1 / 2$ ce. of a 24 -hour culture of the test organism, reduces the number of viable cells so far that, after one hour, a loopful of the suspension transferred into broth will not cause growth.

This definition excludes such compounds as $\mathrm{CuSO}_{4}$, $\mathrm{ZnSO}_{4}, \mathrm{Na}_{2} \mathrm{SO}_{3}$, all the dyes, sulfanilamide, quinine and practically all the therapeutic agents. These substances are, therefore, antiseptics, and will be considered in the second section of this review. The first section, which will treat of disinfectants proper, will include alcohol, phenol, formaldehyde, liydrogen peroxide, the silver and mercury salts, the mineral acids and the alkalies, the halogens, a few neutral salts and complex organic compounds. The soaps will also be included in the first section, though from purely practical considerations, because, while soaps really are antisepties, they are never used as such.

\section{SELECTIVITY OF DISINFECTANTS}

It has been realized from the earliest stndies of disinfection that not all bacteria react alike with the same disinfectant. Some groups, or some species, are more sensitive or more tolerant than others. An outstanding example of tolerance is that of mycobacteria towards alkali and chlorine. Another practically important example of selectivity is that of the Gram-negative and Gram-positive species which often react differently with a giren disinfectant. For this reason it has be- 
come customary to standardize disinfectants not only with the Gram-negative Bacterium typhosum, but also with the Gram-positive Staphylococcus aureus.

The degree of selectivity of various bacteria is not the same with all disinfectants. Bacterium typhosum and Staphylococcus aureus are killed by approximately equal concentrations of acetic acid while, with certain soaps, a concentration 30 times higher is required to kill the typhoid bacteria than to kill the staphylococci.

Table 13, which has been compiled from the data gathered by McCulloch (1936), gives some conception of the variations in the degree of selectivity. It shows the differences in sensitivity of the two standard test species. Small differences cannot be considered as due to selectivity since we know that, even within the same species, different strains may show remarkable variations of tolerance. Cases in which one of the test species required at least 5 times as strong a disinfectant as the other have been considered indicative of selectivity. Unfortunately, the published data on selectivity show little agreement. This is due, at least in part, to the inaccuracies in the determination of the phenol coefficient (see p. 105).

It is important for the theory of disinfection as well as for the application of disinfectants that most of the efficient, rapidly killing substances are not very selective. However, hydrogen peroxide, permanganate, alkalis and some soaps show a tendency towards selectivity. In the case of alkalis, for instance, the typhoid bacterium is killed in 10 minutes at pH 10.02 while the staphylococcus requires a $\mathrm{pH}$ of 12.2 , which represents 100 times as many $\mathrm{OH}$ ions.

Besides these differences between the standard test species, differences occur also in a few other groups of bacteria in regard to one or several disinfectants. Thus the resistance of the tubercle group towards alkali and chlorine is well-known. The waxy membrane of these bacteria may explain their exceptional behavior. Not so 


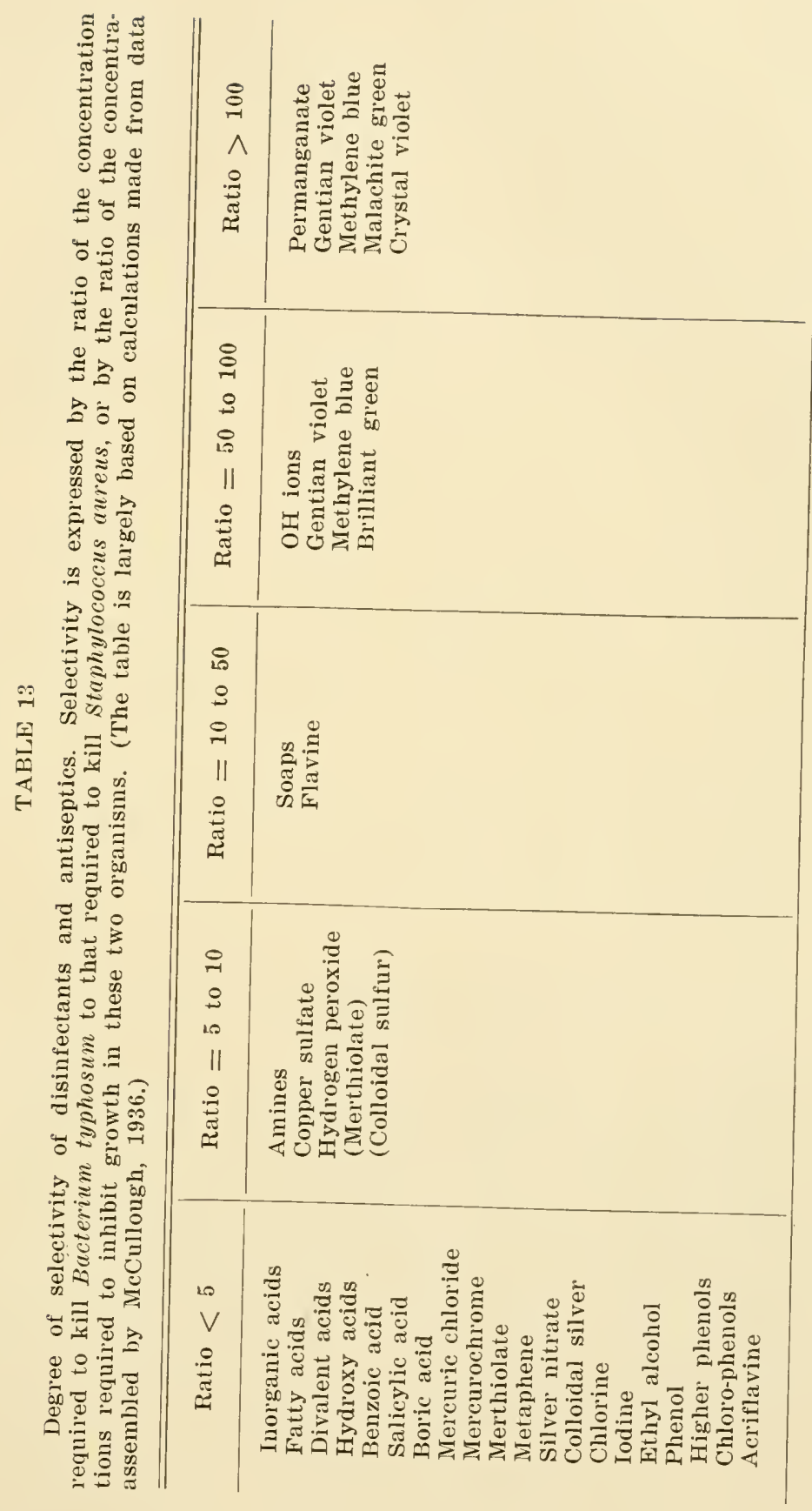


simply explained is the high degree of tolerance toward iodine exhibited by Pseudomonas pyocyanea which, on the other hand, is unusually sensitive to acids. Another remarkable instance of selectivity is that of colloidal sulfur which affects the two test species almost equally, but kills certain plant pathogens at one-tenth or one-thirtieth of the usual concentration.

With weak disinfectants, such as soap, and with many antiseptics, the difference in tolerance of the two standard test species may be hundredfold. Among the outstanding examples of extreme selectivity are some weak acids like sulfur dioxide, the dyes, the sulfa drugs, and many chemotherapeutic agents.

From these observations, certain general conclusions concerning the mechanism of death can be drawn. If a disinfectant shows no selectivity, it canses death either by reacting with a cell constituent common to all species, or by causing a reaction which is common to all proteins and which proceeds at the same rate in all species. If a substance shows pronounced selectivity, it reacts on cell constituents which are not alike in the bacterial species concerned.

\section{CONCENTRATION AND DEATH RATE}

A classical example of the effect of concentration of the disinfectant on death is shown in Table 14, which represents the action of $\mathrm{HgCl}_{2}$ on the spores of the anthrax bacillus, and is taken from the first quantitative study of chemical disinfection by Krönig and Paul in 1897.

The data of this table may be analyzed on the assumption that the course of death of bacteria is described by the equation

$$
\mathrm{Kt}=\log \frac{\text { initial number }}{\text { survivors }}
$$


where $t$ is the killing time and $K$ the deatlirate constant ${ }^{1}$. This constant was computed for each time interval and its average for each concentration is given at the bottom of Table 14.

\section{TABLE 14}

Action of various concentrations of mercuric chloride on spores of $B$. anthracis. The figures represent the number of viable spores after various times of exposure. $K$ is the deathrate constant. (From Krönig and Paul, 1897.)

\begin{tabular}{|c|c|c|c|}
\hline $\begin{array}{l}\text { Exposure time } \\
\text { in minutes }\end{array}$ & $\mathrm{M} / 16 \mathrm{HgCl}_{2}$ & $\mathrm{M} / 32 \mathrm{HgCl}_{2}$ & $\mathrm{M} / 64 \mathrm{HgCl}_{2}$ \\
\hline $\begin{array}{r}2 \\
3 \\
4 \\
5 \\
6 \\
7 \\
8 \\
9 \\
10 \\
12 \\
14 \\
15 \\
18 \\
20 \\
21 \\
24 \\
25 \\
27 \\
30 \\
35 \\
40 \\
45 \\
50\end{array}$ & $\begin{array}{c}549 \\
323 \\
236 \\
138 \\
82 \\
42 \\
19 \\
\ldots . \\
10 \\
1 \\
0 \\
\ldots . . \\
\ldots . . \\
\ldots . . \\
\ldots . . \\
\ldots . . \\
\ldots . . \\
\ldots . . \\
\ldots . . \\
\ldots . . \\
\ldots . . \\
\ldots . . \\
\ldots . \\
\\
=0.22\end{array}$ & 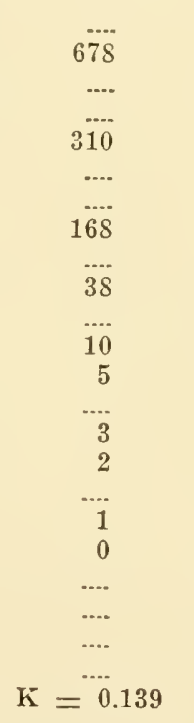 & $\begin{array}{c}\ldots . . . \\
961 \\
\ldots . . \\
\ldots . . \\
\ldots . . \\
\ldots . . \\
\ldots . . \\
\ldots . . \\
178 \\
\ldots . . \\
41 \\
\cdots . . \\
\cdots \\
9 \\
\cdots . . \\
7 \\
3 \\
2 \\
1 \\
1 \\
\mathrm{~K}=0.080\end{array}$ \\
\hline
\end{tabular}

The values of $K$ increase with the concentration, but not proportionally. In 1908, Watson, using the data by Chick (1908), showed that the relation of the death rate to the concentration is best expressed by an equation in which the concentration $c$ is raised to a power $n$. This equation is

$$
\mathrm{Ktc}^{\mathrm{n}}=\log \frac{\text { initial number }}{\text { survivors }}
$$

1. See p. 17 . 
where $K$ is the deathrate constant at the concentration $c=1$.

The value of $n$ varies greatly with different disinfectants. It may be as low as $1 / 2$ (which means that the deathrate constant is proportional to the square root of the concentration) as Paul and associates (1910) found for staphylococci exposed to hydrochloric acid. With many common disinfectants it is near 1 , as, e.g., with formaldehyde, hydrogen peroxide, metal salts, and some acids. In this case only, the death rate is directly proportional to the concentration. The highest coefficients recorded (see below, Table 15) were obtained with alcohols at concentrations of 26 to $40 \%$; but these high values may be partly due to osmotic effects or to partial dehydration of the protoplasm of the cells. Otherwise the highest values, which are in the neighborhood of 6 , were obtained with phenol and its homologues. This makes the phenol group quite different from other disinfectants.

We can calculate $n$ from the deathrate constants $K_{1}$ and $K_{2}$ at two different concentrations $c_{1}$ and $c_{2}$. The relation

$$
\frac{\mathrm{K}_{1}}{\mathrm{~K}_{2}}=\left(\frac{\mathrm{c}_{1}}{\mathrm{c}_{2}}\right)^{\mathrm{n}}
$$

gives

$$
\mathrm{n}=\frac{\log \mathrm{K}_{1}-\log \mathrm{K}_{2}}{\log \mathrm{c}_{1}-\log \mathrm{c}_{2}}
$$

Using the numerical values of Table 14, we have

$$
\frac{\log 0.22-\log 0.08}{\log 64-\log 16}=0.73
$$

The concentration exponent $n$ can also be determined from the death times, since the death times in experiments with identical inocula are inversely proportional to the deathrate constants: 


$$
\frac{\mathrm{K}_{1}}{\mathrm{~K}_{2}}=\frac{\mathrm{t}_{2}}{\mathrm{t}_{1}}=\left(\frac{\mathrm{c}_{1}}{\mathrm{c}_{2}}\right)^{\mathrm{n}}
$$

We have, therefore

$$
\mathrm{n}=\frac{\log \mathrm{t}_{2}-\log \mathrm{t}_{1}}{\log \mathrm{c}_{1}-\log \mathrm{c}_{2}}
$$

Chick (1908) found the following death times for washed cells of Bacterium paratyphosum exposed to silver nitrate:

Concentration:
$0.085 \%$
$0.017 \%$
$0.0085 \%$
$0.0017 \%$
$0.00085 \%$
$0.00017 \%$
$0.000085 \%$

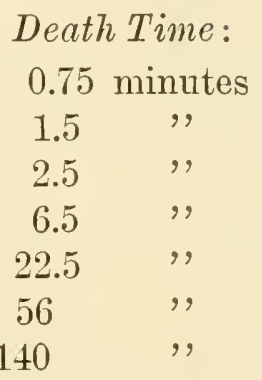

The exponent can be computed from any two sets of data. The two extremes give

$$
\mathrm{n}=\frac{\log 140-\log 0.75}{\log 1000}=0.76 \text {. }
$$

The next two values give

$$
\mathrm{n}=\frac{\log 56-\log 1.5}{\log 100}=0.79 \text {. }
$$

The significance of the concentration exponents will appear more clearly in a specific example. At a concentration of $0.7 \%$, formaldehyde and phenol have about the same disinfecting power and kill Bact. coli in about 100 mimutes. If the concentration is doubled, formaldehyde, for which $n=1$, kills in 50 mimutes, while phenol, with $n=6$, will kill in $100 / 2^{6}=100 / 64=1.6 \mathrm{~min}-$ utes. If the disinfectants are diluted with an equal volume of water, $0.35 \%$ formaldehyde will kill in $200 \mathrm{~min}$ utes while phenol requires $100 \times 2^{6}=6400$ minutes $=$ 4.5 days. 
This can be shown graphically by plotting the logarithms of the death times against the logarithms of the concentration. This type of plotting must result in a straight line, as the following reasoning indicates. In the determination of death times, the right side of the equation

$$
\mathrm{Ktc}^{\mathrm{n}}=\log \frac{\text { initial number }}{\text { survivors }}
$$

is not affected by changes in concentration because all tests of a series begin with the same initial number and end with the same number of survivors, theoretically very few, practically none. $K$, the deathrate constant for $c=1$, is also constant. We therefore obtain

$$
\mathrm{tc}^{\mathrm{n}}=\mathrm{M}
$$

where $M$ is a constint. Dividing the two members by $t$ and taking their logarithms, we have

$$
\mathrm{n} \log \mathrm{c}=\log \mathrm{M}-\log \mathrm{t}
$$

where $\log M$ is a constant. Therefore $\log t$ is a rectilinear function of $\log c$, and $n$ controls the slope of the line. Higure 16 shows the different slopes produced by different values of $n$. Figure 17 shows the curves for phenol and formaldehyde crossing each other. Curves for otler disinfectants may be found in Figure 22.

The meaning of the concentration exponent in the lethal reaction of bacteria is not clear. In chemical reactions, it frequently indicates the number of reacting molecules. In the case of disinfection, this seemed rather improbable to Watson (1908) because $u$ is not always an integer. Further, the not uncommon value $n=0.5$ should indicate that two molecules of bacterial protein react with one molecule of disinfectant, which seems highly improbable for such disinfectants as $\mathrm{HCl}$ or $\mathrm{O}_{2}$. But the assumption that $n$ corresponds to a given num- 

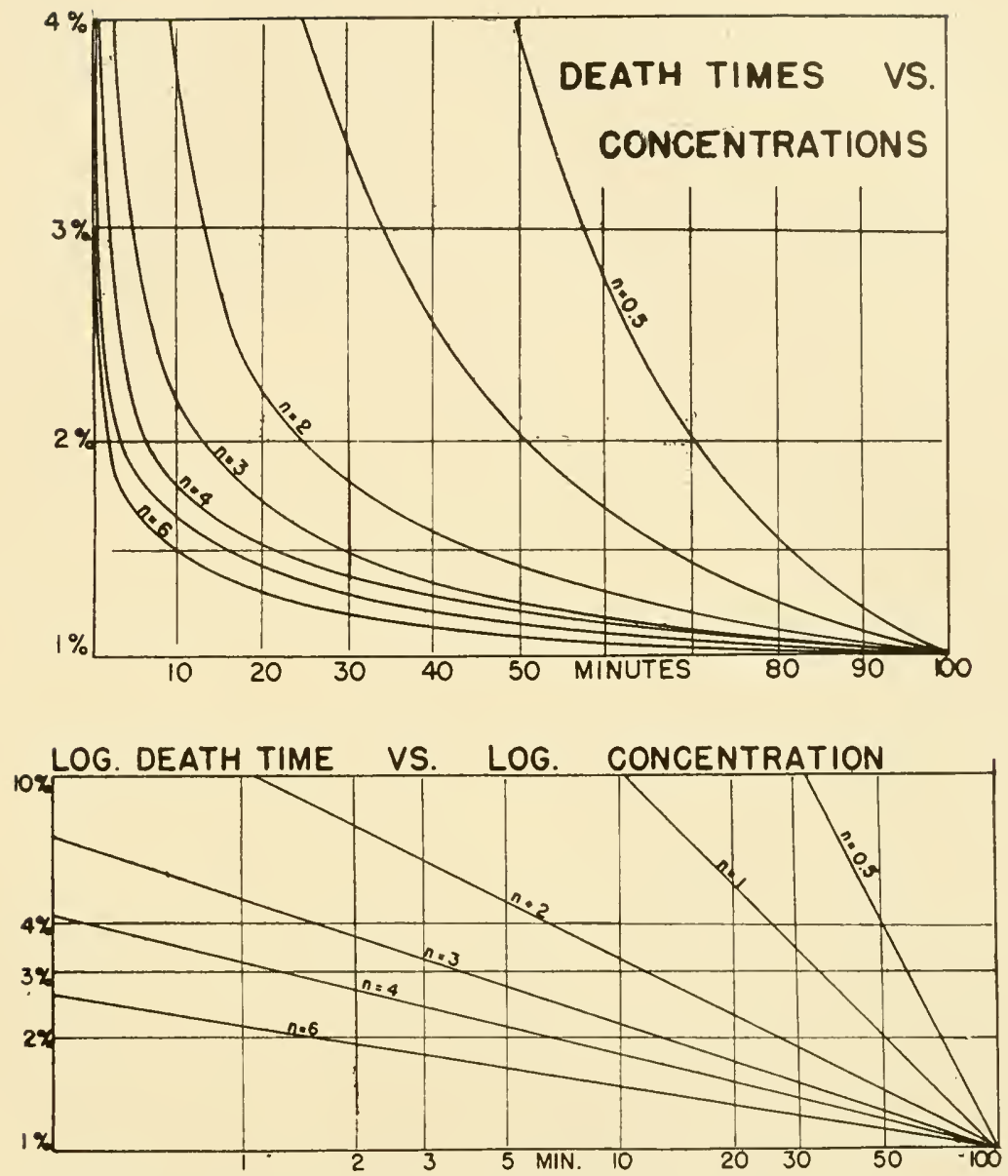

Fig. 16. Two methods of representing the relation between concentration of disinfectant and death time. The different curves illustrate how the "concentration exponents" $n$ affect the results.

ber of reacting molecules becomes definitely untenable if the observation by Tilley (1939) can be confirmed, that the exponent decreases when the temperature increases. Though Tilley's data show a good deal of fluctuation, they clearly indicate this influence of temperature (see, in particular, the figures for the concentration exponents of phenol and ethyl alcohol in Table 15). 
The alternative explanation is that the disinfectant acts as a catalyst, speeding up the very slow denaturation of some essential protein. Native proteins are never stabile. With such catalytic action, the concentration exponent need not be an integer, and it is usually greatly affected by temperature. However, the determination of $n$ in disinfection is too inaccurate to permit decision between the two theories.

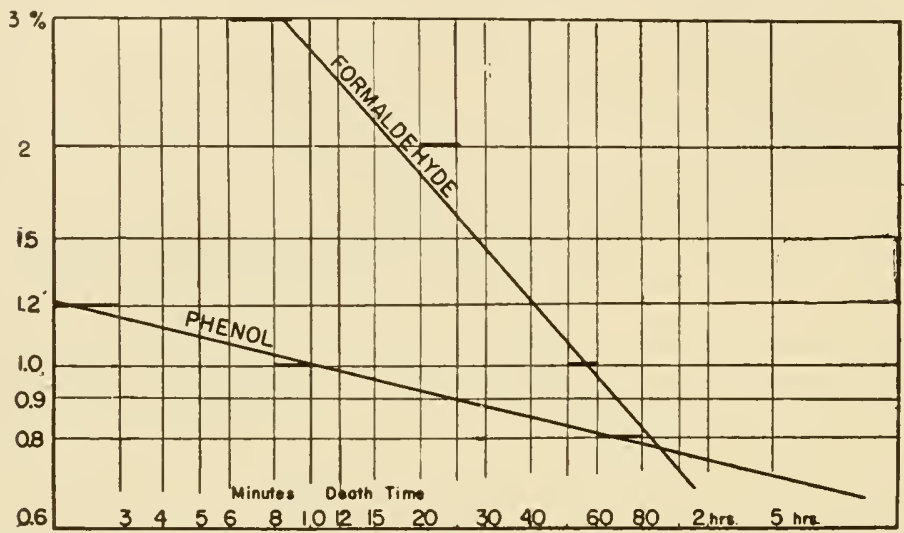

Fig. 17. Effect of various concentrations of formaldehyde and of phenol on the death time of Bacterium coli. Abscissa: death time, on logarithmic scale; ordinate: per cent concentration, on logarithmic scale. (Original data.)

Concentration exponents have been measured ocensionally since Chick (1908) and Watson (1908) first called attention to them. Only two extensive studies with large numbers of experiments have been published, those of Paul, Birstein and Reuss (1910) on different acids, and those of Tilley (1939) on the phenol group. Paul and associates used the method of death rates, Tilley the method of death times. Some data by these and other authors are shown in Table 15.

Not only do the values of "fluctuate considerably in different experiments, but Tilley found, with Bact. typhosum and phenol, that they fluctuated in the same 
experiments as follows: $9.35,5.59,11.17,8.76$; average: 8.96. A second identical experiment gave $n=7.04$ as the average of four determinations. If such fluctuations are obtained by experienced investigators, it is evident that concentration exponents are not reliable enough to serve as a basis for speculations on the mechanism of the lethal reaction.

\section{TABLE 15}

Concentration exponents of some disinfectants.

I. Acids (Paul, Birstein and Reuss, 1910)

\begin{tabular}{l|c|c|c}
\hline \hline & $\begin{array}{c}\text { Number of } \\
\text { experiments }\end{array}$ & \multicolumn{2}{|c}{$\begin{array}{c}\text { Average exponent based on } \\
\text { concentration of }\end{array}$} \\
\cline { 2 - 3 } & 4 & Acid & H ions \\
\hline Hydrochloric acid & 3 & 0.52 & 0.52 \\
Acetic acid & 3 & 0.98 & 1.95 \\
Butyric acid & 2.04 & 4.02 \\
\hline
\end{tabular}

II. Alcohols (Tilley, 1939)

\begin{tabular}{|c|c|c|c|c|c|c|c|c|}
\hline & \multicolumn{4}{|c|}{ Bact. typhosum } & \multicolumn{4}{|c|}{ Staph. aureus } \\
\hline & $10^{\circ}$ & $20^{\circ}$ & $30^{\circ}$ & $40^{\circ}$ & $10^{\circ}$ & $20^{\circ}$ & $30^{\circ}$ & $40^{\circ}$ \\
\hline Phenol & 7.9 & 7.5 & 5.9 & 5.2 & 6.5 & 6.5 & 6.4 & 5.4 \\
\hline o-Cresol & 8.3 & 7.9 & 5.5 & 5.1 & 7.8 & 7.6 & 8.1 & 6.8 \\
\hline$p$-Cresol & 8.9 & 8.4 & 6.4 & 5.3 & 8.2 & 8.7 & 9.4 & 7.0 \\
\hline o-Butyl phenol & .... & 9.2 & 7.2 & .... & $\ldots$. & 8.5 & 9.1 & .... \\
\hline$p$-Butyl phenol & . & 9.2 & 9.3 & .... & $\ldots$. & 8.9 & 8.1 & $\ldots$ \\
\hline Resorcinol & 4.6 & 5.1 & 5.2 & $\ldots$. & 4.4 & 5.0 & 6.2 & .... \\
\hline Ethyl alcohol & 12.7 & 11.4 & 8.8 & .... & 11.4 & 11.1 & 8.5 & .... \\
\hline$n$-Butyl alcohol & & 11.9 & 10.3 & .... & .... & 11.8 & 10.1 & .... \\
\hline
\end{tabular}

III. Various Compounds

Phenol

Formaldehyde

Hydrogen peroxide

Hydrogen peroxide

Silver nitrate
5.5 (Chick, 1908)

1.0 (Gegenbauer, 1922)

0.5 (Reichel, 1908)

.1.7-2.6 (Rahn, unpublished)

$0.9 \quad$ (Chick, 1908) 
There is still more inconsistency with disinfectants which combine readily with various kinds of organic matter. A typical example is that of the concentration exponent of mereuric ehloride which was found to have the following values in various cases:

0.25 Alfred Müller, 1920, with anthrax spores;

0.5 Gegenbauer, 1921, with Staph. aureus;

3.8 Chick, 1908, with Bact. typhosum;

4.9 Chick, 1908, with anthrax spores.

It seems er rtain that, with this compound, different amounts of organic matter in the test solution are responsible for different values of $n$. If in one case the proteins of the medium precipitate $90 \%$ of the $\mathrm{HgCl}_{2}$ present, while in another they precipitate $10 \%$, the values of the concentration coefficient must necessarily be very different.

Another unsettled point is the degree of specificity of the organisms. Different bacteria might give different concentration exponents with the same disinfectant. The only systematic research known to the author on this subject is that eited in the middle section of Table 15 . There are differences between the exponents obtained with Bact. typhosum and Staph. aureus, but they are not consistent.

\section{TEMPERATURE AND DISINFECTION}

The preceding chapter bears out the general assumption that disinfection is the result of a chemical reaction of measurable velocity. Such reactions are usually affected by changes in temperature. The rate of most chemical reactions inereases when the temperature rises, and so does the death rate. The increase in rate differs with the type of chemical reaction, and a quantitative determination of the effect of temperature on disinfection is therefore important in the search for the "lethal 
reaction". A temperature coefficient of disinfection similar to that of chemical reactions excludes any theory of disinfection based on rates of diffusion, e.g., that by Henderson Smith, 1921ํㅡㄹ because the temperature effect on diffusion is much smaller than that on most chemical reactions.

Most biologists are probably more familiar with the conception of temperature coefficients thin with that of temperature increments, and therefore temperature coefficients will be used throughout this discussion, though the increments would be preferable since they remain constant while the temperature coefficients decrease slightly with increasing temperature.

Temperature coefficients of disinfection have been determined by Madsen and Nyman (1907), by Chick (1908 and 1910), by Paul, Birstein and Reuss (1910), and by many others. Table 16 lists some of the more recently determined values of the temperature coefficient when disinfection was accomplished by various means (by alcohols, Tilley, 1942; by chlorine, Charlton and Levine, 1937 ; and by high acidity, Cohen, 1922).

A simple relation exists between temperature coefficients and death times. If the deathrate constant increases $Q_{1}$ times for every degree increase in temperature, and if $K$ is the constant at the temperature $T$, then the constant at the temperature $T+N$ is $K Q_{1}{ }^{x}$ and the formula for death at this temperature is

$$
\mathrm{KtQ}_{1}{ }^{\mathrm{N}}=\log \frac{\text { initial number }}{\text { survivors }}
$$

In any set of experiments to measure death times, the values for $K$, initial number and survivors are the same, and we have the simple relation

$$
\mathrm{tQ}_{1}{ }^{\mathrm{N}}=\text { constant }=\mathrm{A}
$$

and therefore, $\mathrm{N} \log \mathrm{Q}_{1}=\log \mathrm{A}-\log \mathrm{t}$.

This indicates that a straight line will be obtained if the

1. See p. 35 . 
TABLE 16

Temperature coefficients of disinfection

I. Disinfection by various alcohols. (From Tilley, 1942)

\begin{tabular}{|c|c|c|c|c|c|c|c|}
\hline \multirow{2}{*}{ Disinfectant } & \multicolumn{3}{|c|}{ Bact. typhosum } & \multicolumn{4}{|c|}{ Staph. aureus } \\
\hline & $10-20^{\circ}$ & $20-30^{\circ}$ & $30-40^{\circ}$ & $10-20^{\circ}$ & $20-30^{\circ}$ & $30-40^{\circ}$ & $40-50^{\circ}$ \\
\hline Phenol & 5.8 & 8.3 & 8.4 & 5.1 & 3.9 & 4.0 & 7.4 \\
\hline Ortho-cresol & 6.6 & 5.1 & 6.9 & 5.4 & 4.2 & 4.3 & 10.0 \\
\hline Para-cresol & 6.1 & 5.8 & 5.6 & 4.3 & 4.1 & 4.4 & 9.0 \\
\hline Resorcinol & 7.1 & 7.1 & 8.8 & 3.1 & 3.2 & 4.4 & $\ldots$ \\
\hline Ethyl alcohol & $\ldots$. & 43.0 & 54.0 & $\ldots$ & 13.0 & 9.0 & .... \\
\hline$n$-Butyl alcohol & $\ldots$. & 31.0 & 40.0 & $\ldots$. & 11.0 & 9.0 & .... \\
\hline
\end{tabular}

II. Disinfection by chlorine at various acidities. (From Charlton and Levine, 193\%)

\begin{tabular}{c|c|c|c}
\hline \multirow{2}{*}{$\mathrm{pH}$} & \multicolumn{3}{|c}{ Bacillus metiens } \\
\cline { 2 - 3 } & $25-36^{\circ}$ & $35-45^{\circ}$ & $45-55^{\circ}$ \\
\hline \multirow{2}{*}{6.0} & 6.1 & 5.4 & 5.4 \\
8.7 & 3.7 & 3.1 & 3.5 \\
\hline
\end{tabular}

III. Disinfection by high acidity, at pH 3.5. (From Cohen, 1922)

\begin{tabular}{c|c|c|c|c|c}
\hline \hline \multicolumn{3}{c|}{ Bact. coli } & \multicolumn{2}{|c}{ Bact. typhosum } \\
\hline $0-10^{\circ}$ & $10-20^{\circ}$ & $20-30^{\circ}$ & $0-10^{\circ}$ & $10-200^{\circ}$ & $20-30^{\circ}$ \\
\hline 2.1 & 4.4 & 3.8 & 1.6 & 1.5 & 1.8 \\
\hline
\end{tabular}

logarithms of the death times are plotted against temperature. Figure 18 shows a few of Chick's data plotted in this way. The curves representing the different phenol concentrations are nearly parallel, indicating the same $\mathrm{Q}_{10}$, whereas the curve for $\mathrm{Ag}^{\mathrm{N}} \mathrm{N}_{3}$ has a different slope, which means that the reaction has a different $Q_{10}$.

For practical purposes, it is customary to determine which concentrations will produce the same degree of sterilization at different temperatures. McCulloch (1936) found that Bact. typhosum will be killed in 10 minutes at $2^{\circ}$ by $2.0 \%$ phenol, at $20^{\circ}$ by $1.18 \%$ and at $40^{\circ}$ by $0.56 \%$. 
From such data the temperature coefficient can be determined if the concentration exponent is known. The equation is

$$
\mathrm{Kt}_{1} \mathrm{c}_{1}{ }^{\mathrm{n}}=\mathrm{K} \mathrm{t}_{2} \mathrm{c}_{2}{ }^{\mathrm{n}} \mathrm{Q}_{\mathrm{N}}
$$

where $Q_{\mathrm{N}}$ is the temperature coefficient for the interval $N$ in degrees centigrade. For equal disinfection times, we have

$$
\mathrm{Q}_{\mathrm{N}}=\left(\frac{\mathrm{c}_{1}}{\mathrm{c}_{2}}\right)^{\mathrm{n}}
$$

In the above example, assuming $n=6$, we find from 20 to $40^{\circ}$,

$$
\mathrm{Q}_{20}=(1.18 / 0.56)^{6} \text { or } \mathrm{Q}_{10}=(1.18 / 0.56)^{3}=9.3 .
$$

For the interval from 2 to $20^{\circ}$,

$$
\mathrm{Q}_{18}=(2 / 1.18)^{6} \text { or } \mathrm{Q}_{10}=1.695^{6 / 18}=5.8 \text {. }
$$

When $n=1$, the ratio of concentrations equally efficient at different temperatures equals the temperature coeffi-

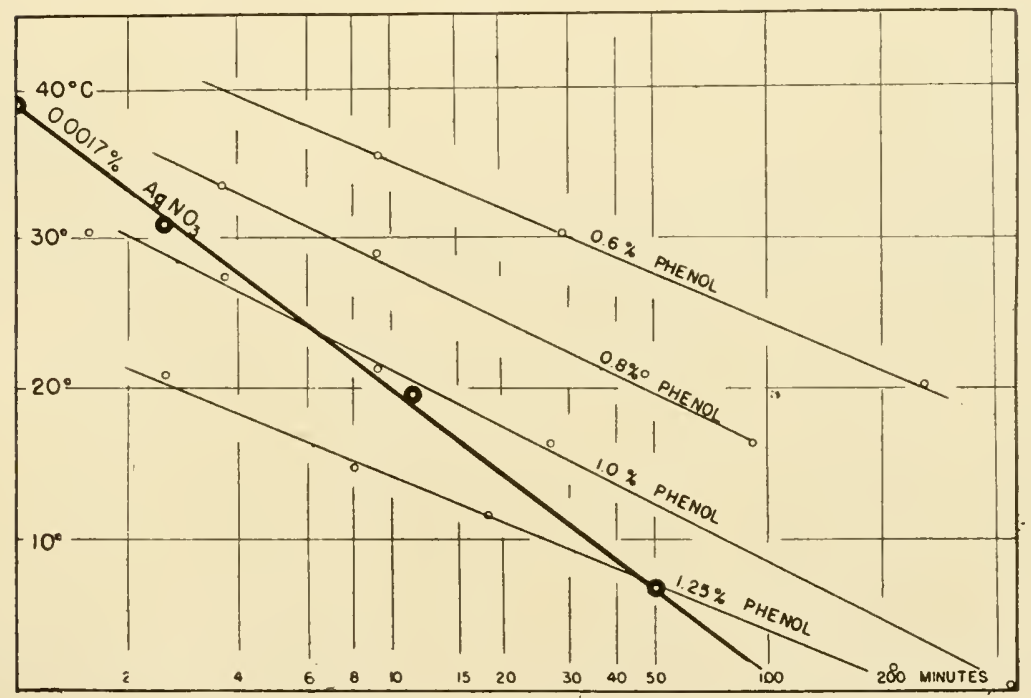

Fig. 18. Effect of temperature on the death time of Bacterium paratyphosum treated with phenol. Abscissa: death time, on logarithmic scale; ordinate: temperature. (From data of Chick, 1908.) 
cient. MeCulloch found for formaldehyde $(n=1)$ the following concentrations equally efficient: At $2^{\circ}, 5 \%$; at $20^{\circ}, 2.5 \%$; and at $40^{\circ}, 0.5 \%$. This gives $\mathrm{Q}_{18}=2$ and $\mathrm{Q}_{20}=5$, and consequently $\mathrm{Q}_{10}=1.5$ and 2.2 respectively for the two different intervals.

The large majority of experiments on the role of temperature in disinfection indicate that the effect is similar to that on chemical reactions. The temperature coefficients average about 2. Often they are very much high. er. Rarely are they consistently less than 2, and if so, this also can usually be explained on the basis of a chemical phenomenon, as in the case of alkali whose action is not affected much by temperature.

The general trend of results is thus in conformity with the explanation that disinfection is due to a chemical reaction of the disinfectant with some cell constituents. It excludes the explanation of the logarithmic order by a graded rate of diffusion because a temperature increase of 10 degrees would certainly not be sufficient to double the rate of diffusion. But some observations have been recorded which remain mexplained, as e.g., the higher temperature coefficient of very young cells as compared with old ones (Chick, 1910). A careful study in the light of the latest knowledge of temperature effects in biology seems necessary to clarify the role of temperature disinfection.

TEMPERATURF COEFFICIENTS OF LIFE AND DEATH

The above-mentioned experiments on the influence of temperature on death processes contain a fact of importance for the interpretation of temperature effects on life processes. Most organisms cease to grow when their temperature is lowered to a few degrees above the freezing point of water or cell sap. This cessation of growth is not abrupt. If growth ceases at $5^{\circ}$, it is still exceedingly slow at $10^{\circ}$ and not very rapid at $15^{\circ}$. The temperature coefficient between 0 and $5^{\circ}$ is infinite, between 
5 and $10^{\circ}$ it may be 5 to 8 , between 10 and $15^{\circ}$, about 3 to 4 , and it thus gradually approaches the value of 2 to 3 which we find near the optimal temperature. The energyfurnishing processes behave similarly. Although enzymes continue to function below the minimal temperature of growth, down to the freezing point (Foter and Rahn, 1936; Rahn and Bigwood, 1939), their temperature coefficients increase greatly near the freezing point.

Quite contrary to growth rate, death rate displays a fairly uniform temperature coefficient as far down as the freezing point. While the number of experiments on record on that subject is not great ${ }^{1}$, there is no instance showing an increase similar to that of the life functions. Death proceeds more slowly at lower temperatures, but the decrease of the rate is very slight, its $Q_{10}$ is about the same as at 20 or $30^{\circ}$, and not several times as large, as we find it with growth and fermentation. The state of dormancy induced by low temperature does not interfere with death by chemical poisons.

Since death is a destruction of the mechanism of growth or cell division, the constancy of the temperature coefficient indicates that the essential molecules involved in this mechanism are not impeded much by low temperatures in their reactivity with poisons, while they are impeded in their reactivity with metabolites. This is important for the explanation of the great retardation or complete inhibition of growth and energy production of the cell.

One of the several theories offered to account for this phenomenon is that of an increase in viscosity of the protoplasm. According to Belehradek (1935, p. 160), "such an increase would considerably hinder free movements of reacting molecules with the result that the biochemical reactions in the cell would be brought to a standstill." But the hindering of free movement of re-

1. See Table 16. 
acting molecules should also apply to those of the disinfectants. As the latter are evidently not hindered at all, and as the increased viscosity of protoplasm does not influence appreciably the death rate, it does not seem likely that it should influence the growth rate and therefore, it is probably not the cause of the cessation of life functions at low temperatures.

\section{INTERFERENCE OF FOREIGN MATTER WITH DISINFECTION}

Sterilization of water supplies and sterilization of instruments are perhaps the only cases where bacteria are exposed to disinfectants in the absence of organic matter. In most cases of disinfection, proteins are present, and frequently other organic or inorganic substances. It is important, therefore, to know to what extent foreign matter interferes with sterilization.

It has been stated before that probably all disinfectants produce their killing effects by reacting with some protein in the cell. They must be expected to react also with proteins outside the cell. Obviously, disinfectants will be weakened, or their action may even be completely nullified if they produce insoluble compounds with foreign materials. Such is the case for silver nitrate in presence of chlorides, for mercury salts in presence of hydrogen sulfide, and for hydrogen peroxide in open wounds, where it is decomposed by catalase.

A particularly important instance is that of the disinfection of the living body in chemotherapy where the compounds of the blood and of the tissues may tend to combine with the toxic agent, thereby decreasing its concentration and efficiency.

Different disinfectants will be affected differently by the same foreign substance, and this is one of the reasons why so many different kinds of disinfectants are being used. 
Chick and Martin (1908) made some experiments on the interference of proteins with disinfection. They found that phenol was not much affected by $10 \%$ blood serum. In the average of 4 experiments, the concentration of phenol had to be increased only from 0.806 to $0.924 \%$ to accomplish sterilization in 15 minutes. Expressed in terms of death time, this would mean $15(0.924 / 0.806)^{6}=34$ minutes, an increase of $125 \%$, which is relatively little. Mercuric chloride $(0.05 \%)$ was considerably more weakened by blood serum, as shown in the following table:

Conc. of blood serum (per cent) : $\begin{array}{lllll}0 & 5 & 10 & 20 & 30\end{array}$ Death time (in minutes): $\quad \begin{array}{rrrrr}7.2 & 10 & 14.2 & 39 & 62\end{array}$ Per cent increase in death time: $\begin{array}{lllll}0 & 39 & 97 & 340 & 760\end{array}$ Animal charcoal interfered especially with emulsified disinfectants. Dried feces acted partly chemically, partly by adsorption.

Many disinfectants have been tried in the presence of organic matter, serum, blood, milk, mine, feces, etc., but usually only the phenol coefficients are recorded and this gives very little information on interference by foreign matter because the phenol coefficients include the effect of organic matter upon phenol as well as mpon the disinfectant under test.

Our own data with skimmed milk diluted 1:10 show for phenol, formaldehyde and hydrogen peroxide a prolongation of the death times by about 20 to $35 \%$ while, with mercuric chloride, the prolongation was about $1000 \%$ and with mercurochrome, 10,000\%. Washed bacteria were used in these experiments in order to exclude all foreign matter from the controls. With the customary method of placing 0.5 ce. of the bacterial culture into 5 cc. of disinfectant, a considerable amount of organic matter is introduced, namely, $1500 \mathrm{ppm}$. of peptone and meat extract. This is sufficient to interfere with strong disinfectants capable of killing bacteria in very low concentrations. The difference of procedure explains the 
great difference between the results of our own experiments and those by Chick and Martin, with $\mathrm{HgCl}_{2}$. These authors measured the weakening effect of blood serum not by comparison with water, but by comparison with a solution of about $0.15 \%$ meat extract plus peptone, which eliminated a good portion of the mercury ions, while in our controls no protein was present except that of bacterial cells.

The efficiency of chlorine and iodine is greatly decreased by very small amounts of organic matter. For city water supplies, 0.2 to $0.5 \mathrm{ppm}$. of chlorine is sufficient to bring about rapid sterilization while 7 to 10 ppm. is the amount ordinarily used for sewage, which contains only $600 \mathrm{ppm}$. of foreign matter, less than is present in the medium used for the determination of the phenol coefficient.

The $\mathrm{H}$ and $\mathrm{OH}$ ions are very important foreign substances. Some disinfectants and antiseptics act very differently at different $\mathrm{pH}$ values. In general, however, with strong disinfectants, the effect of a change in $\mathrm{pH}$ is not very great. There is only one strong disinfectant which shows a very great response to changes in acidity, namely chlorine. Some antiseptics are made absolutely harmless by a change in $\mathrm{pH}$. This is especially true with such compounds as benzoic, salicylic, and sulfurous acids, which are efficient only at low $\mathrm{pH}$, and also with the dyes, all of which will be discussed in detail later.

\section{INTERFERENCE OF ANTIDOTES WITH DISINFECTION}

Antidotes are not employed very often in man's struggle with bacteria. When chemical compounds are used to kill bacteria, either they can be removed by simple rinsing (skin, instruments), or the sterilized materials are discarded afterwards (excreta, dead animals). For materials to be nsed after sterilization disinfection by 
heat has many advantages (e.g., in foods). However, there are cases in which heat camnot be used, as in the sterilization of certain foods, or of eatgut, and in chemotherapy.

An example of the use of disinfectants in foods and of the subsequent removal by an antidote is the experimental sterilization of milk for cheese making by hydrogen peroxide which is later destroyed by catalase. This method has been used by Curran, Evans and Leviton (1940) in the study of bacteriology of cheese ripening. Another example is the use of $\mathrm{SO}_{2}$ in the fermentation industries. The antidote in this case is atmospheric oxygen which very slowly oxidizes the $\mathrm{SO}_{2}$ to sulfuric acid which at these great dilutions is harmless.

In ehemotherapy the entire body may act as an antidote. Concerning the role of the body, however, a distinction should be made between two ver'y different modes of action, namely, a chemical combination between the disinfectant and some components of the body, and a mere dilution eaused by partial elimination of the poison. Only in the first ease can we really speak of the body reacting as an antidote.

The difference between these two modes of action is well illustrated by the experiments of Gegenbauer which will be discussed a few pages below. Staphylococei treated with $\mathrm{HgCl}_{2}$ could be made to multiply again - by repeated washing with water if the exposure had not been longer than one hour. After long exposures, washing did not result in reeovery, but an antidote producing an insoluble compound was capable of making the bacteria multiply again.

Washing or diluting camnot repair injury. Such operations can only remore eonditions which prevent the functioning of the uninjured cell meehanisms; they remove, so to speak, the "monkey wrench" from the engine. This is illustrated by the fact that most bacteria, 
though they camot multiply in acid media, such as cider, are however not killed, and start to multiply as soon as the acid is neutralized. (The production of this type of "suspended animation" is usually called antisepsis.) The antidote does more than washing or diluting, it repairs the primary injury done by the disinfectant to the cell mechanism, but not the further injury resulting from the abnormal or interrupted functioning of the injured mechanism. When this secondary injury has advanced so far as to be irreparable, the cells cannot be revived by the antidote.

The application of disinfectants to wounds must be considered from this viewpoint. It has been shown that bacteria, affected chemically to the point where they cannot multiply in broth, may still cause infection when injected in animals. The rapid circulation of liquids in the body results in a washing of the bacteria. Besides, certain compounds of the blood or tissue juices may diffuse into the bacterial cell and react chemically with the disinfectant therein.

\section{PROPERTIES OF VARIOUS GROUPS OF DISINFECTANTS}

It is not our purpose in this discussion to describe the effect of each bactericide, or the advantages and disadvantages of its use in various applications. Such descriptions will be found in medical handbooks (see, for example, "Disinfection and Sterilization" by McCulloch). We are concerned here mainly with the nature of the lethal reaction.

1. A c ids. Strong mineral acids act essentially by their hydrogen ions. Krönig and Paul demonstrated this in their classical study on the physical chemistry of disinfection (1897), in which they found that most of the strong acids kill bacteria at approximately the same rate when diluted to the same normality. (Since many 
bacteria will die at $\mathrm{pH} 2$, which means $10 \mathrm{mg}$. H ions per liter, or 10 ppm., hydrogen ions must be considered very efficient disinfectants.)

In a few cases, however, such as that of $\mathrm{HNO}_{3}$ and $\mathrm{HF}$, not only the $\mathrm{H}$ ions but the anions also act on proteins; the death rate then is higher than the $\mathrm{pH}$ would indicate. With weak organic acids such as benzoic and salicylic, the undissociated molecule itself is toxic. The same is true for $\mathrm{SO}_{2}$ (see p. 159). The strongly dissociated $\mathrm{CCl}_{3} \mathrm{COOH}$ acts by its anions as well as its cations.

The effect of $\mathrm{pH}$ on the colloidal state of protein is well known, and denaturation by a high concentration of hydrogen ions is to be expected, provided that the acidity of the medium can affect the $\mathrm{pH}$ of the cell contents. But different proteins have different isoelectric points, and a wide range of different responses to $\mathrm{pH}$ changes is not surprising. In fact some yeasts as well as some Aspergilli can multiply at $\mathrm{pH} 2.0$; certain sulfuroxidizing soil bacteria are known to exist even at $\mathrm{pH} 1$ (Starkey and Waksman, 1943), while some mrea-splitting bacteria grow best at $\mathrm{pH} 8.5$ to 9.0 .

2. Altialies. Alkalies are commonly used as bactericides especially in soaps and washing powders. It has been shown that some componnds like trisodium phosphate, sodium metasilicate, and slaked lime act largely in proportion to their hydroxyl ions (Myers, 1928 and 1929, Tilley and Schaffer, 1931). But the tolerance for these ions varies greatly with the species. The lethal action is usually explained by the prompt denaturation of proteins by excessive alkali.

3. II e a vy M etal Compounds. Krönig and Paul (1897) proved that heavy metal salts act primarily by their metallic ions. These anthors decreased the ionization of $\mathrm{HgCl}_{2}$ by the addition of $\mathrm{NaCl}$, and showed that, as the concentration of the latter was increased, the efficiency of the mercury salt decreased. 
An extensive study of the mechanism of mercuric chloride disinfection was made by Gegenbauer (1921). $\mathrm{He}$ found that $\mathrm{HgCl}_{2}$ is not only adsorbed on coagulated serum proteins, but that it is also dissolved in them, and that it can be washed out again. Besides, an insoluble mercury proteinate is formed which camnot be washed out, but the normal protein can be restored upon the addition of $\mathrm{H}_{2} \mathrm{~S}$ which forms $\mathrm{HgS}$. Gegenbauer then applied these findings to Staphylococci. When the cells had remained for an hour in a solution which contained as much as $2 \% \mathrm{HgCl}_{2}$, they would grow if repeatedly washed with water. But after 2 hours of exposure they could not usually be revived by washing. However, when the antidote $\mathrm{H}_{2} \mathrm{~S}$ was applied, bacteria from a $2 \% \mathrm{HgCl}_{2}$ solution could be brought back to life after 6 hours, but not after 11 hours. With $0.1 \% \mathrm{HgCl}_{2}$, the cells became viable upon $\mathrm{H}_{2} \mathrm{~S}$ treatment even after 36 hours. The results are shown in Figure 19.

According to Gegenbauer, the actual poisoning proceeds in three stages: first, the bichloride of mercury dissolves fairly rapidly in the protoplasm of the Staphylococci and probably interrupts all cell functions. This proceeds according to a definite partition coefficient. Then a slower process begins, the formation of a mercury proteinate. While the first process can be reversed by washing, the proteinate cannot be removed by washing, and after about 2 hours, its formation has gone so far that in every cell some vital protein has been changed. This process, however, becomes reversible on the addition of $\mathrm{H}_{2} \mathrm{~S}$, though only within a limited time. Therefore, we must assume a third reaction, namely the destruction of some essential life function. Either some catabolic process is accelerated by mercury, or the mercury proteinate itself may undergo a further change which is irreversible. The rate of this third process is approximately proportional to the square root of the mereury concentration. 


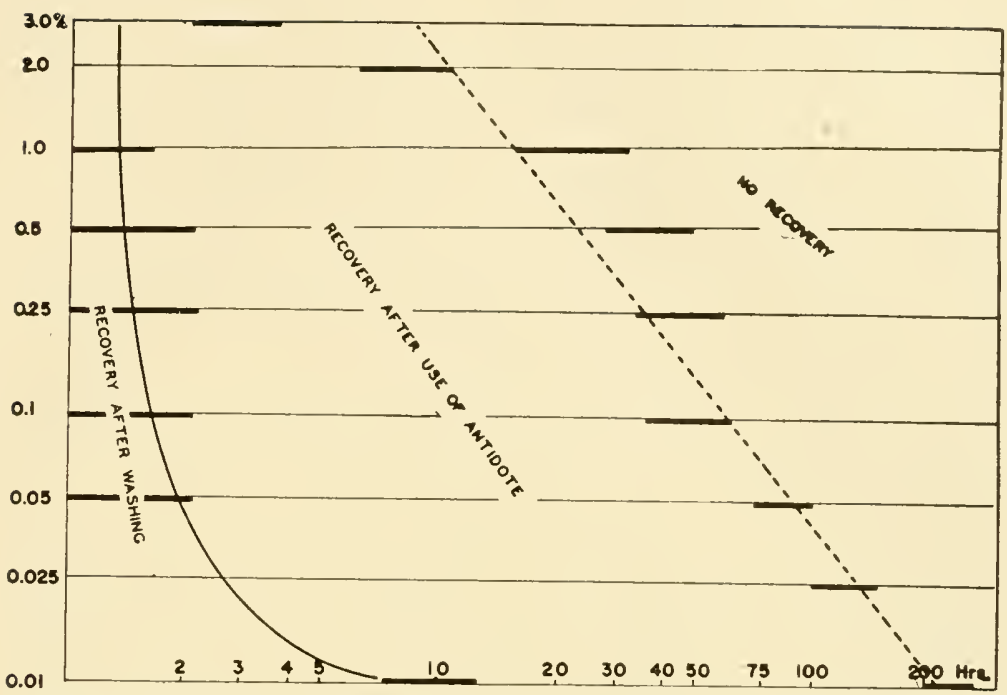

Fig. 19. Relation between the concentration of $\mathrm{HgCl}$, and the time during which staphylococci can be exposed to that disinfectant and still recover. The curve at the left indicates the limits of recovery after washing, the curve at the right, the limits of recovery after use of $\mathrm{H}_{2} \mathrm{~S}$ as antidote. Abscissa: time in hours, on logarithmic scale; ordinate: percent concentration on logarithmic scale. (From data of Gegenbauer, 1921.)

Many orgunic mercury compounds have been tested in the hope of finding disinfectants which are less toxic and less irritant to mammals than the bichloride. Some of these newer disinfectants are in fact more powerful than the bichloride against bacteria and relatively less toxic to the hosts. Their use, however, is not as general as that of the inorganic compounds, because the properties of the organic radicals affect the chemical behavior of the compounds. This is exemplified in the great dependence of the effect of mercurochrome upon the acidity of the substrate (a phenomenon which is typical of all dỵes and therefore is not surprising in mercurochrome).

Other organic mercury compounds are highly selective, like metaphen, merthiolate and phenyl-mercuri-nitrate. These three compounds are stronger disinfectants than the bichloride of merenry-merenrochrome is not.

The organic mercury compounds have no mercury ions, 
and no suggestions have been made concerning their mode of action.

The only other heavy metal compounds used extensively as disinfectants are those of silver. The silver salts, nitrate, lactate, and citrate, act probably through their metallic ion, as in the case of the mercury salts. Their instantaneous reaction with chlorides to form insoluble $\mathrm{AgCl}$ limits their usefulness greatly.

The preparations of silver metal in colloidal form, with trade names like argyn, argyrol, solargentum, silvol, etc., are of particular interest. Metallic silver does not react with chlorides or proteins as silver ions do, but it is only a very weak disinfectant. According to Leonard (1931), a suspension containing as much as 1 gram of colloidal silver in 100 ce. does not kill the test organisms Bact. coli and Staph.aurcus, though suspensions of 1 gram in 10,000 are sufficient to prevent multiplication.

This leads us to the problem of the oligodynamic action of metals which is still much debated. The first observations were made with metallic copper whose disinfecting action has been proved by several investigators. The lethal effect cannot be due to copper ions going into solution from the metal because the solubility of metals is immeasurably small, and a corresponding amount of copper ions from any copper salt has not the least inlibiting effect. Even a solution of 5\% copper chloride does not kill Staphylococcus aureus in one hour.

If direct contact of the cells with the metal were necessary to bring about death, the latter might be explained by a chemical combination of some essential cell constituent with the metal, or by a physical action, such as interference with some electric potential in the cell. However, no conchusive proof has been given that direct contact is necessary.

Most experimenters agree that oxygen is necessary to bring about the lethal effect of metallic copper sur- 
faces. This suggests a chemical rather than a physical effect, perhaps the formation of a peroxide. But the amounts of hydrogen peroxide formed on metal surfaces in water by oxygen are far too small to explain the oligodynamic action. However, a combined action of peroxide and metal ions may be sufficient to kill bacteria. Dittmar, Baldwin and Miller (1930) had observed that the lethal action of hydrogen peroxide is speeded up nearly 100 times by the presence of 0.1 millimoles of $\mathrm{Cu}^{++}$and $\mathrm{Fe}^{+++}$ions. With $6 \mathrm{mg}$. $\mathrm{Cu}^{++}$per liter, Staph. aureus was killed in 10 minutes by $0.025 \%$ $\mathrm{H}_{2} \mathrm{O}_{2}$, and in 30 minutes by $0.008 \% \mathrm{H}_{2} \mathrm{O}_{2}$.

The use of silver surfaces has been proposed to sterilize water and even milk. Bechhold (1918) coated particles of coal and sand with a thin layer of silver and used them for the sterilization of water. Krause and Bergmann (1928) produced the so-called "katadyn" by turning molten silver into a fine foam. The crushed solidified foam bubbles are claimed to disinfect water upon contact. The results obtained with milk, however, are not very encouraging.

Colloidal silver differs from these silver preparations only in having a mnch larger surface. No records could be found which would throw light on the important question whether oxygen is necessary for the disinfection by colloidal silver preparations.

4. $T h e A l c o h \circ l s$. Of the aliphatic alcohols, only ethyl alcohol is used as a disinfectant, and it is rather weak. Its strongest action is at a concentration of $70 \%$. Absolute alcohol is less effective because it is dehydrating, and proteins withont moisture are not easily denatured.

The rate of denatmation of different native proteins by ethyl alcohol varies greatly. Some enzymes lose their activity in alcoholic solutions rather slowly.

A surprisingly ligh concentration exponent was found by Tilley for ethyl alcohol (Table 15). 
Of the cyelic alcohols, phenol is the best known, but the cresols, thymol, resorcinol, etc., are even stronger disinfectants than phenol. One of the early attempts at explaining the action of phenol is that of Reichel in 1909. He showed that phenol dissolves in coagulated serum albumin, and that the fraction of phenol going into the albumin can be increased by the addition of salt. Salt also increases the disinfecting power of phenol, and the death times with various $\mathrm{NaCl}$ concentrations increase in proportion to the partition coefficient of phenol between water plus salt, and albumin.

This not only explains the effect of the salt, but proves that the lethal action is brought about only by the protein-dissolved fraction of the phenol. The lethal reaction itself remains unknown. Denaturation would be the simplest assumption, but we know that some proteins are not readily denatured by the higher alcohols. Phenol and thymol are frequently used in experiments with enzymes to prevent bacterial action; the denaturation of enzymes (which are proteins) by these compounds must therefore be very slow. Of course, this refers only to dilute solutions, and their rate of disinfection (and perhaps of denaturation generally) increases as the 6 th or 7 th power of the concentration. A doubling of the concentration would make denaturation $2^{6}=64$ times as rapid. As stated above (p. 72) the high concentration exponent and its change with temperature make it appear possible that phenols are merely catalysts speeding up some natural deterioration which is normally so slow as to be balanced by the cell's repair mechanism.

5. Formaldehyde. Formaldehyde is the only aldehyde known to have a strong disinfectant power, though not for all organisms; molds are not very sensitive to it. It has one outstanding property, namely, it retards multiplication in very great dilution (see p. 129). 
Formaldehyde reacts very promptly, with the amino groups of proteins. (This reaction is used in the quantitative determination of amino groups.) Naturally, such proteins are then incapable of any physiological function.

6. Oxidizing Agents. The two best known oxidizing compounds are hydrogen peroxide and permanganate. They react very differently, however. Peroxide does not attack proteins or other organic matter readily, but in tissues it is destroyed by the catalase. It is a somewhat more efficient disinfectant than formaldehyde, and resembles the latter by acting proportionately to its concentration, the concentration exponent being approximately 1 . Permanganate reacts promptly with organic matter, changing to the inert brown $\mathrm{MnO}_{2}$ and thereby losing its efficiency. In pure water, it is more efficient than peroxide, but its usefulness is greatly limited whenever organic matter is present. The concentration exponent of permanganate is approximately 4, indicating a rapid loss of power by dilution.

The lethal reaction with hydrogen peroxide is probably an irreversible oxidation of some vital protein. This oxidation is not due to nascent oxygen liberated by the catalase in the bacterial cells, for the streptococci and lactobacilli which do not contain catalase are nevertheless killed by peroxide.

The rate of oxidation of various chemical substances by hydrogen peroxide is greatly accelerated by the simultaneous presence of small amounts of $\mathrm{Fe}^{+++}$and $\mathrm{Cu}^{++}$ions, and Ditimar, Baldwin and Miller (1930) found this to be true also for disinfection. With 0.1 millimol each of $\mathrm{Fe}_{2}\left(\mathrm{SO}_{4}\right)_{3}$ and $\mathrm{CuSO}_{4}$, the phenol coefficient of hydrogen peroxide increased with Bact. coli from 0.014 to 1.4 , and with Staph. aureus from 0.012 to 1.2. A combination of potassium dichromate with cobaltous or manganous sulfate produced the same result. 
As to permanganate and chromate, their reaction with organic compounds is so ubiquitous that it is impossible to point to any specific reaction as the cause of death.

7. The Ha $l$ og $e n s$. Chlorine and iodine resemble permanganate in their very rapid reaction with many different organic compounds, but they are far more powerful disinfectants than permanganate. They are used widely : chlorine in the disinfection of water supplies (which contain practically no organic matter to weaken its action) and iodine extermally, in medical practice, mostly as a skin disinfectant. Their reaction with organic matter is so great that the phenol coefficient, which is about 200 when determined in the ordinary way, with $1 / 2$ ml. of culture, rises to 2,000 when determined with washed bacteria (see p. 110).

Chlorine disinfection has several unusual features. One is its great sensitivity to $\mathrm{pH}$. The data by Tilley and Chapin, 1930 (Table 17) will illustrate this. According to Holwerda (1928) the sensitivity to pII can be explained by the reaction of chlorine with water:

$$
\mathrm{Cl}_{2}+\mathrm{H}_{2} \mathrm{O} \longrightarrow \mathrm{HOCl}+\mathrm{HCl}
$$

and

$$
\mathrm{HOCl} \longrightarrow \mathrm{H}^{+}+\mathrm{OCl}^{-}
$$

TABLE 17

Death times of spores of $B$. anthracis treated with chlorine in different buffer solutions. (From Tilley and Chapin, 1930.)

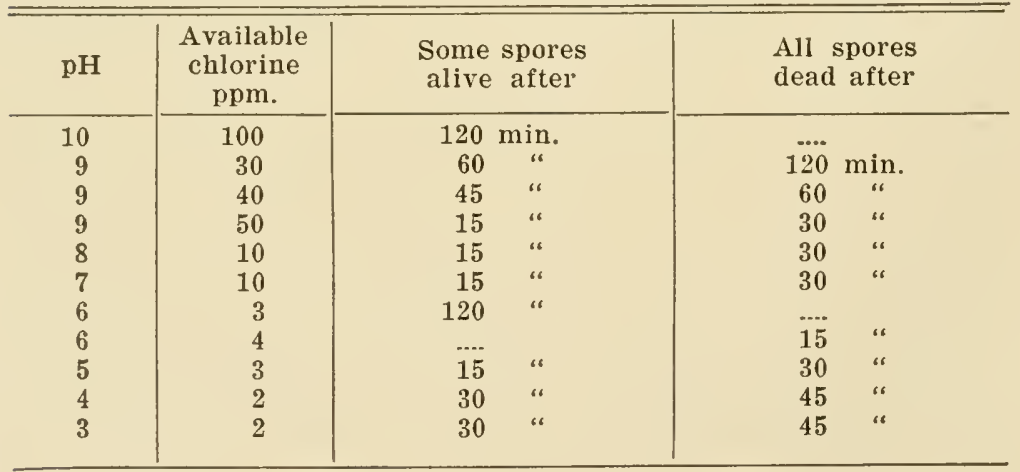


Two dissociation constants of $\mathrm{HOCl}$ are given in chemical literature which differ greatly, namely $3.7 \times 10^{-8}$ and $6.7 \times 10^{-10}$. The latter is supposed to be the more accurate; it certainly comes from a later measurement, but Holwerda based his calculations on the first, older constant. His experimental data ag'ree fairly well with his assumption that the undissociated $\mathrm{HOCl}$ is the toxic part of chlorine dissolved in water. But his experiments were largely limited to alkaline and neutral solutions. The increased efficiency of chlorine by a decrease in $\mathrm{pH}$ from 7 to 3 (Table 17) cannot be explained in this way. The newer dissociation constant does not give as good a correlation as the older one.

Another unusual feature of chlorine disinfection is the non-logarithmic type of survivor curve, as shown previously. Two very extensive investigations, one by Charlton and Levine (1937) and the other by Mallmann and Ardry (1940), bear out this observation. The explanation must be sought in the usual mode of action of chlorine as illustrated in the following case reported by Anderson and Mallmam, in their recent study of the penetrative powers of disinfectants (1943). They observed under the microscope the effect of various disinfectants upon freshly hatched long-tailed strongylid larvae (parasites of horses). Under the action of chlorine "the thin layer of cuticle which forms the tail of the organism dissolved first, followed by a splitting or shredding of the posterior end of the organism, simultaneously with the appearance of bubble-like rupture of the cuticle along the whole length of the organism." The action of phenol was quite different. At a concentration of $1: 100$ it "produced death of the larvae in 45 minutes withont any external changes of the organisms." In their summary, they state: "Chlorine acts only by oxidation, i.e. first destroying the cell surface."

These observations and conclusions speak unequivocally in faror of the explanation of chlorine action pre- 
viously given by the present writer on the basis of theoretical considerations. A fairly large number of molecules of the cell surface must be destroyed to produce an injury from which the cell camnot recover. The theoretical survivor curve when death results from the inactivation of many molecules agrees in every respect with that observed in chlorine disinfection.

No definite value of the concentration exponent of chlorine can be obtained because of the prompt reaction of this substance with so many organic compounds. It can be computed from graphs like that of Figure $20 \mathrm{by}$

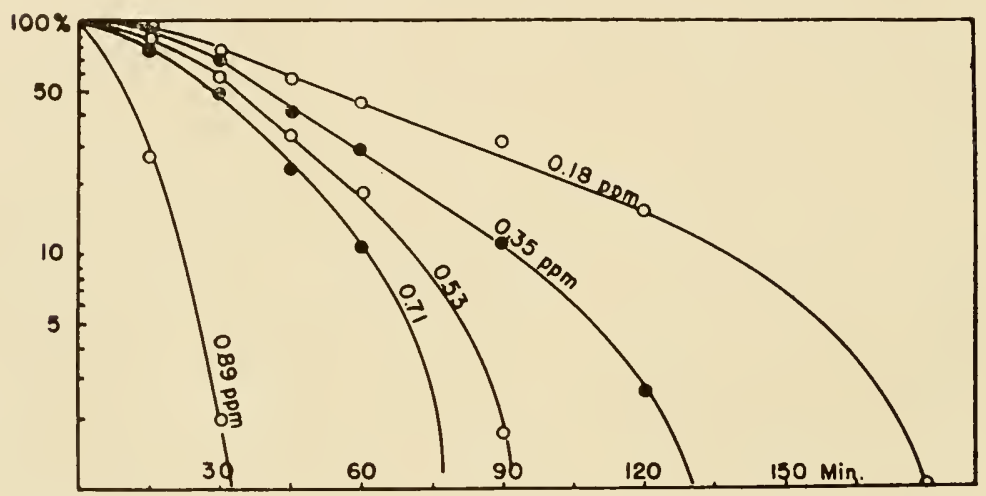

Fig. 20. Semi-logarithmic plot of survivor curves of Bacterium coli treated with chlorine. Alscissa: time of exposure; ordinate: per cent of survivors, on logarithmic scale. (From data of Mallmann and Audrey, 1940.)

estimating the time required to kill the same percentage of bacteria by different concentrations. A horizontal line at $10 \%$ survivors gives different results than one at $1 \%$ survivors. The concentrations in this graph are in the ratios 1:2:3:4:5 the corresponding times to kill $90 \%$ of the cells are $140,92,70,62$, and 22 minutes, and the respective concentration exponents are $1.66,1.61,1.69$, and 0.87. From the times required to kill $99 \%$ of the cells, the concentration exponents are $2.1,1.67,1.70$, and 0.93 . The relation between concentration and death time, from 
the data of Charlton and Levine on the death of spores of B. Metiens is shown in Figure 21.

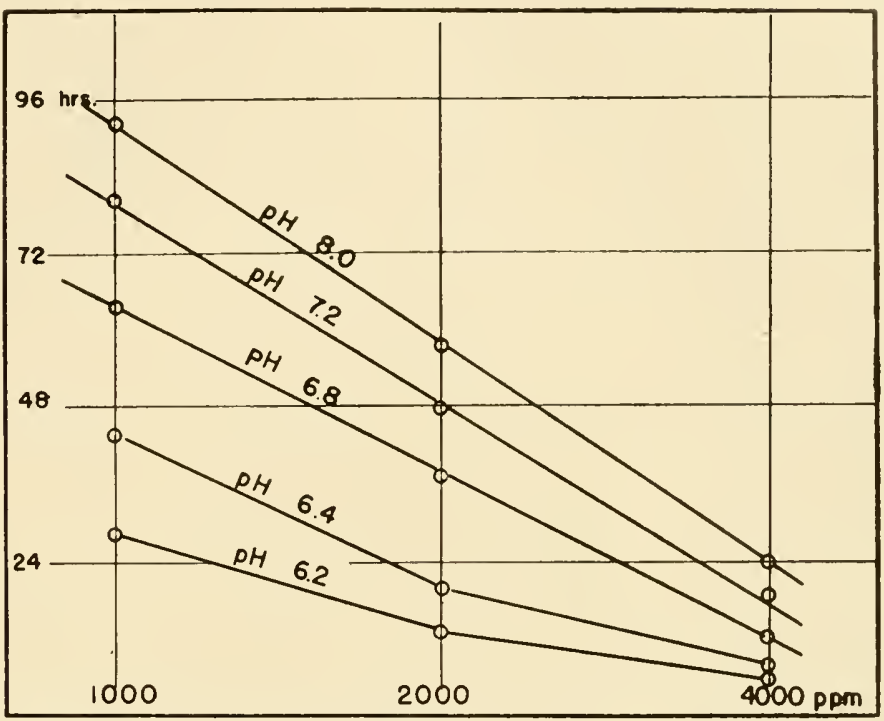

Fig. 21. Relation between chlorine concentration and death time of spores of B. metiens at various acidities. Abscissa: Concentration of chlorine, on logarithmic scale; ordinate: time required to kill $99 \%$ of the spores. (From data of Charlton and Levine, 1937.)

Iodine is used extensively in medicine as a disinfectant. As it is almost insoluble in water, it is applied either in alcoholic solution or in aqueous potassium iodide solution. Strangely enough, no experiments could be found which would permit a calculation of the concentration exponent. Nor has any study of the effect of acidity on iodine disinfection been made, as far as the author is aware. Whether iodine acts as such, or as HOI (corresponding to the $\mathrm{HOCl}$ of chlorine) or as $\mathrm{KI}_{3}$ in the solutions with potassium iodide, is not known.

8. So a ps. The mechanism of disinfection by soaps is rather complicated. Not only does their efficiency depend upon two variable factors, namely, the proportion of the various fatty acids, and the amount of excess alkali, but they have also a highly selective action, lethal 
concentrations occasionally differing a hundredfold between strains of the same species (Tilley and Schaffer, 1930).

Walker (1924) began to unravel this problem by studying first the efficiency of the potassium and sodium salts of each fatty acid; later (1925) he investigated the various soaps from different fats and oils. Outstanding among the components studied was $\mathrm{Na}$ or K laurate which killed pneumococci and streptococei in high dilutions, and also affected typhoid bacteria, but had no action on a strain of Staphylococcus aureus which was completely resistant to all soaps. Klarmann (1933) verified the exceptionally strong effect of lauric acid.

Later, in 1941, Klarmamn and Shternow found capric acid more efficient than lauric. Myristic acid was weaker, though more powerful than palmitic. This held true for all bacteria tested except for typhoid and dysentery bacteria for which palmitic and stearic acids were as toxic as lauric and myristic.

The salts of unsaturated acids (oleic, linolic and linolenic) are highly bactericidal for pneumococci and streptococci, but entirely harmless for typhoid bacteria. Sodium ricinoleate has a marked selective action, which is utilized in the isolation of the colon-typhoid group.

Walker (1925) investigated commercial soaps as well as some he made himself from pure fats. He too found the coconut oil soap, which contains much lauric and myristic acid, superior to all others in killing streptococci and typhoid bacteria (Table 18). In hand-washing; the soap concentration varies from $0.3 \%$ in hasty rinsing to $15 \%$ in prolonged scrubbing of the hands, and can be considered to average about $8 \%$ when the hands are washed thoroughly with the purpose of cleaning them. Thus, while any ordinary soap is sufficient to destroy any adhering streptococci, pnenmococci. and diphtheria bacteria, for typhoid bacteria, coconut oil soap acting for 
3 minutes is necessary. At higher temperatures the efficiency of soaps is considerably increased. Klarmann and Shternow (1941) however, found that typhoid and dysentery bacteria, as well as streptococei, are not completely killed on infected hands by the customary use of soaps in lavatories. But their standard of time differs from that of the previously mentioned investigators.

TABLE 18

Concentrations (in per cent) of neutral soaps required to kill bacteria. (From Walker, 1925.)

\begin{tabular}{|c|c|c|c|c|c|c|c|}
\hline \multirow{3}{*}{$\begin{array}{l}\text { Fat used for } \\
\text { soap }\end{array}$} & \multirow{2}{*}{\multicolumn{2}{|c|}{$\begin{array}{c}\text { Streptococcus } \\
\text { hemolyticus }\end{array}$}} & \multicolumn{3}{|c|}{$\begin{array}{l}\text { Bacterium } \\
\text { typhosum }\end{array}$} & \multicolumn{2}{|c|}{$\begin{array}{c}\text { Staphylococcus } \\
\text { aureus }\end{array}$} \\
\hline & & & \multicolumn{2}{|c|}{$20^{\circ}$} & \multirow{2}{*}{ 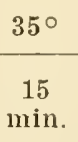 } & \multirow{2}{*}{$\frac{20^{\circ}}{15}$} & \multirow{2}{*}{ 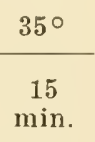 } \\
\hline & $\begin{array}{l}21 / 2 \\
\text { min. }\end{array}$ & $\begin{array}{l}15 \\
\min .\end{array}$ & $\begin{array}{l}21 / 2 \\
\mathrm{~min}\end{array}$ & $\begin{array}{c}15 \\
\text { min. }\end{array}$ & & & \\
\hline $\begin{array}{l}\text { Coconut oil } \\
\text { (Na) }\end{array}$ & 0.31 & 0.16 & 2.5 & 1.25 & 0.62 & $>10$ & $>10$ \\
\hline $\begin{array}{l}\text { Beef tallow } \\
(\mathrm{K})\end{array}$ & 0.62 & 0.16 & $>10$ & 10.0 & 0.62 & $>10$ & $>10$ \\
\hline $\begin{array}{l}\text { Olive oil ( } \mathrm{Na}) \\
\text { Cottonseed oil }\end{array}$ & 0.62 & 0.16 & $>10$ & $>10$ & 1.25 & $>10$ & $>10$ \\
\hline $\begin{array}{l}(\mathrm{Na}) \\
\text { Linseed oil }\end{array}$ & 0.31 & 0.16 & $\ldots$. & .. & 5.0 & . & $>10$ \\
\hline (K) & 0.62 & 0.31 & $>10$ & 10.0 & 0.62 & $>10$ & $>10$ \\
\hline Resin (Na) & 0.62 & 0.62 & 10.0 & 2.5 & 0.62 & 2.5 & 1.25 \\
\hline
\end{tabular}

Walker's results were verified by Tilley and Schaffer (1925) and by Schaffer and Tilley (1930) who, furthermore, showed that a slight increase in alkalinity increased the germicidal action. The effect of organic matter was studied by adling $50 \%$ skim milk which decreased the efficiency of all soaps greatly. According to Eggerth (1927), serum and other proteins decrease the efficiency of soaps while certain lipoids increase it.

Schaffer and Tilley (1930) tested also the effect of additions of phenol, cresol and other disinfectants to soaps 
while Eggerth studied the soaps from substituted fatty acids. He found that $\alpha$-brom fatty acids are more germicidal than the unsubstituted acids (1929), that $\alpha$-hydroxy acids are highly germicidal to some species, but that the substituted compounds have become even more selective than the regular soaps (1930); a similar increase in selectivity was observed with $\alpha$-mercapto and $\alpha$-disulfo soaps (1931).

Of greatest interest to the mode of action of fatty acids and soaps is the effect of $\mathrm{pH}$ which had been emphasized by Eggerth in 1927. Klarmann (1933) measured the amount of various acids required to kill Staphylococcus aureus at $37^{\circ}$ in 2 hours at different $\mathrm{pH}$ values. His results are shown in Fig. 22.

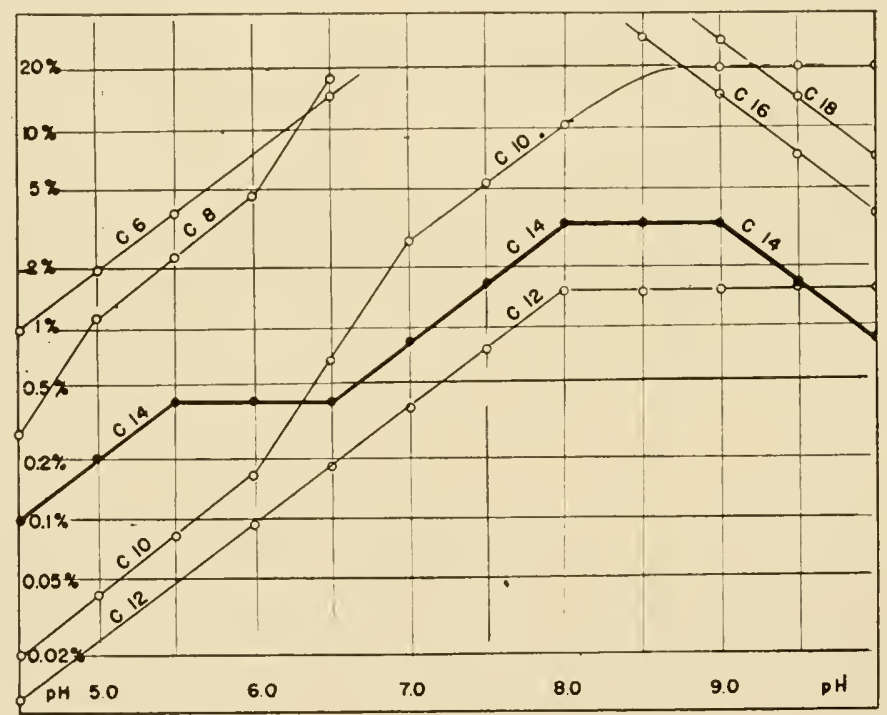

Fig. 22. Concentration of various fatty acids required to kill Staphylococci in 2 hours, at different acidities. Abscissa: $\mathrm{pH}$; ordinate: per cent concentration of the fatty acid, on logarithmic scale. C6: caproic acid, Cs: caprylic acid, C10: capric acid, C12: lauric acid, C14: myristic acid, $\mathrm{C}_{16}$ palmitic acid, C18: stearic acid. (From data of Klarmann, 1933.) 
The lower acids, up to 10 carbons, are efficient only in acid media, at pH 6 or less. In this range, the disinfecting power increases with the molecular weight up to $\mathrm{C}_{12} \mathrm{H}_{24} \mathrm{O}_{2}$, lauric acid. Mrristic acid, $\mathrm{C}_{14} \mathrm{H}_{28} \mathrm{O}_{2}$, is not quite as active in acid media, and the higher acids have no disinfectant properties at all. The fact that the efficiency increases with the acidity indicates that death is bronght about by the undissociated part of the molecule. (For a discussion of this point and for the computation of the undissociated fraction see p. 157). The dissociation constant is $1.8 \times 10^{-5}$ for acetic, $1.5 \times 10^{-5}$ for butyric, and $1.4 \times 10^{-5}$ for caproic and caprylic acid. Klarmann's data show that death is brought about by 40-60 mg. undissociated caproic acid in 100 ce. Assuming 1.4 $\times 10^{-5}$ as dissociation constant for all the higher homologues, the corresponding values for the higher acids are 20-40 mg. for $\mathrm{C}_{*}, 1-1.5 \mathrm{mg}$. for $\mathrm{C}_{10}, 0.2-0.8 \mathrm{mg}$. for $\mathrm{C}_{12}$ and about $2 \mathrm{mg}$. for $\mathrm{C}_{14}$. Pahmitic and stearic acid are so insoluble $\left(0.00092\right.$ and $0.00038 \%$ respectively at $37^{\circ}$ according to Ralston and Hoer', 1942) that they could not be expected to act as disinfectants.

At neutrality, capric, lanric and myristic acids are the only acids capable of killing staphylococei. The lower acids are practically completely dissociated, and the higher acids remain insoluble. But with increasing alkalinity, these latter dissolve, and at pH 9 to 10, palmitic and stearic acid become weak disinfectants and myristic acid becomes stronger again, resembling the higher acirls, while capric acid loses its power entirely.

The detergent properties of soaps have been surpassed by those of new synthetic detergents developed during the last decade. These so-called "wetting agents" are discussed here in comection with the soaps not only because they are substitutes for soap, but also because many of them contain fatty acids. The "cationic detergents" have the fatty acils bound on ammonium derivatives in the cationic part of the molecule, the "ani- 
onic detergents" contain them, often in form of sulfonic acids, in the anion.

Many of the wetting agents are not only detergents, but good disinfectants. Baker, Harrison and Miller (1941 and 1942) found that cationic detergents as a group kill Gram-positive bacteria more readily than Gram-negative species. Of the 9 detergents investigated, all but one killed streptococei, lactobacilli and staphylococei within 10 minutes when diluted $1: 3000$. Two of the 9 failed to kill Bacterium coli and typhosum, three failed with Proteus vulgaris.

The anionic detergents were much less efficient. Eight of them were tested with the bacteria mentioned above, in 1:1000 dilution. After a 10 minutes' exposure, only three had killed the lactobacilli, two had killed the streptococci, and none was powerful enough to kill the two staphylococci; even with 90 minutes exposure, only one of the eight detergents could destroy the stiphylococei. None of these compounds was effective against any of the Gram-negative test organisms.

A rery remarkable phenomenon was observed by Miller, Abrams, Huber and Klein (1943) when cationic detergents were used to disinfect hands. It seems that the detergent deposits on the hands an invisible, non-perceptible film which retains the bacteria under it without killing them, while the outer surface becomes sterile. The film is not easily broken mechanically, e.g., by scrubbing, and hands treated with cationic detergents ean be considered practically sterile for a considerable time. Frequent dipping into saline solution or long rinsing with rumning water tends to deteriorate the film. Soap breaks it up promptly, releasing the viable bacteria underneath. The authors did not offer an explanation for' the different action of the two sides of the film. 


\section{STANDARDIZING OF DISINFECTANTS}

The thorough quantitative studies of disinfectants between 1890 and 1900 made it possible to compare their elliciency, and Rideal and Walker in 1903 proposed to use phenol as the standard of comparison because it is a reliable, not very selective disinfectant that can be obtained chemically pure at reasonable cost anywhere. Their method consisted in inoculating various dilutions of phenol, as well as of the disinfectant under test, with equal amounts of bacteria and determining the death times after transfer into broth. Dilutions of equal death times were compared and their ratio was believed to represent a reliable index of the relative disinfectant actions. Thus a "phenol coefficient" was obtained which told how many times more efficient the substance investigated was than phenol.

This method received a severe jolt when Chick and Martin (1908) showed that the phenol coefficient of sereral common disinfectants varied very much when the death time was changed ( see Table 19). Watson (1908) explained this variation quite simply. Chemical reaction rates are not always proportional to the concentration, but to the concentration raised to a certain power, and, with phenol, the concentration exponent is about 6 . No other disinfectant except the homologues of phenol ${ }^{1}$ has such a high exponent (a list of concentration exponents is given in Table 15). The action of most disinfectants is approximately proportional to their concentration, and the decision to use phenol, with its abnormal concentration exponent, as a standard, was very unfortunate.

Phelps (1911) pointed out that to characterize a disinfectant, we need only to know the death rate and the

1. Concerning the exceptional values for alcohols see p. 68 . 
concentration exponent. They are the only unknowns in the equation

$$
\mathrm{Ktc}^{\mathrm{n}}=\log \frac{\text { initial number }}{\text { survivors }}
$$

The values of $K$ and $n$ elaracterize the disinfeetant far better than the phenol eoefficient, and if the temperature coefficient were also known, the effect of the disinfectant would be known for any combination of concentration, exposure-time and temperature.

TABLE 19

Variation of the phenol coefficient of mercuric chloride with different death times. (From Chick and Martin, 1908.)

\begin{tabular}{l|c|c|c}
\hline \hline \multicolumn{1}{c|}{ Disinfectant } & $\begin{array}{c}\text { Death time } \\
\text { in minutes }\end{array}$ & $\begin{array}{c}\text { Concentration (\%) } \\
\text { required to kill in } \\
\text { that time }\end{array}$ & $\begin{array}{c}\text { Phenol } \\
\text { coefficient }\end{array}$ \\
\cline { 2 - 3 } & 2.5 & 1.20 & \\
Phenol & 2.5 & 0.008 & 13.6 \\
Mercuric chloride & 10 & 1.04 & 173 \\
Phenol & 10 & 0.006 & 550 \\
Mercuric chloride & 30 & 0.990 & 5.0018 \\
Phenol & 30 & & 5 \\
Mercuric chloride & & & \\
\hline
\end{tabular}

Phelps himself did not continue these studies and did not attempt to show with experimental data the practicability of his proposal. In fact, this proposal was never given a thorough test. The idea was dismissed on the ground that the deathrate constant $K$ fluctuates enormonsly. The data obtained by Chick are usually given as proof of that incousistency. The fluctuations are quite large indeed, even when the test is made with the same strain of baeteria, grown in the same medium, at the same temperature, and to the same age. Despite all attempts at uniformity, Chick obtained on different days the following deathrate constants for Bact. paratyphosum exposed to $0.6 \%$ phenol at $20^{\circ} \mathrm{C}: 0.19,0.45,0.25$, $0.82,0.27$. 
If such fluctuations occurred in the sime laboratory, the results from different laboratories might be expected to vary still more. Accordingly, the deathrate constant was generally considered unreliable, and the concentration exponent never became popular. Standardization was continued by the phenol coefficient. The method was "improved" by detailed specifications as to medium, time, temperature, bacterial species and strain to be used, and as to the size of the loop employed for its transfers.

These specifications limit the usefulness of the phenol coefficient because the values thus obtained are correct only in this narrowly limited set of specified conditions and may be of little use with changed conditions. But the limitations made the phenol coefficients more uniform.

The present Standard Method in the United States is that outlined by the Federal Drug Administration, usually referred to as the F.D.A. method. In order to compute the phenol coefficient of an unknown disinfectant, the lowest concentration of the latter is determined which will kill the test culture in 10, but not in 5 minutes. At the same time, the lowest phenol concentration is ascertained which kills the bacteria in 10 , but not in 5 minutes. The ratio of these two concentrations is the phenol coefficient, which tells how much stronger the unknown disinfectant is than phenol.

In the above example, Table 19, the concentrations which kill in 10 minutes are $1.04 \%$ for phenol and 0.006 for $\mathrm{HgCl}_{2}$. The phenol coefficient is therefore $1.04 / 0.006=$ 173. The other two values of Table 19, which show the effect of concentration, are disregarded in the definition of the phenol coefficient which is considered correct only for 10-minute exposures, and not for 2.5 or 30 minutes.

While the very important role of concentration is completely neglected by the F.D.A. method, attention is given to the variability of the test culture. The "Hopkins 
strain" of the typhoid bacterium is the only strain used for standard experiments, but even with this strain death may occasionally occur more rapidly or more slowly than usual. In order to exclude such fluctuations, the F.D.A. method considers phenol coefficients as being correctly established only when the control cultures are killed by phenol within the following ranges of time and concentration:

Dilution Concentration $5 \mathrm{~min} .10 \mathrm{~min} .15 \mathrm{~min}$.

$\begin{array}{lllll}1: 90 & 1.11 \% & + & 0 & 0 \\ 1: 100 & 1.00 \% & + & + & +\end{array}$

and

$\begin{array}{llccc}1: 90 & 1.11 \% & 0 & 0 & 0 \\ 1: 100 & 1.00 \% & + & + & 0\end{array}$

This means that the culture may be so resistant that it can tolerate $1.00 \%$ phenol for 15 minutes, but must be killed by $1.11 \%$ in 10 minutes, or it may be so sensitive that it is killed by $1.11 \%$ in 5 minutes, but it must survive for at least 10 minutes at $1.00 \%$.

It may seem strange that the death rates fluctuate so greatly while phenol coefficients are uniform enough to be miversally accepted. However, the fact is that we are really fooling ourselves about the accuracy of the phenol coefficient. Both methods are based on the same principle, and their accuracy should therefore be approximately the same. The apparently greater accuracy of the phenol coefficients is due to the enforcenent of rery specified conditions, and to the discarding of all those results where the controls did not remain within the narrow limits permitted by the rules of the method. If such severe restrictions had been applied to the determination of the concentration exponent, its accuracy would have been equal to that of the phenol coefficient.

But even the range allowed by the F.D.A. method permits a great fluctuation of results; an experinent is 
considered equally correct whether the bacteria are killed by $1.11 \%$ phenol in 14 minutes or by $1.0 \%$ in 11 minutes. This means a fluctuation in the deathrate constant the range of which can be calculated. In our standard equation

$$
\mathrm{Ktc}^{\mathrm{n}}=\log \frac{\text { initial number }}{\text { survivors }}
$$

the ratio of the initial number of bacteria to that of the survivors is constant for any set of experiments and therefore, for any combination of time and concentration. We have, then,

$$
\mathrm{K}_{1} \mathrm{t}_{1} \mathrm{c}_{1}{ }^{\mathrm{n}}=\mathrm{K}_{2} \mathrm{t}_{2} \mathrm{c}_{2}{ }^{\mathrm{n}} \text {. }
$$

Substituting the above limiting values of the F.D.A. method for $t$ and $c$, and taking 6 as the concentration exponent of phenol, we find

$$
\mathrm{K}_{1} \times 11 \times 1.0^{6}=\mathrm{K}_{2} \times 14 \times 1.11^{6}
$$

and,

$$
\mathrm{K}_{1}=2.4 \mathrm{~K}_{2} \text {. }
$$

The deathrate constant in one experiment may be 2.4 times as high as in the other.

We must further consider that the killing time by the unknown disinfectant nust be more than 5 and less than 10 minutes. Sterility may be reached in one case in 6 minutes, in another case in 9 mimutes. This increases the range of the deathrate by $9 / 6$ or 1.5 , so that in two standard experiments, one may have been carried out with a deathrate constant which was $1.5 \times 2.4=3.6$ times as large as in the other experiment. Any experiment having a greater error, i.c., greater than $360 \%$, is discarded as not being carried ont under standard conditions. This is the error which the specified conditions permit and to which must be added the personal error of the experimenter.

That phenol coefficients are by no means precisely de. fined values nay be seen from Table 20 , which shows that two different anthors obtained for mereurochrome phenol 
TABLE 20

Phenol coefficients

(The data of this table are gathered from McCullough's book 1936, except the first five figures in column I for staph. aureus which are from Thomas, 1932, and those of column II which are from Birkhaug, 1933.)

\begin{tabular}{|c|c|c|c|}
\hline \multirow{3}{*}{$\begin{array}{l}\text { Disinfectant } \\
\text { Hydrogen ions }\end{array}$} & \multirow{3}{*}{$\begin{array}{c}\begin{array}{c}\text { Bacterium } \\
\text { typhosum }\end{array} \\
1,400\end{array}$} & \multicolumn{2}{|c|}{$\begin{array}{c}\text { Staphylococcus } \\
\text { aureus }\end{array}$} \\
\hline & & I & II \\
\hline & & .... & \\
\hline Hydroxyl ions & 23,000 & & \\
\hline Bichloride of mercury & 775 & 166 & 189 \\
\hline Merthiolate & 600 & 62.5 & 1412 \\
\hline Metaphen & 1,792 & 2250 & 1647 \\
\hline Mercurochrome & 133 & 267 & 90 \\
\hline Ethyl mercury chloride & 88.3 & 233 & \\
\hline Phenyl mercuric nitrate & $\ldots$. & $\ldots$. & 2259 \\
\hline Silver nitrate & 173 & $\ldots$ & \\
\hline Potassium permanganate & $200^{*}$ & $\cdots$ & \\
\hline Hydrogen peroxide & 5.6 & 4.8 & \\
\hline Chlorine & $218-233$ & 220 & \\
\hline Iodine & $170-235$ & $170-235$ & \\
\hline Methyl alcohol & 0.026 & 0.030 & \\
\hline Ethyl alcohol & 0.040 & 0.039 & \\
\hline n-Propyl alcohol & 0.102 & 0.082 & \\
\hline n-Butyl alcohol & 0.273 & 0.22 & \\
\hline n-Amyl alcohol & 0.78 & 0.63 & \\
\hline n-Hexyl alcohol & 2.3 & .... & \\
\hline n-Heptyl alcohol & 6.8 & $\ldots$. & \\
\hline n-Octyl alcohol & 21.0 & $\cdots$ & \\
\hline Phenol & 1.0 & 1 & \\
\hline o-Cresol & 2.2 & 2.3 & \\
\hline$p$-Cresol & 2.4 & .... & \\
\hline$p$-Xylenol & 5.5 & -... & \\
\hline Thymol & 28.5 & 23 & \\
\hline Carvacrol & 27.5 & & \\
\hline o-Phenyl phenol & 50 & 57 & \\
\hline$p$-Benzyl phenol & 62 & - & \\
\hline Hexyl resorcinol & 140 & 72 & \\
\hline Formaldehyde & 1.05 & 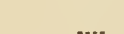 & \\
\hline Acetaldehyde & 0.09 & $\cdots$. & \\
\hline Propionic aldehyde & 0.15 & $\ldots .$. & \\
\hline Butyric aldehyde & 0.32 & $\ldots .$. & \\
\hline Methyl methyl ketone & 0.04 & 0.036 & \\
\hline Methyl ethyl ketone & 0.102 & 0.080 & \\
\hline Methyl n-propyl ketone & 0.275 & .... & \\
\hline Methyl $n$-butyl ketone & 0.78 & $\ldots$. & \\
\hline Methyl n-amyl ketone & 2.3 & $\ldots$. & \\
\hline
\end{tabular}

*) With washed cells 
TABLE 20 (Continued)

Phenol coefficients

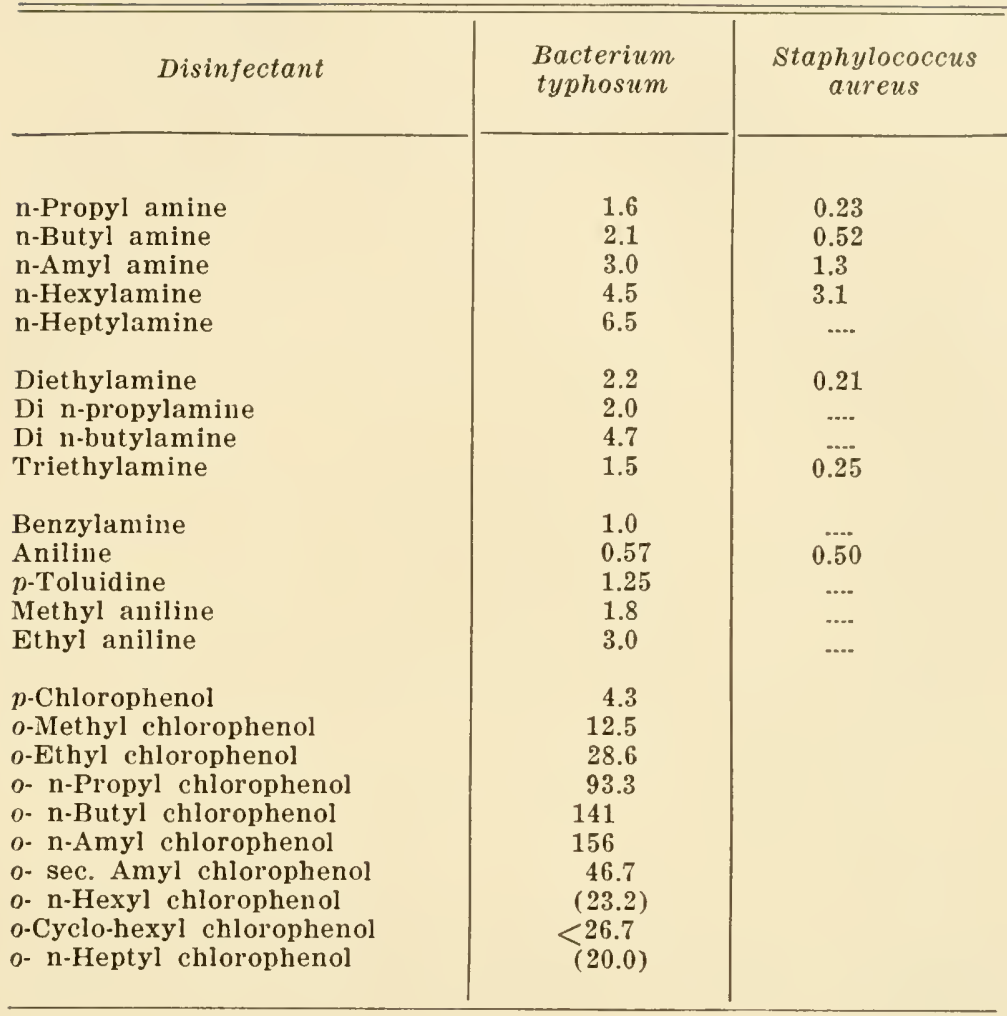

coefficients of 90 and 267 respectively, one value being 3 times as large as the other. The phenol coefficient of chlorine was found by McCulloch (1936) to be 139, by Rideal 218 and by Zoller 223, all data being obtained with Bacterium typhosum.

The above-mentioned deathrate constants observed by Chick for the effect of phenol upon paratyphoid bacteria show a deviation of the extremes greater than $360 \%$. Of the 5 constants found on different days, 4 differ by less than $360 \%$ but the highest value is 4.3 times as large as the lowest while the F.D.A. method considers 3.6 times the permissible limit. Obviously, the culture was unus. 
ually sensitive on this particular day. The F.D.A. method discards such data as abnormal, and they do not appear in the reports. But Chick's mexpurgated data are used as proof that deathrate constants fluctuate too much to be of value. The establishment of limits of sensitivity for the phenol coefficient proves clearly that the same fluctuations occur there, but they are never mentioned in publications. As has been said before, if we consider the phenol coefficients more accurate than the deathrate constants, we are merely fooling ourselves. They appear more accurate only because the larger deviations are not published.

As a result of this anathema on the deathrate constant, few data can be found in the literature. Watkins and Winslow (1932) give four sets of data on the death of Bacterium coli by alkali. Each set concerns a different cell age and consists of $t$ single experiments. The highest and lowest values of $K$ in each set are:

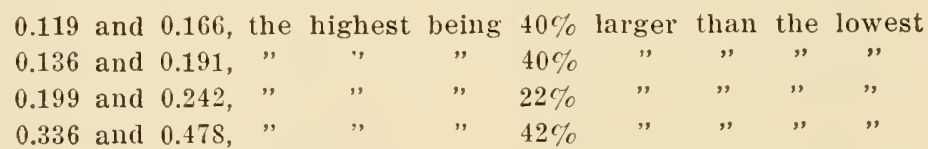

This proves that with our present knowledge of the influence of $\mathrm{pH}$, organic matter, cell concentration, culture medium and age of the cells, which was not available in 1911 when Phelps proposed the standardization of disinfectants by death rates, the deathrate constants can be measured as accurately as the phenol coefficients. They would have the advantage of telling the efficiency of a disinfectant directly, and not merely from comparison with another disinfectant such as phenol.

Finally the attention of experimenter's should be called to a common source of eror in any method which involves the determination of a death time. It is not always realized that a culture showing no growth when transfer'red to broth may not be sterile. "No Growth" means that no living cell remained in the one loopful 
transferred, but the latter amounts to only 0.01 cc., so that "no growth" indicates that the culture contained less than 100 surviving cells per cc. It may have contained 50. If the arerage inoculum for the determination of the phenol coefficient, 100 million cells, is reduced to 50 living cells per ce. in 10 minutes, it requires nearly 5 minutes longer to make the entire culture sterile, i.e., to reduce the survivors to 0.1 per test tube of $5 \mathrm{cc}$.

Other Methods of Standardization. Another method suggested by Bronfenbrenner, Hershey and Doubly (1938) for the standardization of disinfectants should be mentioned here. These authors, working on the theory that death is due to inactivation of enzymes, measured the effect of disinfectants upon the oxygen uptake of Bacterium coli, and of liver cells (see Table 21). They compared the concentrations causing an equal decrease in oxygen consumption, and thus obtained a toxicity index comparable to the therapentic index. In 1939, Ely tested this method on several disinfectants, but his results were not very encouraging.

\section{TABLE 21}

Manometric evaluation of disinfectants by the determination of the decrease in oxygen uptake. (From Bronfenbrenner, Hershey and Doubly, 1938.)

\begin{tabular}{|c|c|c|c|}
\hline \multirow{2}{*}{ Disinfectant } & \multicolumn{2}{|c|}{$\begin{array}{c}\text { Concentration }(\%) \text { which } \\
\text { reduces oxygen uptake } \\
\text { to one-half }\end{array}$} & \multirow{2}{*}{$\begin{array}{l}\text { Toxicity } \\
\text { index }\end{array}$} \\
\hline & Liver cells & Bact. coli & \\
\hline $\begin{array}{l}\text { Phenol } \\
\text { Tincture of iodine } \\
\text { Mercuric chloride }\end{array}$ & $\begin{array}{l}0.23 \\
0.0165 \\
0.0040\end{array}$ & $\begin{array}{l}0.26 \\
0.0425 \\
0.00085\end{array}$ & $\begin{array}{l}1.1 \\
2.6 \\
0.21\end{array}$ \\
\hline
\end{tabular}

PROPOSAL OF A NEW METHOD FOR TESTING DISINFECTANTS

It is possible by relatively slight changes in the technique to measure the actual efficiency of a disinfectant at 
different concentrations instead of its relative value in comparison with phenol, and also to measure the effect of organic matter. Such a method requires more time, but the far more useful result makes this expenditure of time worth while. The method consists, in principle, in determining the time in which the standard bacterial suspension will be sterilized by various dilutions of the disinfectant.

In the method of the phenol coeffieient, the effect of organic matter is not sufficiently eliminated, since $10 \%$ of the suspension medium is broth. In the present method, the bacteria are grown in broth in a centrifuge tube which is centrifuged when the culture is $2+$ hours old, and the cells are then re-suspended in sterile water or in a mineral solution known to prolong their life without providing food. (Such solutions have been worked out by Zeug, 1920.) The cell concentration is the same as it was in the culture.

Cultivation of the test organism and all other details of the procedure are the same as for the determination of the phenol cocfficient. The disinfeetant is made up in various concentrations (the pharmacologists will probably continue to prefer" "dilutions" to concentrations) and the death time is determined as usual by transfer with a standard loop into broth tubes. The culture may also be tested against phenol so as to cheek unusual fluctuations of the test organism.

The results can be arranged in the form of a chart as in Table 22 or in the form of a graph in which the death times are plotted against concentrations on a double logarithmic seale, as in Figure 23. The tabular form is handy for the recording of data for further reference, but the graph is far more instructive. Since the death time is not known precisely, but lies within a certain range, the entire range should be plotted on the graph as a line, and not merely its arerage (see Figures 17 and $2: 3)$. Thus instead of drawing the disinfection curve through points, 
we draw them through lines which represent ranges of death times.

The curve obtained must be a straight line as explained on p. 72. Different slopes indicate different concentration exponents. Figure 23 shows a number of such curves for common disinfectants. Phenol and permanganate furnish slopes quite different from those of the other disinfectants, thus indicating unusual concentration exponents.

Rectilinear interpolation and extrapolation give the death times for any concentration, or the concentrations necessary to kill the bacteria at any exposure time.

These curves represent the effect of the disinfectant upon bacteria in the absence of organic matter. The effect of organic matter can be measured quantitatively by a parallel set of death time determinations, the disinfectant being dissolved in water containing 10\% skimmed milk. The results are plotted in the same way as those with water, and again, straight lines are obtained.

The effect of organic matter is expressed by the "percentage delay." This is calculated from the two death times at the same concentration (which may eventually be obtained by extrapolation). Death time in milk will be longer than death time in water or salt solution, and the percentage of increase in time tells to what extent organic matter interferes; e.g., for hydrogen peroxide the delay in skimmed milk is $30 \%$, for formaldehyde $20-27 \%$, for $\mathrm{HgCl}_{2}$ many thousand per cent.

The phenol coefficient can be obtained directly from the graph by dividing the phenol concentration which kills "between 5 and 10 minutes" by the corresponding concentration of the disinfectant under test. In most cases, the coefficient measured at 5 minutes will be larger than that measured at 10 minutes because, phenol having the highest concentration exponent known, the slope of the phenol disinfection curve is more nearly vertical than 
TABLE 22

Death times (in minutes) of Bacterium coli suspended in water and in milk

\begin{tabular}{|c|c|c|c|c|c|c|c|}
\hline $\begin{array}{c}\text { Concentr. } \\
(\%) \text { : }\end{array}$ & $\begin{array}{lll}2 & 1.5 & 1.0\end{array}$ & $0.8 \quad .06$ & $\begin{array}{lll}0.4 & 0.2 & 0.1\end{array}$ & $0.08 \quad 0.06$ & 0.04 & 0.02 & 0.01 \\
\hline Dilution: 1: & $\begin{array}{lll}50 & 67 & 100\end{array}$ & 125167 & $250 \quad 500 \quad 1000$ & $1250 \quad 1670$ & 2500 & 5000 & 10,000 \\
\hline
\end{tabular}

Phenol

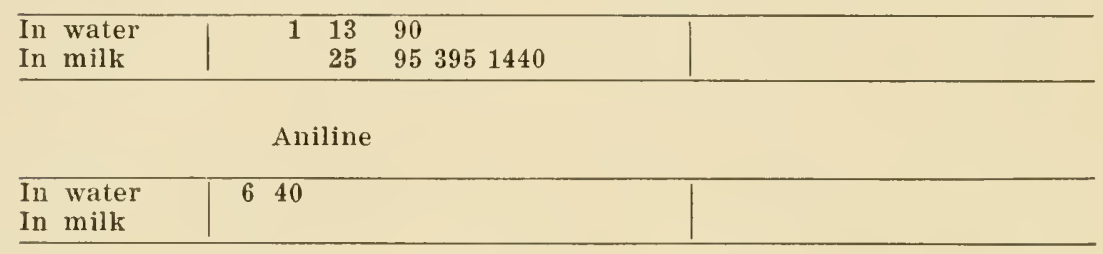

Formaldehyde

\begin{tabular}{l|rrrr|l}
\hline In water & $\mathbf{5}$ & $\mathbf{9}$ & $\mathbf{1 2}$ & $\mathbf{1 8}$ & \\
In milk & 7 & 12 & 17 & 30 & \\
\hline
\end{tabular}

Hydrogen Peroxide

\begin{tabular}{l|rrrrrr|r}
\hline In water & 2 & 3 & 5 & 8 & 24 & 65 & \\
In milk & 3.5 & 5 & 7.5 & 13 & 35 & 90 & \\
\hline
\end{tabular}

\section{Mercurochrome}

\begin{tabular}{l|rrr|rrrr}
\hline In water & 8 & 20 & 50 & 65 & 90 & 5 & 15 \\
In milk & 8 & & \\
\hline
\end{tabular}

Potassium Permanganate

\begin{tabular}{l|l|l}
\hline In water & & 0.8 \\
In milk & & 0.8 \\
\hline
\end{tabular}

\begin{tabular}{l|l|l}
\hline In water & & \\
In milk & \\
\hline
\end{tabular}

\begin{tabular}{l|l|l}
\hline In water & & \\
In milk & & \\
\hline
\end{tabular}


TABLE 22 (Continued)

\begin{tabular}{|rrrrr|rrrrrr}
\hline \hline 0.008 & 0.006 & 0.004 & 0.002 & 0.001 & $S$ ppm. 6 ppm. 4 ppm. 2 ppm. 1 ppm. \\
12,500 & 16,700 & 25,000 & 50,000 & 100,000 & 125,000 & 167,000 & 250,000 & 500,000 & $1,000,000$ \\
\hline
\end{tabular}
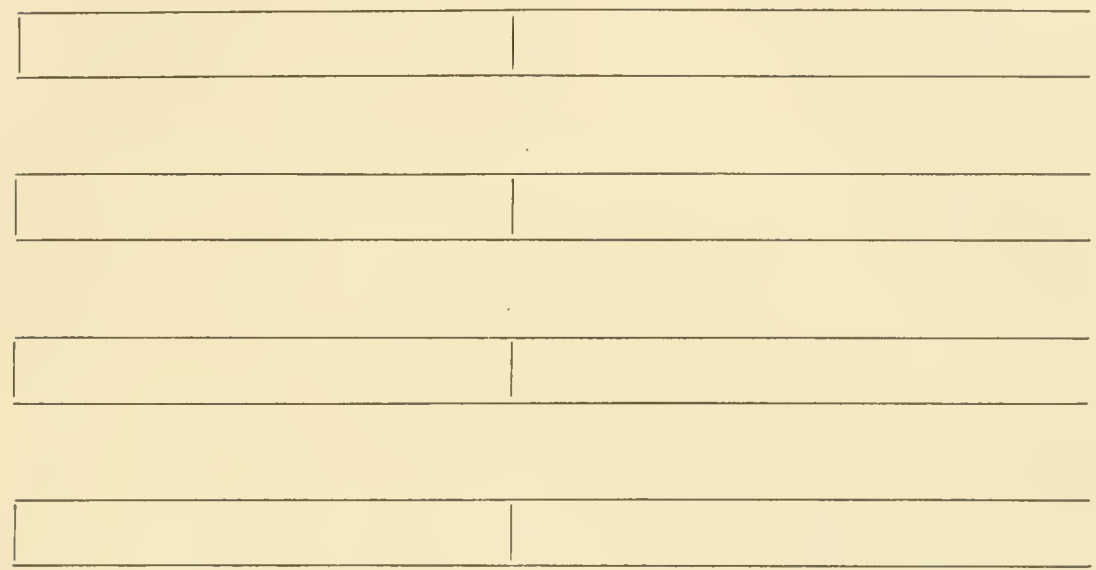

Mercurochrome

\begin{tabular}{|lll|l|}
\hline 20 & 30 & 45 & \\
\hline
\end{tabular}

Potassium permanganate

\begin{tabular}{|lll|l}
\hline 2.4 & 9 & 45 & \\
\hline
\end{tabular}

Mercuric Chloride

\begin{tabular}{rrr|rrrrr}
\hline 6 & 15 & 1.2 & 1.8 & 3 & 6 & 18 & 65 \\
\hline
\end{tabular}

Silver Nitrate

\begin{tabular}{|l|lllll}
\hline & 3 & 7 & 25 & 90 \\
\hline
\end{tabular}




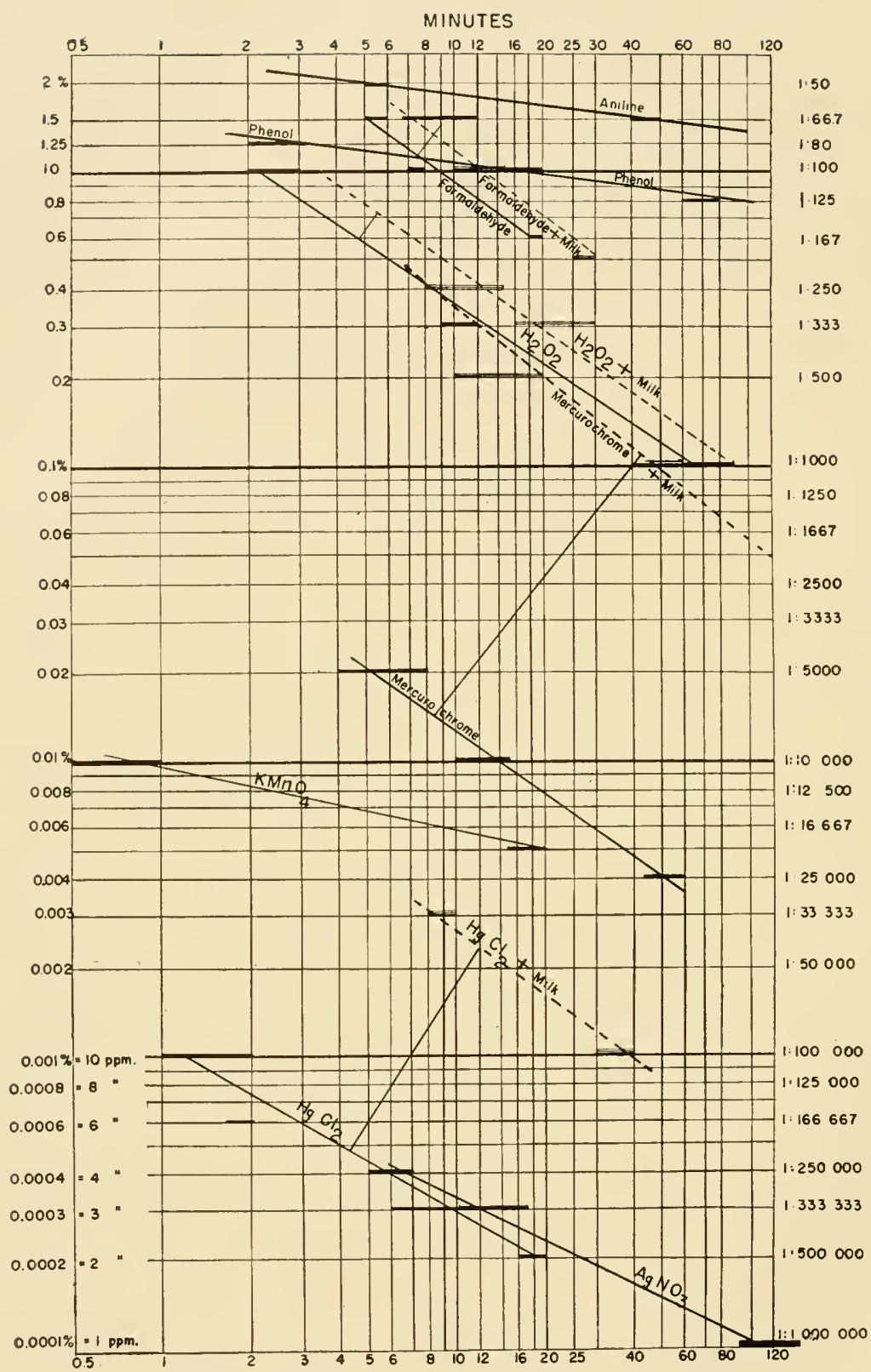

Fig. 23. Relation between death time of Pacterium coì and concen. tration of disinfectants. The heavy horizontal bars (representing ranges of death time) and the solid lines which join them refer to washed bacteria, the multiple horizontal bars and the broken lines which join them refer to suspensions containing $10 \%$ skim milk. Abscissa: death time, on logarithmic scale; ordinate: concentration of disinfectant, on logarithmic scale. 
that of other disinfectants. (As was said above, this accounts for the great discrepancies in the values of the phenol coefficient deternined by different worker's for a given disinfectant.)

The disinfection curves for different temperatures will be parallel lines equidistant for equal temperature changes as long as the temperature coefficient is constant.

The efficiency of a few disinfectants, such as chlorine and mercurochrome, varies greatly with the acidity of the test solution. This effect can be measured by drawing separate disinfection curves for each $\mathrm{pH}$ that is of interest. The lines will be parallel, as a rule, and their distance measures the effect of $\mathrm{pH}$ on the disinfecting power.

Justification of the New Features of $t$ he $M e t h o d$. The advisability of measuring the death times for several different concentrations is quite erident from the different slopes of the disinfection curves of the various disinfectants. These different slopes indicate how differently the efficiency of the disinfectants is affected by changes in concentration.

For the determination of the effect of organic matter, skimmed milk seems ideal because its composition is reliably uniform all over the world, and because it contains dissolved proteins and carbohydrates as well as finely suspended organic matter (casein).

The resuspension of centrifuged bacteria in water is necessary to remove the broth which contains sufficient organic matter to interfere with such strong disinfectants as $\mathrm{HgCl}_{2}$ or iodine. In the F.D.A. method for the phenol coefficient, the 1/2 ec. of culture used brings 1500 ppm. of organic matter into the disinfectant. One centrifugation reduces it to about 25 ppm. dissolved organic matter besides 20 ppm. of bacterial solids. A second washing (which is advisable with such disinfeetants as chlorine and iodine) reduces it to about $0.5 \mathrm{ppm}$. 
The use of pathogenic species for disinfection studies offers no advantages. Saprophytes can be handled more easily. The strain of Bacterium coli used by us has a phenol coefficient almost identical with that of the Hopkins strain of Bact. typhosum.

\section{DETAILS OF THE PROCEDTRE}

It is advisable to make a strong solution of the disinfectant some time before the test, to be certain of a sterile start. Dilutions are made, as was said above, either with water, or with a mineral solution which keeps bacteria viable for a long time. For Bacterium coli we used a solution containing $0.05 \% \mathrm{NaCl}$, $0.02 \% \mathrm{KCl}, 0.05 \% \mathrm{CaCl}_{2}$ and $0.05 \% \mathrm{IgCl}_{2}$, although Brooks and Winslow (1927) have shown that this species can remain alive in distilled water for a long time. All dilutions of disinfectants, and all salt solutions must be prepared with glassdistilled water. Small Erlenmeyers containing about 50 ce. of this salt solution, and others containing skimmed milk diluted $1: 10$ are sterilized and kept in stock.

The test culture to be used is a 24-hour culture grown in standard nutrient broth at $37^{\circ}$. It is centrifuged, and the bacteria are re-suspended in the sterile salt solution to the volume of the original culture.

The actual exposure of the bacteria to the disinfectant is done in $18 \mathrm{~mm}$. test tubes which permit thorough mixing. The final volume is always $5 \mathrm{ce}$. If the concentrations $0.2 \%, 0.1 \%$ and $0.05 \%$ are desired, they can be made from a $0.5 \%$ solution of the disinfectant according to the following chart:

$0.2 \%=2$ ce. of $0.5 \%+2.5$ cc. salt sol'n +0.5 ce. bact. susp'n $0.1 \%=1$ cc. of $0.5 \%+3.5$ cc. salt sol'n +0.5 cc. bact. susp'u $0.05 \%=0.5 \mathrm{cc}$. of $0.5 \%+4.0 \mathrm{cc}$. salt sol'n +0.5 cc. bact. susp'n

The disinfectant and salt solution (or milk) are mixed first and then the tube is sloken and placed into a water bath at $20^{\circ}$. When it has reached a constant temperature, the bacterial suspension is added. The probable death times for each concentration are estimated, and arranged into a time sched. ule of the following type:

$\begin{array}{rrrrrrr}0.2 \%: & 1 / 2, & 1, & 2, & 3, & 5 & \text { minutes; } \\ 0.1 \%: & 2, & 4, & \text { S, } & 15, & 30 & \text { minutes; } \\ 0.05 \% & 15, & 30, & 45, & 60, & 90 & \text { minutes; }\end{array}$


or preferably plotted in a graph which tells what is to be done every minute, $e . g$.

$\begin{array}{llllllllllllllll}0 & 1 & 2 & 3 & 4 & 5 & 6 & 7 & 8 & 9 & 10 & 11 & 12 & 13 & 14 & 15\end{array}$

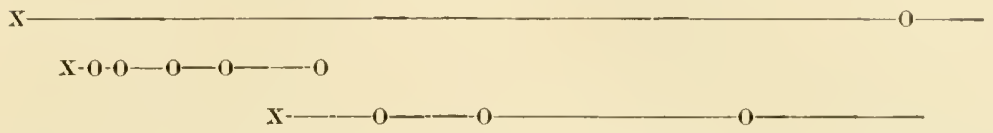

where $\mathrm{x}$ indicates inoculation and o transfer of a loopful to new broth.

Thus only the disinfectant concentration of $0.0 .5 \%$ is inoculated at the start, the inoculation of the $0.2 \%$ concentration comes one minute later, and that of the $0.1 \%$ solution not until 5 minutes later. It is usually possible to work ont a schedule by which a large number of different determinations can be fitted together so as to aroid long waiting between transfers.

With an entirely unknown substance, a proliminary test will save time. A spacing of the concentrations in decimal multiples such as $1 \%, 0.1 \%$ and $0.01 \%$, or 400 ppm., 40 ppm., 4 ppm., and a spacing of the times in multiples of their logarithms are advisable. I good range of preliminary testing times is that which includes $1,3,10$, and 80 minutes, since their logarithms are about 0.5 apart $(0 ; 0.48 ; 1.0 ; 1.4 S)$. If the results of such a preliminary test are entered into a double logarithmic graph, the slope of the resulting curve tells at once the more desirable combinations of times and concentrations to be used. If, for example, one concentration is strong enough to kill all bacteria in 1 minute while one-tenth of that concentration does not kill in 30 minutes, this indicates a high concentration exponent, which is a warning not to space the concentrations too widels in the final test; in this case, a range of $1 \%, 1.5 \%$ and $2 \%$ may suffice. Phenol, which at $2 \%$ kills in less than $1 / 2$ minnte aud at $0.2 \%$ requires more than 10 hours, and $\mathrm{KMnO}_{4}$, which at 100 pym. kills in less than 1 minute and at 10 ppm. requires 10-20 homrs, are typical examples of disinfectants with rely high exponents. A glance at Figure 23 will lielp in deciding the most appropriate range of dilutions to be used.

In order to prove that the test culture lias a normal sensitivity, the author lıas always determined simultaneously its death time in a $1 \%$ phenol solution. 


\section{A N T I S E P T I C S}

Under this general term are assembled those compounds which are used primarily to prevent multiplication of bacteria but are not intended to produce complete sterility. While disinfectants, as was already said above, dissupt the reproduction mechanism irreversibly and irreparably, antiseptics prevent multiplication only as long as they are present; their removal permits the various cell mechanisms to resume their normal function. It was also pointed out that antiseptics often kill some or even many of the cells, but death then occurs at such a low rate that it would take weeks or eren months to achieve complete sterility. In some cases, this slow death occurs only at the start and is followed later by a period of no further dying, and sometimes even by multiplication.

The practical efficiency of antiseptics can be measured only in one way, namely by determining the lowest concentration which prevents multiplication. The inhibiting dose may vary not only with the medium and the temperature, as would be expected from analogy with disinfectants, but also with the number of cells present. For example, the multiplication of Bacterium coli in broth is completely inhibited by $1: 100,000$ crystal violet if only 100 cells per ce. are present; but with 10,000 cells per ce., multiplication sets in after a temporary delay. That delay in multiplication does not oecur with disinfectants; with them, when larger inocula require a longer exposure time ${ }^{1}$, it is to cause death, not to retard multiplication.

1. See p. 54 . 
An outstanding feature of the antiseptic reaction is its immediate effect. As soon as the cells are in contact with the antiseptic, they cease to multiply. The reaction may be compared to pulling the switch of an electric motor. The motor stops and continues to be motionless as long as the current is interrupted, although the motor is intact. It runs again when the switch is thrown in, just as the cells begin to multiply again when the antiseptic is removed.

This immeasurably rapid reaction of the antiseptic is different from the slow death-producing reaction characteristic of a disinfectant. To contimne our simile of the electric motor, the disinfectant action is comparable to a gradual deterioration of the motor, as through rust $\mathrm{or}^{\circ}$ corrosion by acid vapors. This deterioration also interferes with the rumning of the motor, and it is irreversible, but deterioration is slower than pulling a switch.

The slow reaction of the disinfectant requires a considerably higher concentration of the toxic substance than the instantancous but reversible reaction produced by the antiseptic, and, in fact, all disinfectants act also as antiseptics at low concentrations. They inhibit multiplication at once, but produce their irreversible effect only gradually. They first, so to speak, pull the switch of the motor, and then cause it to deteriorate. The antiseptic ouly pulls the switch. If there is also deterioration, it is very slow.

The essential differences between the antiseptic and the disinfectant reactions are thus that one is slow and gradually progressing, but requires a fairly high concentration of the toxic agent, and produces an irreversible effect while the other is practically instantaneous and requires a relatively dilute solution, but its effect is reversible. These reactions probably affect different cell constituents, or at least different parts of the molecule of the same constituent. A good example of the two re- 
actions produced by the same toxic agent has already been given in the experiments by Gegenbaner with mercuric chloride. The inhibition of growth of staphylococci could be reversed during the first hour of exposure by repeated washing, but after longer exposure, even an antidote would not restore the ability to multiply. Another example in which antisepsis and disinfection effects have been measured separately will be found later in the discussion of crystal violet.

Antiseptics cannot be studied in the same way as disinfectants because with them there is no measurable rate of reaction, no deatlı rate and no death time. The instantaneous reaction is followed by a period of no further change in the status of antisepsis. Even if some or all cells slowly die, that does not affect the status of antisepsis, for the dead eells continue not to multiply, just as the living cells do not multiply. The exceptional ease of the sulfa drugs which permit a short period of apparently normal growth before the status of antisepsis becomes established will be treated in a separate chapter.

An antiseptic is eharacterized by the lowest concentration which will inhibit multiplication. Higher concentrations produce no effect different from that of the sufficient concentration. Since little can be concluded from the knowledge of only the inhibiting concentration, the effect of more dilute solutions is also studied. Such solutions are not truly antiseptic, but important conclusions ean be drawn from their effect on the rate of multiplication, the lengtl of the lag period, and the final crop. The rate of multiplication is usually retarded, the lag period is greatly prolonged by some antiseptics, but not changed at all by others, and the final crop usnally decreases as the antiseptic concentration increases. This latter effect is well illustrated by the following data on 
the influence of various concentrations of sulfanilamide on a culture of Bacterium coli in broth:

Concentrations

$$
\begin{aligned}
& 1.0 \% \\
& 0.75 \% \\
& 0.50 \% \\
& 0.25 \% \\
& 0.10 \%
\end{aligned}
$$

Final erop $<5,000,000$ cells per ce.

$$
110,000,000
$$$$
250,000,000
$$$$
900,000,000
$$

$1,000,000,000$

The culture with $1 \%$ sulfanilamide showed no visible turbidity, gave a slight indication of growth in the nephelometer, and the plate count definitely proved a slight multiplication in the course of 10 days, which did not progress further during another week of observation.

\section{TEMPERATURE AND ANTISEPSIS}

With disinfectants, an increase of temperature increases the rate of reaction between cells and the toxic compound, and thus increases the efficiency of the disinfectant. Since antiseptics react with immeasurable velocity, this rate camnot be influenced to a measurable degree by temperature. Howerer, the effect is reversible and must be considered as representing an equilibrium. Equilibria are affected by changes in temperature, and equilibria of instantaneous ionic reactions are as dependent upon temperature as those of slow organic reactions.

The equilibrium constants of exothermic and endothermic reactions are affected in opposite ways by a change of temperature. The precise nature of the reaction which interferes with multiplication when the antiseptic is added to a culture is not known. It may be endothermic with one antiseptic and exothermic with another. It is therefore impossible to predict in a general way the effect of temperature on all antiseptics. 
If the antiseptic reaction is endothermic, an increase in temperature shonld decrease the efficiency of the toxic compound. This is contrary to all experience in disinfection, but at least one such ease has been reported. Cameron (1930) observed that thermophilie sporeformers causing "flat sour's" in canned regetables required $10 \mathrm{ppm}$. of gentian violet at $55^{\circ} \mathrm{C}$ for complete inhibition, while at $37^{\circ}, 1 \mathrm{ppm}$. sufficed to inhibit growth.

As a rule, however, a higher temperature makes an antiseptic mole efficient, which suggests that the antiseptic reaction is generally exothermic. More antiseptic will then be needed at low temperatures than at high temperatmres to suppress microbial development. McCulloch $(1936$, p. 228) mentions that a certain glue was protected against molding by a phenol concentration which was quite sufficient in summer, but which did not prevent spoilage when the temperature dropped to abont $10 \mathrm{C}$.

As no rates can be measured in antisepsis, no temperature coefficients can be computed. The only possibility of expressing temperature relations is the recording of the lowest inhibiting concentration for each temperature.

But here, a considerable range of errors may be expected. Limiting values camnot be very precise when the approach to the limit is asymptotic as in antisepsis. For instance, Crness and Richert (1929) report that at pH 3.0, Saccharomyces cllipsoideus was delayed by $0.02 \%$ sodium benzoate, but began to grow after 12 days; $0.06 \%$ benzoate inhibited growth completely. The minimal inhibiting dose lies somewhere between these two values. When the limiting concentrations at two different temperatures are determined, and when each value is subject to a considerable range of error, the ratio of these two concentrations is no sound basis for an attempt at explaining temperature effects. 


\section{SELECTIVE ACTION OF ANTISEPTICS}

At the begimning of the discussion of chemical disinfection, it was pointed ont that the strong disinfectants kill different species of bacteria at nearly the same rate, while dyes, benzoic and salicylic acid, and a number of therapentic agents show marked differences in their effects upon different groups of bacteria. Most of the selective compounds must be consilered as antiseptics rather than as disinfectants. Selectivity indicates that the cell mechanism upon which these substances act differs in those species which show different resistance.

The most commonly claimed instance of selectivity is that between Gram-positive and Gram-negative bacteria. Such correlation between staining property and vital function would be a rery great help to the biochemist. However, a closer analysis shows that many such claims are generalizations from tests with only very few species, and are by no means based upon a representative selection of Gram-positive and Gram-negative genera. If the tests are made only with Staphylococcus aureus and Bucterium typhosum, the two officially designated test species for disinfectants, no conclusion can be derived for other Gram-positive or Gram-negative organisms. If Hartmann (1936) had not included two bacilli in his study of the action of sodium azide (Table 23 ) he might have generalized and concluded that Gram-positive bacteria are more resistant than Gram-negative. The results obtained with the two bacilli proved conclusively that there was no eorrelation between Gram staining and azide sensitivity. We shall, however, present here the eridence from the literature for and against the correlation.

Diernhofer (1936), in an attempt to find a medium in which the mastitis streptococeus would outgrow the co- 
lon species, investigated the antiseptic action of many different compounds. Since this work illustrates the present problem, we give here (Table 24) the entire list of compounds he studied. It must be remembered, however, that Diernhofer's work refer's only to streptococci versus colon-proteus types, and makes no general claim for differentiation between Gram-positive and Gramnegative bacteria.

The best-known of the anti-bacterial substances produced by microorganisms, gramicidine, is so named because it is supposed to kill only Gram-positive bacteria. Dubos and Hotchkiss (1941) summarize as follows its selective action (and that of the allied substance, tyrocidine): "Pneumococci, streptococci, staphylococci, diphtheria and diphtheroid bacilli, aerobic and anaerobic sporulating Gram-positive bacilli, have all been found

TABLE 23

Sensitivity of various organisms to sodium azide. (From Hart$\operatorname{mann}, 1936$.)

\begin{tabular}{|c|c|c|c|}
\hline $\begin{array}{c}\text { Number } \\
\text { of } \\
\text { strains } \\
\text { tested }\end{array}$ & Species & $\begin{array}{l}\text { Retarding } \\
\text { concentration } \\
\quad(\text { ppm.) }\end{array}$ & $\begin{array}{l}\text { Inhibiting } \\
\text { concentration } \\
\text { (ppm.) }\end{array}$ \\
\hline 8 & Streptococcus agalacticae & 350 & $>500$ \\
\hline 3 & " epidemicus & $>500$ & $>500$ \\
\hline 3 & " dyagalacticae & $>500$ & $>500$ \\
\hline 3 & "uberis & 200 & 300 \\
\hline 3 & “pyogenes & $>500$ & $>500$ \\
\hline 1 & " lactis, sucrose-positive & 100 & 400 \\
\hline 1 & "lactis, sucrose-negative & $>500$ & $>500$ \\
\hline 1 & "lactis, sucrose-negative & 100 & 300 \\
\hline 1 & Micrococcus sp. from milk & 200 & $>500$ \\
\hline 1 & " " " saliva & $>500$ & $>500$ \\
\hline 2 & " " " $\begin{array}{l}\text { milk \& } \\
\text { manure }\end{array}$ & 400 & $>500$ \\
\hline 1 & Yeast from mastitis udder & 50 & 50 \\
\hline 1 & Bacillus subtilis (?) & 50 & 150 \\
\hline 1 & Bacillus mesentericus (?) & 50 & 150 \\
\hline 1 & Bacterium coli & 50 & 150 \\
\hline 1 & Bacterium paracoli & 100 & 150 \\
\hline 1 & Proteus & 50 & 150 \\
\hline 1 & Nicrococcus, Gram-negative & 100 & 150 \\
\hline
\end{tabular}


TABLE 24

Differences in growth inhibition of streptococci and colon bacteria by various antiseptics. (From Hartmann, 1936, and Diernhofer, 1933 and 1936.)

Group I: Antiseptics inhibiting streptococci definitely more than the colon group:

Sodium oleate, $0.3 \%$

Victoria blue, $0.001 \%$

Patent blue, $1.0 \%$

Congo red, $1.0 \%$

Crystal violet, $0.001 \%$

Nile blue, $0.01 \%$

Uranyl acetate, $0.3 \%$

Cusylol, $0.03 \%$

Sodium fluoride, $0.01 \%$

Also: methyl violet, flavine (including its derivatives: scutellarein, dimethyl scutellarein and fisetin), quinine, strychnine, methyl amine, alpha naphthyl amine, pyridium, sodium borate, thiosulfate, potassium cyanide, ammonium rhodanate, veronal.

Group II: Antiseptics inhibiting the two groups of organisms about equally:

Hexa methylene tetramine, $0.1 \%$

Phenol, $0.01 \%$

Sulfo salicylic acid, $0.1 \%$

Sodium hippurate, $3.0 \%$

Sodium nitroprusside, $0.5 \%$

Quercitrin, $1.0 \%$

Lead acetate, $0.05 \%$

Barium chloride, $0.3 \%$

Ammonium oxalate, $1.0 \%$.

Chromic acid, $0.05 \%$

Also: formaldehyde, rongolite, chlorophyll, saponin, tannin, chloral hydrate, potassium ferricyanide, picric acid, diphenyl amine, anaesthesin, m-nitrophenol, and gamma-dinitro phenol.

Group III: Antiseptics inhibiting the colon group definitely more than the streptococci:

p-Nitrophenol, $0.05 \%$

$a$-dinitro phenol, $0.1 \%$

Antipyrin, $1.0 \%$

Hydroxyl amine, $0.03 \%$

Hydrazine, $0.03 \%$

Theophyllin sodium salicylate, $1.0 \%$

Sodium azide, $0.02 \%$

Also: pyramidone.

to be susceptible to both gramicidine and tyrocidine. On the contrary, the following Gram-negative groups, Escherichia, Klebsiella, Shigella, Salmonella, Hemophilus, Neisseria, are resistant to gramicidine, but susceptible 
to tyrocidine." To the first list can be added a Grampositive yeast which was killed by a fairly large dose of gramicidine and to the second a Gram-negative sporeformer which was not affected by the drug.

These convincing results have been in general confirmed by those of Downs (1942). There were, however, two exceptions: the meningococcus, which was more sensitive to gramicidine than the staphylococcus, and a sensitive avirulent strain of Pasteurella tularensis. These exceptions limit the validity of the general conclusion stated above, and, if confirmed, would disprove the conception that susceptibility to gramicidine and the property of Gram staining are due to the same mechanism, or involve the same cell constituents.

For penicillin, the same selectivity is sometimes claimed, but the order of sensitivity as given by Abraham et al. (1941) disproves this contention. Complete inhibition is not accomplished by $1,000 \mathrm{ppm}$. penicillin with Vibrio cholerae, Salmonella paratyphi and typhymurium, Klebsiella pneumoniae, Escherichia coli, Mycobacterium tuberculosis, Pseudomonas aeruginosa and Brucella melitensis. A somewhat higher sensitivity is observed with Pasteurella pestis, Brucella abortus, Shigella dysenteriae; $250 \mathrm{ppm}$. inhibit Streptococcus viridans, Proteus vulgaris, and an anaerobic streptococcus; $100 \mathrm{ppm}$. suffice for Diplococcus pneumoniae, and Ebcrthella typhi, 50 ppm. for Salmonella enteritidis. Then comes quite a gap in the degree of sensitivity; the next group includes Corynebacterium diphtheriae, inhibited by $8 \mathrm{ppm}$, and Clostridium oedematiens by 3 ppm., while 1 ppm. inhibits Streptococcus pyogenes, Staphylococcus aureus, Bacillus anthracis and Actinomyces bovis. Still more sensitive are Clostridium Welchii, inhibited by $0.7 \mathrm{ppm}$., and Neisseria gonorrhoeae by $0.5 \mathrm{ppm}$.

Since, in this list, most of the first-named organisms are Gram-positive and most of the last-named are Gramnegative, there appears to be a parallelism between 
Gram staining and sensitivity to penicillin (and this has been quite useful as a guide to medical application). However, there are striking exceptions, such as equal sensitivity of Streptococcus viridans and Proteus, or the extreme sensitivity of the Gram-negative Neisseria gonorrhoeae. Typical exceptions, even if few, are enough to disprove the assumption that Gram staining and susceptibility to penicillin are fundamentally of the same origin.

Another frequently made claim is that the basic dyes inhibit Gram-positive bacteria far more than Gram-negative. Ingraham (1933) investigated 20 species and arranged them in the order of their sensitivity to gentian violet (measured by a quantitative index). In her list the most sensitive genera were the Gram-positive Bacillus, Streptococcus and Staphylococcus; but among the most tolerant organisms were two species of Clostridium, which are usually considered Gram-positive. However, since both species are Gram-positive only when young, and become Gram-negative with age, this observation can not be considered as an argument against the general claim (see, however, the Chapter on Dyes).

Cooper and Mason (1927) studied the differences in the two outstanding Gram-negative groups, Bacterium coli and Pseudomonas. They came to the conclusion that the Pseudomonas group was very sensitive to such agents as heat or alcohol which produce physico-chemical changes of the colloidal state or denaturation of the protoplasm, but rather resistant to substances which react chemically, while the colon group showed the opposite characters. They determined the lowest concentrations inhibiting multiplication for 48 hours. With most reagents Pseudomonas putida, the most sensitive species of that genus, was more easily inhibited than Bacterium coli; but the differences in sensitivity were slight except with quinol and pyrogallol, of which Bacterium coli could tolerate more than twice as much as Pseudomonas. With 
a few disinfectants, Pseudomonus could withstand stronger doses. It could resist 8 times as much hydrogen peroxide, 6 times as much acriflavine, 3 times as much quinine and silver nitrate, and twice as much picric acid as Bacterium coli. These differences are small compared with those found between Gram-positive and Gram-negative bacteria.

There is an extensive literature on the addition to culture media of antiseptics which are meant to do no harm to a certain desired species, but to suppress most or all other species. The use of dyes for this purpose is quite general. In water bacteriology, a soap, sodium ricinoleate, is used, and a great number of other media have been proposed to separate Bacterium coli from other related species. To give just one instance of the comprehensiveness of the literature on that subject, it may be noted that volume 19 of Milchwirtschaftliche Forschungen contains not less than seven papers on selective media for the isolation of either Streptococcus agalacticae (mastitidis) or Brucella abortus. It is, of course, beyond the scope of this review to discuss all the applications of the selective action of antiseptics to the isolation of certain species.

\section{DILUTED DISINFECTANTS AS ANTISEPTICS}

The mode of action of antiseptics can be studied best by beginning with the effect of diluted disinfectants. Their lethal effect at higher concentrations, that is, the irreversible inactivation of the mechanism of cell division, is fairly well understood, but, as was pointed out in the introduction, the reversible inhibition or retardation of multiplication very probably is an entirely different chemical reaction.

To analyze the mechanism of growth inhibition, as was also explained above, it is not sufficient to know the min- 
imal inhibiting dose of a compound, it is necessary also to study the complete multiplication curve as affected by sub-minimal doses, to measure the length of the lag period, the multiplication rate and the final "crop." No such complete data for any particular compound could be found in the literature. For the data of Table 25, the author is indebted to Miss Jean E. Conn, of the Agricultural Experiment Station, Geneva, N. Y. They are part of a comprehensive study to determine the effect of acidity on rarious antiseptics.

It should be pointed ont first that the two compounds which are mentioned in this table and which will be considered here, formaldehyde and phenol, were hardly affected by acidity. With formaldehyde there was no influence whatever; at all acidities included in the test,

TABLE 25

Multiplication of Saccharomyces ellipsoideus in presence of phenol and formaldehyde. (Unpublished data by Jean E. Conn.)

\begin{tabular}{|c|c|c|c|c|}
\hline \multirow{2}{*}{$\mathrm{pH}$} & \multicolumn{4}{|c|}{ Phenol } \\
\hline & $\begin{array}{l}\text { Conc. } \\
(\%)\end{array}$ & $\begin{array}{l}\text { Lag } \\
\text { (hrs.) }\end{array}$ & $\begin{array}{l}\text { Generation } \\
\text { time (hrs.) }\end{array}$ & $\begin{array}{l}\text { Final population } \\
\text { (millions/cc.) }\end{array}$ \\
\hline $\begin{array}{l}3.1 \\
" ، \\
\text { "، }\end{array}$ & $\begin{array}{l}0.00 \\
0.10 \\
0.12 \\
0.14\end{array}$ & $\begin{array}{l}2-3 \\
2-3 \\
2-3 \\
3-6\end{array}$ & $\begin{array}{l}1.20 \\
1.88 \\
3.18 \\
3.48\end{array}$ & $\begin{array}{l}60 \\
30 \\
30 \\
14\end{array}$ \\
\hline 5.3 & $\begin{array}{l}0.00 \\
0.10\end{array}$ & $\begin{array}{r}2-3 \\
60\end{array}$ & $\begin{array}{l}1.29 \\
6.4\end{array}$ & $\begin{array}{l}40 \\
17\end{array}$ \\
\hline \multirow{2}{*}{$\mathrm{pH}$} & \multicolumn{4}{|c|}{ Formaldehyde } \\
\hline & $\begin{array}{l}\text { Conc. } \\
(\%)\end{array}$ & $\begin{array}{l}\text { Lag } \\
\text { (hrs.) }\end{array}$ & $\begin{array}{l}\text { Generation } \\
\text { time (hrs.) }\end{array}$ & $\begin{array}{l}\text { Final population } \\
\text { (millions/cc.) }\end{array}$ \\
\hline $\begin{array}{l}3.1 \\
، \\
“\end{array}$ & $\begin{array}{l}0.000 \\
0.004 \\
0.006\end{array}$ & $\begin{array}{r}2-3 \\
12 \\
60\end{array}$ & $\begin{array}{l}1.20 \\
2.58 \\
3.38\end{array}$ & $\begin{array}{c}60 \\
40 \\
30\end{array}$ \\
\hline 5.3 & $\begin{array}{l}0.000 \\
0.004 \\
0.006\end{array}$ & $\begin{array}{c}2-3 \\
15-18 \\
50-55\end{array}$ & $\begin{array}{l}1.29 \\
3.15 \\
3.66\end{array}$ & $\begin{array}{l}40 \\
40 \\
46\end{array}$ \\
\hline
\end{tabular}


slow growth was observed with $0.006 \%$ formaldehyde, but none with $0.008 \%$. The phenol efficiency was slightly altered by acidity; at $\mathrm{pH} 5.3$, complete inhibition was obtained by $0.12 \%$, while at $\mathrm{pH} 3.1$, slow growth was observed with $0.14 \%$.

The effect of phenol consisted largely in a decrease of the rate of multiplication (Fig. 24). There was no increase in the lag phase. The generation times, computed from plate counts, are represented in Table 25. Direct microseopic counts of dead cells were also made after mixing 1 cc. of the phenol-treated cultures with 1 cc. of of $0.01 \%$ methylene blue solution. The proportion of dead cells never exceeded 5\%. 'This observation permits the conclusion that the increased generation time was not the result of excessive death in a population which otherwise was multiplying normally, but was due to a lower average growth rate. The final number of cells capable of growing with or without phenol was determined only roughly, but unquestionably it was smaller in the presence of the disinfectant.

Formaldehyde produced the same symptoms of decreased rate of multiplication and decreased maximal population, but in addition it caused a quite extended lag (Table 25 and Figure 24).

As far as the observations of the writer go, formaldehyde is the only strong disinfectant which causes such a marked prolongation of the lag period. Mercurochrome also increases the lag, but to a much lesser extent. The inhibition of growth by formaldehyde is so prolonged that in determining the phenol coefficient of this disinfectant, the usual observation time of 48 hours gives wrong results and must be extended to 4 days.

These two diluted disinfectants are alike in one respect: as long as the dose is sufficient to prevent growth, they kill the cells slowly but continuously. With weaker doses, a slow growth sets in, but many cells die before multiplication starts. The rate of multiplication de- 


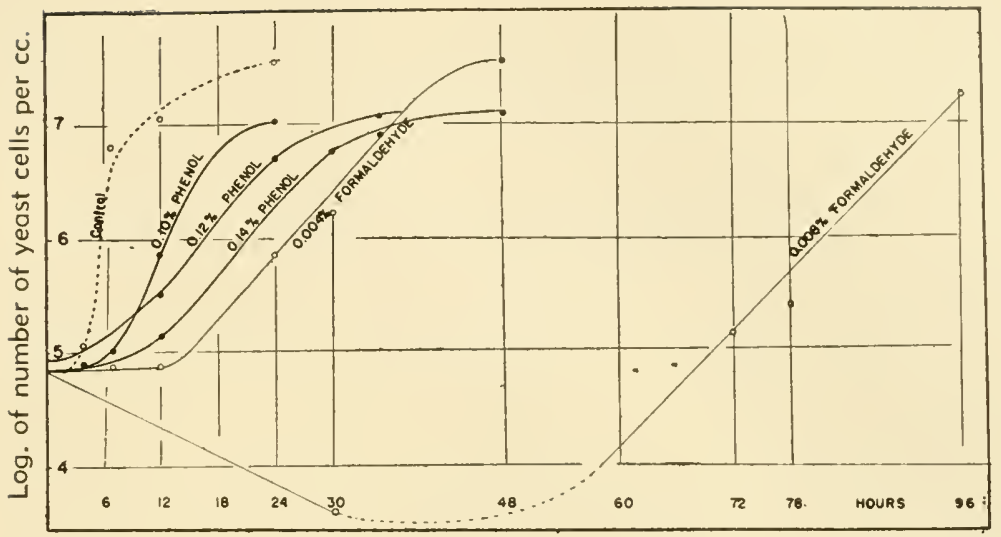

Fig. 24. Multiplication curves of Saccharomyces ellipsoideus in presence of various concentrations of phenol and formaldehyde. (Original data.)

creases as the concentration of the disinfectant increases, and becomes zero at the inhibitive dose.

In addition to the decreased multiplication rate, formaldehyde causes a pronounced increase in the lag period which phenol does not show. Thus three types of interference are possible; extension of lag with normal growth rate, decrease of growth rate with normal lag, and decrease of growth rate plus extension of lag. All three types will be shown to actually occur.

Another question arises when diluted bactericides are used as antiseptics, namely, that of the ratio of inhibitory to bactericidal concentration. On this point quite extensive data have been presented by Birkhaug (1933), and the ratio was found to fluctuate greatly. Table 26 gives a few of the reported data. With the last three disinfectants, the inhibition of growth (without killing) of Bactcrium coli requires 30 to 40 times as high a concentration as the corresponding inhibition of Staphylococcus. But the dose necessary to kill Bucterium coli is only 3 to 4 times as high as that for Staphylococcus. If irreversible sterility (or death) were due to the same reaction as reversible sterility (or antisepsis), death 
should occur when antisepsis has reached a certain stage, e.g., when $99 \%$ of certain molecules are inactivated. The reaction could reach the same stage (death) at the same time (10 minutes) only if Bacterium coli were exposed to a concentration 40 times as high as that for Staphylococcus. However, the experiment shows that the concentration for death need be only 4 times as high for $\mathrm{Bac}$ terium coli. Therefore, disinfection has a different concentration coefficient than antisepsis, and that means a different reaction.

The above-mentioned experiments by Jean Conn have shown that the inhibiting concentration for yeast is $0.16 \%$ with phenol and $0.008 \%$ with formaldehyde. The killing concentrations are approximately $1.0 \%$ and $2.5 \%$ for 10 minute death times. The ratios of the killing to the inhibiting concentrations are thus: $1: 0.16=6.25$ and

TABLE 26

Inhibitory and lethal doses of mercury compounds.

(From Birkhaug, 1933.)

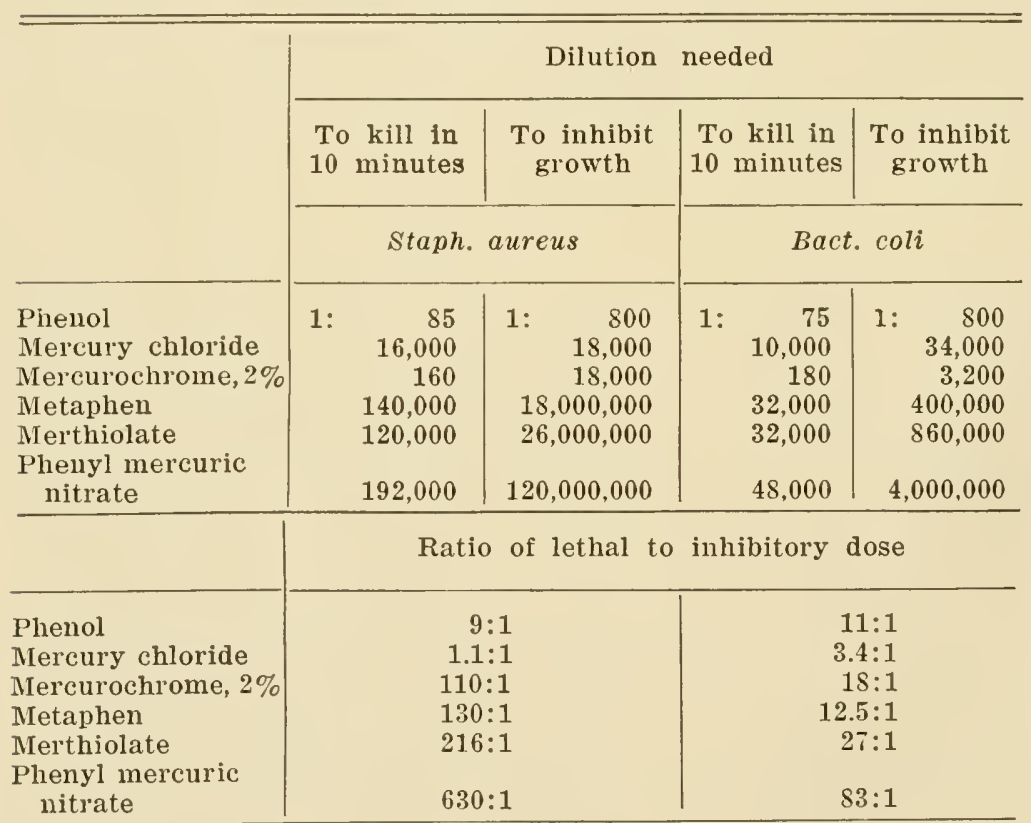


2.5:0.008 $=320$ respectively. The conclusion, here again, is that the reaction inlibiting multiplication seems to be different from that causing death.

\section{EFFECT OF SIZE OF INOCULUM}

Many statements ean be found in the literature to the effect that a certain concentration of an antiseptic will inhibit bacterial multiplication if the inoculum is small, while growth will take place if the inoculum is large (see references in paper's by MacLeod and Mirick, 1942, and by Lee et al., 1943). This may result from different causes. The most obvious is the presence of organic matter in the inoculum. Ordinarily, the inoculum consists of a small volume of culture which contains some organic matter besides the bacteria. Substances such as chlorine, iodine, or permanganate, react promptly with organic matter, and their concentration is thereby decreased. A small inoculum will have little influence, but a large inoculum may reduce the concentration of the antiseptic below the inhibiting dose. If the inoculum consists of washed cells, the effect of its size on the concentration of the antiseptic will be much smaller.

If the inoculum contains large colloid particles, antiseptics of the type of aniline dyes or hexyl resorcinol may be adsorbed, and the decrease of available antiseptic will be larger if the inoculum is larger.

Quite generally, if bacteria produce no visible growth in a medium containing an antiseptic, the cause of unobservable multiplication need not always be the same. It may be either the death of all the cells, or the permanent, though reversible inhibition of multiplication. But two other canses must also be considered, namely, too early a cessation of observation which did not give the bacteria enough time to produce visible turbidity, or too small an increase in numbers of bacteria to produce visi- 
ble turbidity. Each of these causes may, under certain conditions be modified by the size of the inoculum.

When antiseptics cause death, they act very slowly, and with many antiseptics, the lethal action ceases after some time. In the case of dyes, the survivors can gradually modify the antiseptic so that multiplication becomes possible. If $99 \%$ of the cells die before growth can start, all the cells of an inoculum of 50 cells may be killed, while with a large inoculum, a sufficient number will survive to start growth again. In this case, the bacteria themselves modify the antiseptic, namely, the dye, and make it less toxic (for details, sce next chapter).

With volatile substances like alcohol, chloroform, thymol, formaldehyde, etc., the concentration may gradually decrease by evaporation of the antiseptic from cultures closed by a cotton plug. With a small inoculum, all cells may be dead before the decrease in antiseptic permits multiplication, while a large inoculum has far greater chances of having some survivors.

Erroneous conchusions as to the effect of the size of the inoculum can further result from too short an observation time. The usual inoculation procedure consists in transferring a loopful $(0.01$ ce.) from a full-grown culture to a test tube containing the medium with the antiseptic. This amounts to an initial number of about a million cells per ce. of eulture. With medium-sized bacteria, turbidity becomes noticeable with about 5 million cells per ec. If the bacteria require 2 hours to double their number, they need only 3 generations or 6 hours to produce visible turbidity. To this must be added the lag period which would not be more than 3 hours with such a heavy inoculum. If the antiseptic decreases the rate of multiplication to one-fifth, bacteria would require 10 hours to double their number, and the total time to produce visible turbidity would be $30-3=33$ hours. This large inoculum wonld thus produce turbidity in 9 hours without antiseptic, and in 33 hours with antiseptic. 
If another set of cultures is made with only 1,000 cells per ce., instead of 1 million, we must add to the above figures the time needed by the bacteria to multiply from 1,000 to $1,000,000$. This corresponds to 10 generations, which require 20 hours without antiseptic, but 100 hours with antiseptic. We must further consider that a smaller inoculum demands a longer lag period, approximately 12 hours, in our ease, instead of 3 hours. Thus, the control culture without antiseptic would prodnce visible turbidity in $6+20+12=38$ hours while the culture with antiseptic would need $30+100+12=142$ hours $=6$ days. With a still smaller inoculum of only 1 cell per cc., the lag period would be about 24 hours, and the total time to produce turbidity would be 3 days without antiseptic and 10 to 11 days with antiseptic. Since experiments are often discontinued if no turbidity is noticeable after one week, an antiseptic may be believed to suppress multiplication completely, while bacteria have been increasing continnously, althongh at a very low rate. A decrease in the rate of multiplication has been observed with most antiseptics, e.g., with sulfanilamide, benzoic acid, $\mathrm{SO}_{2}$, penicillin, etc. Not all of them, however, cause also an increased lag period.

That an increased lag can give the appearance of complete inhibition of growth, is obrious See Fig. 25). Cruess and Richert (1929) found that in grape juice adjusted to $\mathrm{pH} 6.0$, benzoate of soda retarded yeast development greatly. With $0.6 \%$, growth began after 12 days, while with $0.8 \%$ growth started only on the 25 th day.

An interesting complication is encountered in the results of Lee, Epstein and Foley (1943) who studied the effect of urea on the development of Bacterium coli ('Table 27). Growth was recorded by turbidity measurements. (Roughly, the turbidity is linearly related to the population.) After 21 hours, the population was higher in the cultures containing urea than in those without it, especially with the smaller inocula. This indicates an in- 

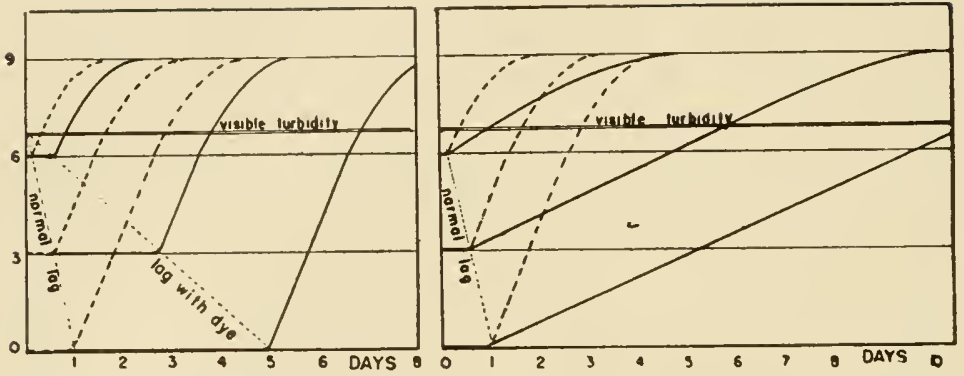

Fig. 25. Effect of the amount of inoculum on the time required for the development of visible turbidity in a bacterial culture, when the antiseptic prolongs the lag period (left), and when it retards the growth rate (right). The broken lines refer to controls, the solid lines to cultures with antiseptic. Abscissa: time; ordinate: logarithm of the number of bacteria per cc.

creased growth rate. But the 5-hour measurements show a decrease of growth caused by urea. The two observations can be explained only by the assumption that urea prolongs the lag phase, but increases the growth rate. The example indicates how important it is to consider these two phenomena separately.

\section{THE DUAL ACTION OF THE DYES}

Dyes have been employed in the treatment of wounds as early as 1890, and since 1900 many attempts have been made to develop dye derivatives for chemotherapentic purposes. Several such compounds have now been in use for some time, but, in general, they have proved more effective against trypanosomes than against bacteria. The outstanding fruits of this search for therapentic agents are rivanol and germanin (Bayer 205).

Like many other antiseptics, dyes in high concentrations act as disinfectants, but high concentrations are rarely used. In the customary weak solutions, their effect differs from that of most antiseptics. The bacteria 
TABLE 27

Effect of size of inoculum on growth of Bacterium coli (shown by turbidity measurements), in cultures containing urea. A value of 30 indicates $650,000,000$ cells per cc. (From Lee, Epstein, and Foley, 1943.)

\begin{tabular}{|c|c|c|c|c|c|c|c|c|}
\hline $\begin{array}{c}\text { Number of cells per } \\
\mathrm{mm}^{3} \text { at start }\end{array}$ & \multicolumn{2}{|c|}{65} & \multicolumn{2}{|c|}{650} & \multicolumn{2}{|c|}{6,500} & \multicolumn{2}{|c|}{60,000} \\
\hline $\begin{array}{l}\text { Observation time } \\
\text { (hours) }\end{array}$ & 5 & 21 & 5 & 21 & 5 & 21 & 5 & 21 \\
\hline $\begin{array}{c}\text { Conc. of urea } \\
(\%)\end{array}$ & \multicolumn{8}{|c|}{ Turbidity } \\
\hline 0 & 0 & 14 & 3 & 19 & 18 & 36 & 28 & 32 \\
\hline 0.2 & 0 & 24 & 2 & 25 & 27 & 26 & 28 & 28 \\
\hline 0.5 & 0 & 26 & 2 & 28 & 16 & 32 & 34 & 29 \\
\hline 1.0 & 0 & 28 & 0 & 33 & 11 & 40 & 29 & 36 \\
\hline 2.0 & 0 & 26 & 0 & 25 & 9 & 24 & 28 & 35 \\
\hline
\end{tabular}

are inactivated only for a time; after a while they begin to grow in the presence of the dye, and then multiply at a normal rate, showing no trace of injury. It seems as if the dye merely prolongs the lag phase without producing any other effect. Churchman (1912) coined the term "bacteriostasis" for this phenomenon.

The difference between dye bacteriostasis and the decrease of growth rate caused by most other antiseptics is shown in Figure 26 . The graph on the left side shows the effect of rivanol (an acridine dye) on the oxygen absorption of Bacterium coli. Since the oxygen absorption is proportional to the bacterial concentration, the curves of Fig. 26 are really growth curves. The higher concentrations cause a longer lag, but they do not affect growth rates, as is indicated by the fact that the growth curves remain parallel. The graph of the right side represents the action of sulfa-tliazole. This compound lowers the growth rate; consequently the slope of the growth curves decreases when the concentration increases, and the curves spread out fan-shaped. All curves 
seem to have started at the same time; there was no increase of the lag period.

This very unusual effect of the dyes was explained by Dubos (1929) as due to a change of the oxidation potential of the medium by the dye. He showed that a Pneumococcus $R I I$ and a Streptococcus hemolyticus were inhibited only by those dyes whose oxidation potential was higher than that corresponding to an $\mathrm{rH}$ of 12.5 while they grew in all dyes with a lower potential.

Ingraham (1933) rerified Dubos' tentative explanation in an extensive study of the action of gentian violet. The relationship that she found between the length of the lag phase and the logarithm of the cell concentration is rectilinear and can be expressed by

$$
\operatorname{Lag}_{1}=\mathrm{Lagg}_{2}+\mathrm{k} \log \mathrm{N}_{2} / \mathrm{N}_{1}
$$

where $N_{2}$ represents the larger and $N_{1}$ the smaller inoculum, and $\mathrm{Lag}_{2}$ and $\mathrm{Lag}_{1}$ the corresponding lag phases. The proportionality constant $k$ depends upon the species as well as on the medium. She furthermore showed that a large inoculum may be capable of adjusting the potential to the optimum of cell growth so that the bacteria can multiply again, while a small number of cells is not able to accomplish this change.

Hoffmann and Rahn (1944) separated the bactericidal from the bacteriostatic action. In concentrations over 4 ppm. of crystal violet (the purest form of gentian violet available), in which Streptococcus lactis was killed, the order of death was logarithmic, and the deathrate constant was practically proportional to the dye concentration $K=0.037 \mathrm{c}$, where $c$ is the concentration in ppm. (See Table 28). Death is probably due to the reaction of the dye with some cell constituent essential for a vital function such as cell division, as Stearn and Stearn (1924) had claimed. It is not due to inactivation of enzymes, as Hoffmann's (1943) experiments proved. 
TABLE 28

Effect of crystal violet on Streptococcus lactis in broth cultures. (Original data.)

\begin{tabular}{|c|c|c|c|c|}
\hline \multicolumn{2}{|c|}{ Crystal Violet } & \multicolumn{2}{|c|}{$\begin{array}{c}\text { Deathrate constant } \\
K\end{array}$} & \multirow{2}{*}{$\begin{array}{l}\text { Beginning of } \\
\text { growth }\end{array}$} \\
\hline Dilution & ppm. & Calculated & Measured & \\
\hline $1: 1,500,000$ & 0.67 & 0.025 & 0.08 to 0.16 & after 31 hours \\
\hline $1,000,000$ & 1 & 0.037 & 0.09 to 0.17 & after 3 days \\
\hline 750,000 & 1.33 & 0.050 & 0.08 to 0.11 & no growth in 3 days \\
\hline 500,000 & 2 & 0.074 & 0.16 to 0.19 & “ \\
\hline 400,000 & 2.5 & 0.093 & 0.12 to 0.20 & no growth in 2 days \\
\hline 250,000 & 4 & 0.148 & 0.11 to 0.30 & " \\
\hline 200,000 & 5 & 0.185 & 0.19 to 0.21 & “ \\
\hline 100,000 & 10 & 0.370 & 0.34 to 0.37 & “ \\
\hline 50,000 & 20 & 0.740 & 0.67 to 0.80 & “ \\
\hline 10,000 & 100 & 3.700 & 3.13 to 5.36 & “ \\
\hline
\end{tabular}
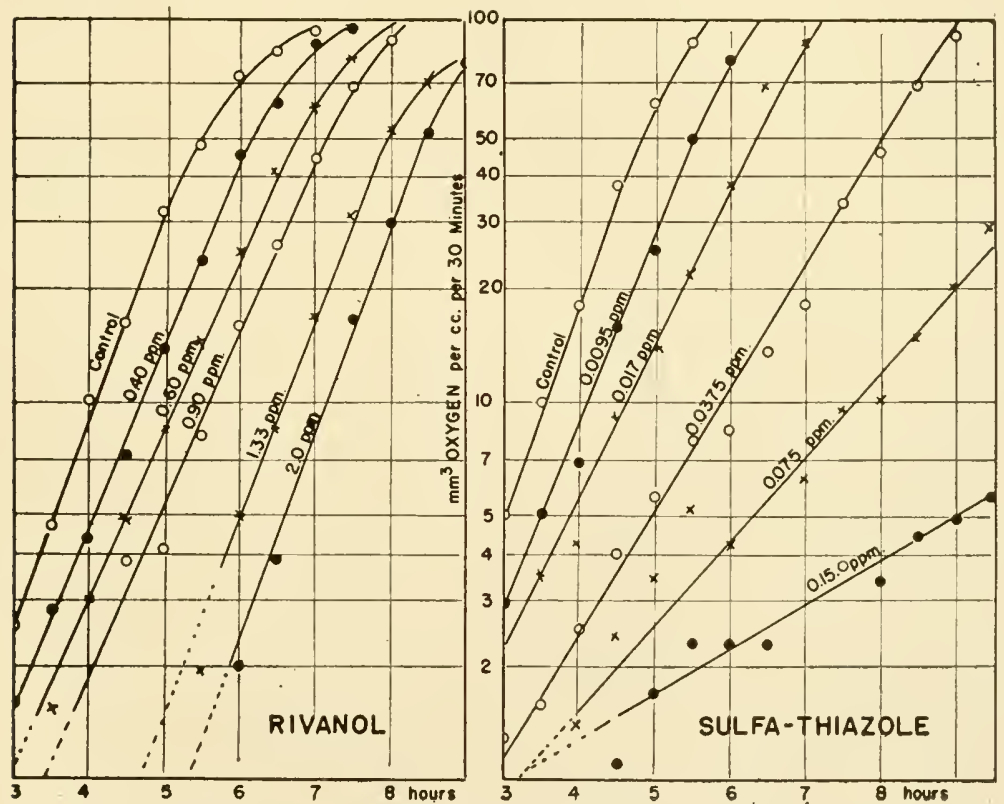

Fig. 26. Different types of antiseptic action. Left: multiplication curves of Bact. coli obtained with various concentrations of rivanol, a dye which increases the lag period but does not affect the growth rate; the curves are parallel. Right: multiplication curves of Bact. coli obtained with various concentrations of sulfathiazole, a dye which retards the growth rate, but does not affect the lag; the curves spread out fan-shaped. In the two graphs the oxygen consumption is considered a measure of the number of organisms. Abscissa: time in hours; ordinate: oxygen consumption, on logarithmic scale. (From data of Hirsch, 1942.) 
In solutions containing less than $4 \mathrm{ppm}$. of crystal violet, the death rate of $S$. lactis did not change with the dye concentration, but remained nearly constant. The bacteria were still dying at these low concentrations, and the order of death was logarithmic for a while, but later the death rate decreased. If the inoculum had been sufficiently large, the surviving bacteria would have begun to grow in the presence of the dye which a short time ago had killed the majority of the inoculated cells, and they would have multiplied as rapidly as if no dye were present.

The fact that the death rate is independent of the concentration in the range below 4 ppm. and that bacteria multiply later withont any indication of injury fits well into the explanation given by Dubos. In dilute dye solutions bacteria will die largely on account of the abnormal reduction potential which is the same in high and low concentrations of the dye. Of conrse, some cells are also dying from the direct reaction of some of their constituents with erystal violet, but in these great dilutions, the rate of death from that cause will be very low and become negligible in comparison with the rate of death from the abnormal potential.

Bacteria can change the potential of this medium as they change that of any other medium in which they grow. The change is brought about by their metabolism, largely by their reducing power. If the inoculum is large, the change is rapid; if it is small, the change is slow. With a very small inoculum, all cells may be dead before the potential is sufficiently adjusted to permit growth. Once the potential is adjusted, multiplication is not impeded, and the rate of multiplication is not decreased by the dye. Hoffmamn and Rahn also showed that aeration lengthens the time of "recovery" of the culture because it keeps the oxygen concentration of the medinm high, and counteracts the reduction by bacteria while removal of oxygen hastens it. The marked effect of 
$\mathrm{pH}$, which controls the reduction potential, on the length of lag is shown in Figure 27 .

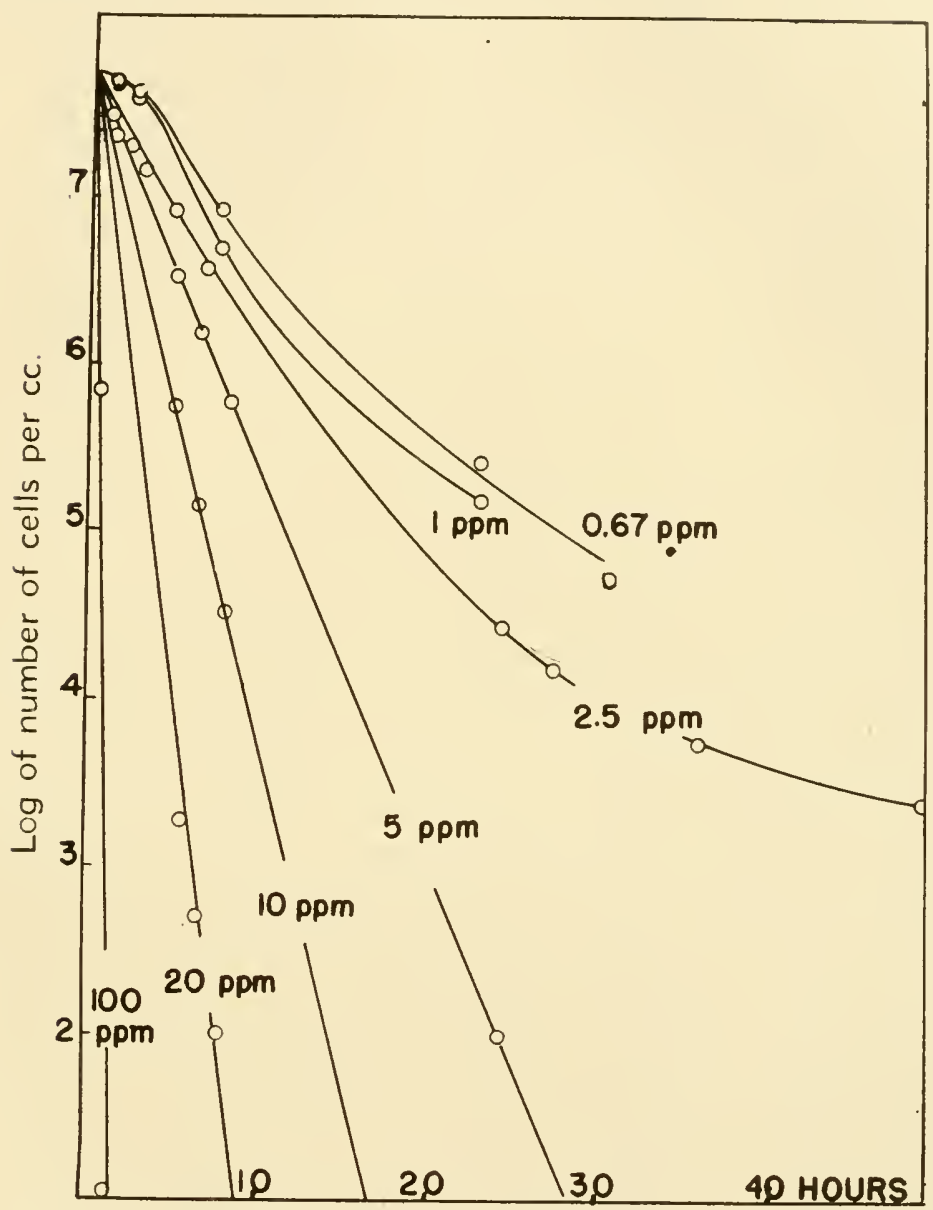

Fig. 2i. Survivor curves of streplococeus iactis treated with various concentrations of crystal violet. (From data of Hoffmann, 1943.)

The assumption of a dual role of the dyes is supported by their effect on cells of different ages. The stronger solutions of crystal violet kill young cells more rapidly than old ones, as in fact, all disinfectants do ${ }^{1}$. In dilute solutions, multiplication sets in sooner when the 
cells are very young because young cells have a much more active metabolism than old ones, and therefore can adjust the potential more readily than old, resting cells.

That an unfarorable oxidation-reduction potential retards or prevents multiplication is common knowledge. That it kills the bacteria fairly readily represents a new experience. Ingraliam (1933) made the statement that bacteria are not killed by crystal violet, but Hoffmann's numerous data (1943) show that even with dilute dyes, $99 \%$ and more of the cells are killed before multiplication begins. That these cells are really dead is evidenced by the fact that activated charcoal, which remores all crystal violet from the culture in less than a minute, did not restore in them the faculty of reproduction.

If antisepsis by dyes is due to the establishment of a redox potential too high for multiplication, the species with the strongest reducing power, the Clostridia, should be the most tolerant to dyes, with the colon group as a close second, while the strict aerobes should be more sensitive than the streptococci. Ingraham has arranged 20 species in order of increasing sensitivity, and, with a few exceptions, the observed order agrees with that which general conceptions of "reducing power" in these species would predict. Clostrilia are, in fact, the most tolerant species, while the aerobic spore-formers and the aerobic yeasts Torula and Monilia are the most sensitive ones. The observation of Slanetz and Rettger (1933) that the fusiform bacteria can tolerate gentian violet in concentrations of $500 \mathrm{ppm}$. (1:2,000 dilution) fits into the picture because this group consists of strict anaerobes. The highly selective action of this and other dyes is probably not connected with the Gram staining reaction, as is commonly thought, but depends npon the reducing power of the species. Becanse of this selectivity, some dyes have been added to special culture media to suppress certain groups while permitting others to grow. 
The quantitative relations between the length of the lag period and cell concentration, established by Ingraham (p. 138) were verified by Hoffmimn (see Fig'. 28). This is difficult to explain. If one culture were inoculated with 1000 times as many bacteria as the other, metabolism would be 1000 times as intense and adjustment of potential 1000 times as fast, so that the favorable potential should be reached in one-thousandth of the time. The length of the lag period would be one-thousandth of $\mathrm{Lag}_{1}$, while in reality the relation is

$$
\begin{aligned}
\operatorname{Lag}_{1000} & =\operatorname{Lag}_{1}+\mathrm{k} \log 1 / 1000 \\
& =\operatorname{Lag}_{1}-3 \mathrm{k}
\end{aligned}
$$

$l_{i}$ being a proportionality constant. No explanation of this phenomenon has been offered.

The antiseptic power of dyes is greatly affected by the acidity of the medium (see Fig. 29). Acid dyes (e.g. acid fuchsin, eosin)-which in general are rather weak

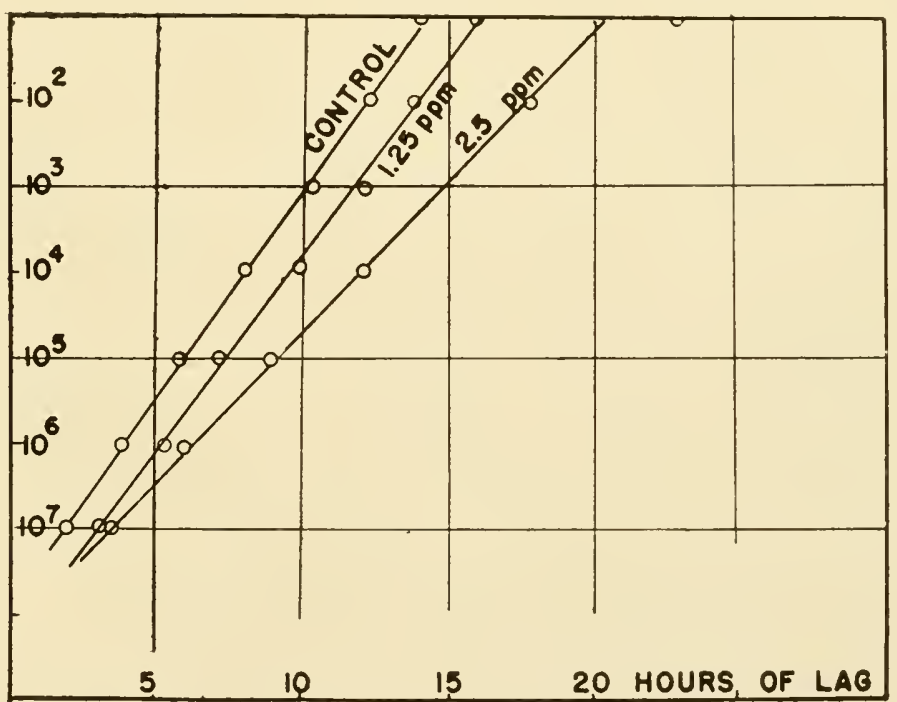

Fig. 28. Effect of the amount of inoculum on the length of the lag phase of Bacterium coli treated with crystal violet. Abscissa: lag phase; ordinate: concentration of inoculum in number of bacteria per cc., on logarithmic scale. (From data of Hoffmann, 1943.) 
antiseptics-act most efficiently in acid media, while basic dyes (e.g., gentian violet, basic fuchsin, all flavine dyes) are more bacteriostatic in alkaline media (see Table 29). Hoffmann (1943) found that with gentian violet, only the bacteriostatic effect changes with $\mathrm{pH}$ while the bactericidal effect is not altered appreciably. As the reduction potential of dyes and of most culture media is greatly affected by $\mathrm{pH}$, it is not surprising that their bacteriostatic action changes correspondingly. Hoffmamn furthermore showed that the effect of acidity upon bacteriostasis had nothing to do with the electrolytic dissociation of the dye.

While the investigation of the detailed antiseptic mechanism of the dyes has been worked out almost entirely with erystal violet, the principles apply to many other dyes. As already mentioned, Dubos (1929), comparing the effect of 15 dyes, found that the oxidized indo-

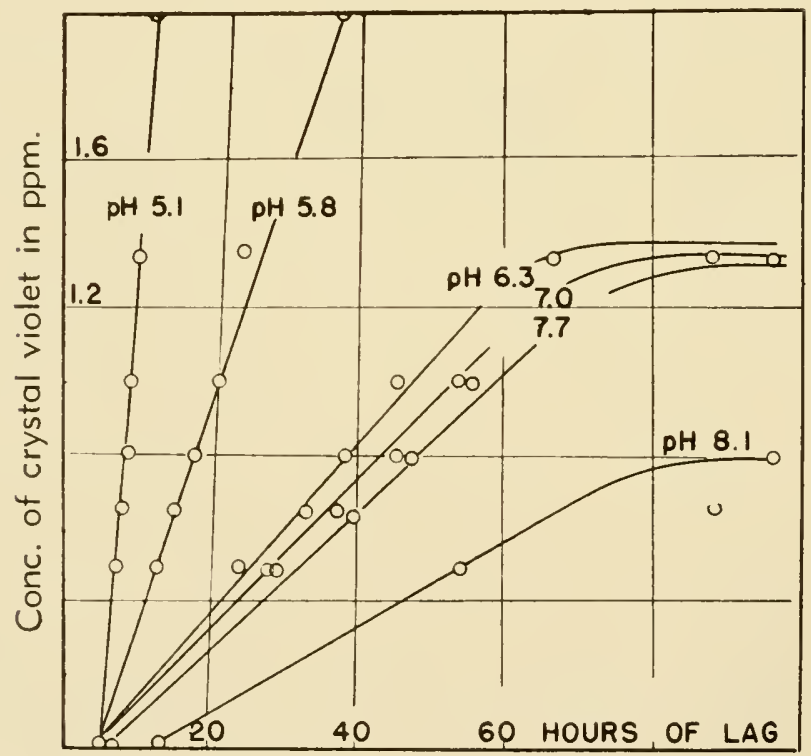

Fig. 29. Effect of acidity on the length of the lag phase of streptococcus lactis treated with various concentrations of crystal violet. (From data of Hoffmann, 1943.) 
TABLE 29

Bacteriostasis of Bacterium coli by various dyes. (From Stearn and Stearn, 1926.) + indicates growth; - indicates no growth.

\begin{tabular}{|c|c|c|c|c|c|c|}
\hline & \multicolumn{6}{|c|}{ Basic Dyes } \\
\hline $\mathrm{pH}$ & 4.95 & 5.28 & 6.23 & 6.46 & 7.16 & 7.73 \\
\hline Dilution & \multicolumn{6}{|c|}{ Gentian Violet } \\
\hline $\begin{array}{r}1: \quad 10,000 \\
20,000 \\
30,000 \\
70,000 \\
100,000 \\
200,000 \\
\end{array}$ & & $\begin{array}{l}+ \\
+ \\
+ \\
+ \\
+\end{array}$ & $\begin{array}{l}- \\
+ \\
+ \\
+ \\
+\end{array}$ & & $\begin{array}{l}z \\
z \\
+ \\
+\end{array}$ & $\begin{array}{l}\bar{z} \\
\overline{-} \\
\overline{+}\end{array}$ \\
\hline \multirow[b]{2}{*}{$\begin{array}{r}50,000 \\
75,000 \\
150,000 \\
300,000 \\
600,000 \\
\end{array}$} & \multicolumn{6}{|c|}{ Brilliant Green } \\
\hline & $\begin{array}{l}- \\
+ \\
+ \\
+ \\
+\end{array}$ & $\begin{array}{l}- \\
+ \\
+ \\
+\end{array}$ & & $\begin{array}{l}- \\
- \\
+ \\
+\end{array}$ & $\begin{array}{l}- \\
+ \\
+ \\
+ \\
+ \\
+\end{array}$ & \\
\hline \multirow{4}{*}{$\begin{array}{l}10,000 \\
20,000 \\
30,000 \\
70,000 \\
\end{array}$} & \multicolumn{6}{|c|}{ Methyl Violet } \\
\hline & & $\begin{array}{l}+ \\
+ \\
+ \\
+\end{array}$ & $\begin{array}{l}+ \\
+ \\
+\end{array}$ & & $\bar{z}$ & $\bar{z}$ \\
\hline & & \multicolumn{5}{|c|}{ Acid Dyes } \\
\hline & $\mathrm{pH}$ & 4.95 & 5.28 & 6.23 & 7.16 & 7.73 \\
\hline \multicolumn{2}{|l|}{ Dilution } & \multicolumn{5}{|c|}{ Acid Fuchsin } \\
\hline \multicolumn{2}{|l|}{$\begin{array}{r}25 \\
50 \\
75 \\
100\end{array}$} & & $\begin{array}{l}- \\
-\end{array}$ & $\overline{-}$ & $\begin{array}{l}+ \\
+ \\
+\end{array}$ & $\begin{array}{l}+ \\
+ \\
+ \\
+\end{array}$ \\
\hline \multirow{2}{*}{\multicolumn{2}{|c|}{$\begin{array}{r}25 \\
50 \\
75 \\
100 \\
\end{array}$}} & \multicolumn{5}{|c|}{ Eosin } \\
\hline & & & $\bar{z}$ & $\begin{array}{l}+ \\
+ \\
+\end{array}$ & $\begin{array}{l}+ \\
+ \\
+\end{array}$ & $\begin{array}{l}+ \\
+ \\
+ \\
+\end{array}$ \\
\hline & & \multicolumn{5}{|c|}{ Acid Violet } \\
\hline $\begin{array}{r}25 \\
50 \\
75 \\
100 \\
\end{array}$ & & $\frac{-}{ \pm}$ & & $\begin{array}{l}- \\
+ \\
+\end{array}$ & $\begin{array}{l}+ \\
+ \\
+ \\
+\end{array}$ & \\
\hline
\end{tabular}

*The color of brilliant green fades out at $\mathrm{pH}$ above 7.0 . 
phenols and methylene blue were bacteriostatic for Pneumococcus and most hemolytic streptococei, while the indigoes, malachite green and the indophenols were not toxic. In the reduced state, methylene blue and the indophenols were not toxic either.

\section{MODE OF ACTION OF THE SULFONAMIDES}

The antiseptic properties of sulfanilamide and its derivatives have probably been studied more intensely than those of all other antiseptics combined. The review by Henry (1943) lists 291 references. The sulfonamides are not strong disinfectants, but owe their fame to their ability to prevent, in concentrations which do no great damage to blood or tissues, multiplication of many species of bacteria.

The sulfonamides differ from all other antiseptics in that they do not affect the bacteria at once, but require a measurable amount of time before bacterial growth is retarded. The delay varies greatly, usually from 2 to 6 hours, according to Henri's compilation of data from seven author's. With all other antiseptics, the degree of growth retardation is uniform as long as the culture grows, or if the rate of multiplication occasionally varies, it may increase, as with crystal violet, but it never is normal at the start and decreases later. The writer has checked all his plate count and turbidity records of the early stages of antisepsis by phenol, formaldehyde, benzoic and sulfurous acid, and in every case multiplication was promptly retarded even by small doses. A picture like that of Figure 30, which was obtained by Muir, Shamleffer and Jones (1942) in their study of the effect of sulfathiazole on Bact. enteritidis is characteristic only of sulfonamides. These authors observed that Bact. enteritidis treated with sulfathiazole multiplies for a short time quite normally, but after about 3 genera- 


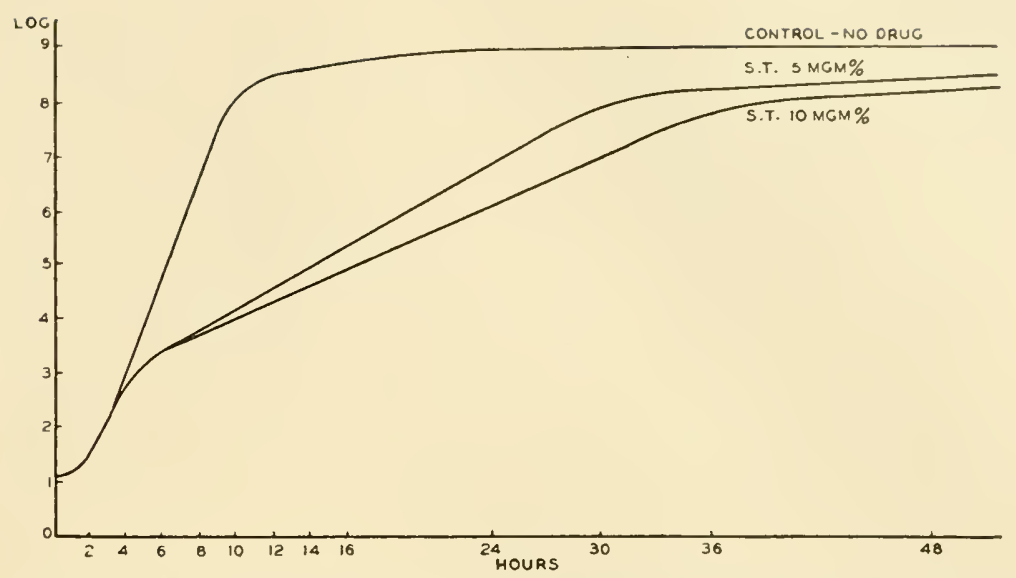

Fig. 30. Multiplication curves of salmonella enteritidis with and without sulfathiazole. Abscissa: time in hours; ordinate: logarithm of the number of organisms per cc. (From Muir, Shamleffer and Jones, 1942.)

tions the generation time in broth increases from 17 to 90 minutes with 50 ppm. thiazole and to 120 minutes with $100 \mathrm{ppm}$. In a syuthetic medium, $6 \mathrm{ppm}$. is sufficient to stop growth completely after multiplication has taken place quite normally for 10 hours. The type of curve suggests a deficiency of a necessary cell construction material in the medium.

This delay is not caused by a very slow penetration of the drug into the cells, as is proved by the fact that the luminescence of three species of photogenic bacteria was inhibited without delay as soon as the cells came in contact with sulfanilamide (Johnson and Moore, 1941).

The assumption of a slow penetration is also contradicted by the following studies of Kohn and Harris (1941a) with resting cells: They inoculated Bacterium coli into two tubes of culture medium held at $5^{\circ}$, one of which contained a retarding dose of sulfonamide. (At $5^{\circ}$, Bacterium coli does not grow.) After 3 hours, an equal amount of sulfonamide was added to the other tube, and both were incubated at $30^{\circ}$. The delay of the growth re- 
tardation was the same; the contact of the resting cells with the drug for 3 hours had been without any influence. In another experiment, the bacteria were held without food in presence of sulfonamides for 3 hours at $37^{\circ}$. When the food was added, the culture multiplied normally for a while, thus showing that the delay of the drug effect had not been changed by a 3-hour contact of the culture with the drug, becanse there had been no growth. Both experiments were made with four different sulfonamides. The authors concluded that "the interaction between the sulfonamide and the bacterium, therefore, depends upon some reaction associated intimately with growth".

Another noteworthy difference between sulfonamides and other antiseptics has been pointed ont by Kohn and Harris (l.c.). It concerns the relation between concentration and retardation of growth. Tery much more sulfonamide is required to produce strong retardation than slight retardation. Their main data are given in Table 30, together with results obtained by the writer

TABLE 30

Retardation of growth of Bacterium coli and of yeast by various antiseptics.

\begin{tabular}{l|c|c}
\hline Antiseptic & $\begin{array}{c}\text { Concentration required to reduce } \\
\text { the growth rate }\end{array}$ & $\begin{array}{c}\text { Ratio of the } \\
\text { two } \\
\text { concentrations }\end{array}$ \\
\hline
\end{tabular}

Bacterium coli (Kohn and Harris, 1941a)

\begin{tabular}{|c|c|c|c|}
\hline Sulfanilamide & $500 \times 10^{-6} \mathrm{M}$ & $\times 10^{-6} \mathrm{MI}$ & 10 \\
\hline Sulfapyridine & 20 & 2500 " & 125 \\
\hline Sulfathiazole & $4.2 "$ & 500 & 120 \\
\hline Sulfadiazine & 0.84 & 1000 & 1200 \\
\hline
\end{tabular}

Yeast (Rahn, unpublished data)

\begin{tabular}{l|l|l|l}
\hline Phenol & $0.10 \%$ & $0.17 \%$ & 1.7 \\
Formaldehyde & $0.003 \%$ & $0.007 \%$ & 2.3 \\
Benzoic acid & $0.015 \%$ & $0.040 \%$ & 2.7 \\
\hline
\end{tabular}


with other antiseptics. The table shows the concentrations necessary to decrease the growth rate $30 \%$ and $85 \%$. The difference between them is significant. It is usually explained by the assumption that a low concentration of sulfonamide retards growth slightly by attacking only one locus of the cell constituent inrolved in the reaction. Greater retardation can be brought about by an attack on other loci, or possibly by some secondary reaction between the drug and the cell constituents, which would cause a shift of equilibrium, and require a much higher concentration of the drug. Several authors have reported indications that other loci are attacked by larger doses. However, this implies that the first retardation is not increased by higher concentrations, and this implication again would make the action of sulfonamides different from that of all other antiseptics.

The frequently encountered statement, that retardation of multiplication is caused by a reaction of the sulfonamides with catabolic enzymes of the cell, has very little experimental support. Many investigators have shown that large doses will retard or inhibit enzyme action, but the same is true with large doses of sodium chloride. The inhibition of enzyme action by large doses of any compound can certainly not be considered proof that growth retardation by small doses is due to decreased enzyme action. In order to prove that retardation of growth is caused by enzyme inactivation, it is necessary to demonstrate that enzymes are affected by doses causing a slight retardation of growth, say 20 to $30 \%$. As early as 1937, Mellon and Bombas measured by the Thunberg technique the effect of sulfanilamide on the dehydrogenase of Pneumococcus Type I, and found that even a concentration as high as $0.17 \%$ did not decrease enzyme activity whereas $0.01 \%$ decidedly retarded growth. Barron and Jacobs (1937) rerified this observation for other species. Chu and Hasting's (1938) observed small decreases (occasionally, however, as high as 50\%) in the 
oxygen uptake of pneumococcus by doses which inhibited growth ahmost completely. Kohn and Harris (1941) found that a notable decrease in the respiration of Bact. coli occurred only with very large doses of sulfonamides. Amounts which produced a 30\% retardation of growth did not affect the oxygen uptake.

The results of Dorfman et al. $(1940,1941)$ with dysentery bacteria deal almost entirely with the interaction between nicotinic acid and some sulfonamides, which has nothing to do with the fundamental sulfonamide effect, because sulfunilamide does not show this reaction. The few data which can be applied to the main problem show that a much larger dose is needed to retard respiration than to retard growth. Growth was retarded slightly by $1 \mathrm{mg}$. in 100 cc., it was completely inhibited by 30 mg., but $120 \mathrm{mg}$. were needed to produce a $15 \%$ decrease of the oxygen uptake.

This agrees well with the extensive study by Hirsch (1942). Table 31 shows some of his data. While 0.15 ppm. of sulfathiazole reduces the multiplication rate of Bacteriu coli $75 \%$, 255 ppm., or 1700 times the growth-

TABLE 31

Effect of sulfa-thiazole on Bacterium coli. (From Hirsch, 1942.)

\begin{tabular}{|c|c|c|}
\hline $\begin{array}{l}\text { Concentration: } \\
\text { (mg. per liter) }\end{array}$ & $\begin{array}{c}\text { Respiration: } \\
\left(\mathrm{mm} \cdot 3 \mathrm{O}_{2} \text { in } 4 \mathrm{hrs.}\right)\end{array}$ & $\begin{array}{l}\text { Generation time } \\
\text { (in minutes) }\end{array}$ \\
\hline 255 - & 130.1 & no growth \\
\hline 102 - & 136.9 & “ \\
\hline 40.75 & 139.3 & “ \\
\hline 16.4 & 137.8 & “ \\
\hline 2.62 & 131.5 & “ \\
\hline 0.15 & .... & 128 \\
\hline 0.075 & $\ldots$. & 83 \\
\hline 0.0375 & .... & 60 \\
\hline 0.0189 & $\ldots$. & 53 \\
\hline 0.00945 & ..... & 35 \\
\hline Control & 135.1 & 31 \\
\hline $\begin{array}{l}\text { Estimated number } \\
\text { of cells per cc. }\end{array}$ & $200,000,000$ & $4,000,000$ \\
\hline
\end{tabular}


retarding dose, does not decrease the oxygen uptake at all.

Greig and Hoogerheide (1941), working with sulfanilamide, came to the conclusion that "germicides in bacteriostatic concentrations have no effect on metabolic rates (oxygen uptake) of bacteria, but inhibit multiplication'.

MacLeod reported (1939) that sulfapyridine in doses of $125 \mathrm{ppin}$. retards the action of the dehydrogenase of pneumococci for glycerol, lactate and pyruvate, but not that of glucose-dehydrogenase. No records are given about the tolerance of the bacteria involved, but it seems safe to assume from a preceding paper by MacLeod and Daddi (1939) that $60 \mathrm{ppm}$. caused complete inhibition of the original strain.

The only data showing a real correlation between retardation of respiration and retardation of growth are those of Serag and Shelburne with streptococei (1942a) and pneumococci (1942b). The parallelism is rery striking in some of the experiments with streptococci in which the sulfonamides reduced both the oxygen consumption and the rate of multiplication by the following amounts:

Decrease in

oxygen consumption

$59 \%$
$62 \%$
$68 \%$
$64 \%$
$64 \%$
Decrease in rate of multiplication

$59 \%$

$66 \%$

$65 \%$

$69 \%$

$64 \%$

An equally close agreement was obtained with anaerobic cultures where the formation of acid was measured.

These results contradict all the others previously mentioned, probably because they represent abnormal growth conditions. Serag and Shelburne used inocula of nearly a billion cells per ce., that is, about the maximal population obtainable in broth. They also used very large 
amounts of sulfanilanide. While the concentration of the latter needed to retard by $85 \%$ the growth of B.coli is $0.005 \mathrm{M}$, they use 8 times as much $(0.04 \mathrm{M}$ or $0.69 \%)$ for the much nore semsitive streptococcus.

Wyss, Strandskor and Schmelkes (1942), following: the Sevag technique, obtained a decrease of $20-28 \%$ in the oxygen uptake of Strep. pyogenes with 0.04 M sulfanilamide, but the same or larger decreases were obtained with the ortho and meta derivatives which are chemotherapeutically inactive. The results with Bact. coli and Staph. aureus were similar. If these compounds retard respiration without producing the true sulfonamide action, we cannot very well explain the sulfonamide action as the result of retarded respiration. The same conclusion must be reached from the findings of Sevag" that "approximately $65 \%$ inhibition of aerobic respiration or approximately $45 \%$ inhibition of anaerobic respiration results in (or accompanies) complete bacteriostasis."

This ehecks with Ely's result (1939) that the respiration of Bact. coli is decreased about $50 \%$ by $0.8 \%$ sulfanilamide, "with little or no killing of bacteria". In other words, multiplication ceases completely when the cells are capable of producing 35 to $55 \%$ of their energy by respiration or fermentation.

However, bacteria do not cease growing under such eireunstances. Foter and Rahn (1936) have shown that at low temperatures, streptococci and lactobacilli need only half as much energy for doubling their number as at the optimum temperature, but are capable of multiplying slowly and continnously with only $5 \%$ of the energy output observed at the optimal temperature. The complete inhibition of multiplication of cells which still show respiration or fermentation cam be due only to a

1. Quoted from Henry (1943), p. 226. 
reaction of the drug with some cell constituents which are more directly related to growth or cell division.

The first attempt to explain sulfonamide action on bacteria as a direct effect on the growth mechanism is probably that by MeIntosh and Whitby (1939) who stated: "Sulfonamide drug's are not simple germicides. They probably act by neutralization of some metabolic function or enzymatic activity". This idea was elaborater by Wood (1940) who observed that the effect of sulfanilamide is counteracted by $p$-amino benzoic acid. This compound, which is found in small amounts in peptone and meat extract, is necessary for the formation of certain indispensable cell constituents. Many bacteria can synthesize it. Those species which produce it freely, e.g., bacteria of the colon group, are able to tolerate large doses of sulfonamides. Resistant variants of sensitive species have been shown to produce greater amounts of $p$-amino benzoic acid than their parent strains (Landy and assoc., 1943).

All sulfonamides are "antagonized" by $p$-amino benzoic acid, and this antagonism can be explained in sereral ways: 1 . The sulfonamide may combine with $p$-amino benzoic acid and make it massimilable. (That explanation, however, has been disproved.) 2. The sulfonamide may interfere with that part of the cell which synthesizes p-amino benzoic acid. 3. On account of the great similarity of the two compounds, the srnthetic mechanism of the cell may use sulfanilamide instead of $p$-amino benzoic acid and build it into cell structures which then

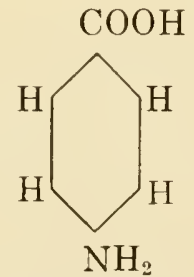

p-amino hruzoic acid

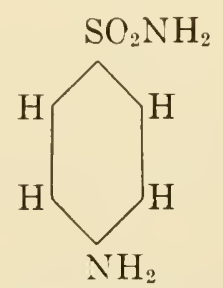

sulfanilamide 
fail to function because of the abnormal sulfone sidechain. This would cause a retardation of growth proportional to the number of abnormal side-chains per cell, and eventually a complete cessation of growth. The compounds thus incapacitated may inchude enzymes, but the decrease of enzymatic activity would be the result rather than the cause of abnormal growth.

The delayed action of sulfonamides can be explained by postulating a certain store of $p$-amino benzoic acid in the cell. The sulfonamide cannot retard growth until this store is exhausted. The results of Fig. 30 agree well with the assumption that the new cells are accumulating increasing numbers of inactive, or one might say, defunct molecules.

A very interesting parallel to the above case has been obtained with the sulfone derivative of nicotinic acid. Mcllwain (1940) tested the action of pyridine sulfonic acid amide on bacteria which need nicotinic acid amide. The compound retarded the growth of staphylococci, and this effect could be counteracted by nicotinic acid amide, just as that of sulfonamides is counteracted by $p$-amino benzoic acid. In a later publication (1942) he gave as further example of this phenomenon the counteraction of $\alpha$-amino sulfonic acids by $\alpha$-amino carboxylic acids in Proteus, and of acriflavine by amino acids in Bact. coli. The above explanations are often presented in various forms. Johnson (1942) considered all of them improbable because one molecule of $p$-amino benzoic acid is sufficient to neutralize the effect of 23,000 molecules of sulfanilamide on luminescent bacteria.

Fox and Rose (1942) explained this ratio as resulting from the ionization of sulfonamides, the small dissociated fraction only being effective. They tested the minimum growth-retarding dose of the drug at $\mathrm{pH} 7$, and the minimum dose of $p$-amino benzoic acid which would neutralize the effect. The ratio obtained varied greatly from one to the other of the four sulfonamides tested, as 
may be seen in the following table, but when the amount of dissociated drug was computed it was found not to differ nuch for the four compounds. Thus, although the actual amounts of sulfa drugs which were needed to retard growth were high as compared to those of $p$-amino benzoic acid, the concentrations of dissociated drug were not very different from those of the acid, their ratio being in the neighborhood of 1 .

Sulfanilamide

Ratio of $\mathrm{PABA}^{1}$ to drug

Sulfapyridine Sulfathiazole

Sulfadiazine

$\begin{array}{lr}1: 5,000 \\ 1: & 40 \\ 1: & 8 \\ 1: & 8\end{array}$

Ratio of $\mathrm{PABA}^{1}$ to dissociated drug

$1: 1.4$

$1: 1.4$

$1: 4.9$

$1: 6.4$

1. $p$-amino benzoic acid.

Bell and Roblin (1942) reasoned that the more a sulfonamide resembles $p$-amino benzoic acid, the greater its bacteriostatic effect should be. In an extensive study, they measured the two dissociation constants of 50 sulfonamides, and a very definite correlation between acidic dissociation and antiseptic efficiency was found. "The more negative the $\mathrm{SO}_{2}$ group of an $\mathrm{N}^{1}$-substituted sulfanilamide derivative, the greater is its bacteriostatic power."

Kumler and Daniels (1943) point to some inconsistencies in the data of Bell and Roblin, and believe that the main factor in bacteriostasis is the balance of electric charges in the molecule. They explain the activity of the sulfonamides primarily by "the contribution of resonating form with a coplanar amino group. The negative character of the $\mathrm{SO}_{2}$ group is a concomitant factor associated with this resonating form"; it is not the primary factor as Bell and Roblin thought.

The understanding of the action of sulfonamides is complicated by the discovery of other antagonizing sub- 
stances. Methionine counteracts low concentrations of sulfonamides, but not larger doses (Kohn and Harris, $1941,1942)$. These author's designate as "secondary antagonists", some other substances with similar effects, such as xanthine, serine, glycine, which function only in the presence of methionine.

Several other amino acids have been claimed to be antagonistic to sulfonamide retardation of growth, and even mercuric chloride can produce this effect, according to Lamamna and Shapiro (1943).

Snell and Nitchell (1943) found purines to be antagonistic to sulfanilamide, but only in the presence of very small amounts of $p$-amino benzoic acid. Quite generally, substances which are excellent foods and increase the growth rate materially, have a slight antagonistic effect which, however, cannot be considered specific.

The picture of the mode of action of sulfonamides is still rather hazy and indefinite. But one of their characteristic features seems well established, it is that, in contrast to other antiseptics, they act more strongly on growing than on resting cells. The status of the cells is of great importance, and failure to realize this is probably the reason for some seemingly contradictory evidence. The kind of medium used is also of importance since it may contain appreciable amounts of one or several antagonists.

Concerning the influence of temperature, White (1939) found that the efficiency of sulfanilamide is 10 times as high at $37^{\circ}$ as at $30^{\circ}$, and that above $37^{\circ}$ it increases about 10 times for a rise of one degree. This latter increase may be partly due to the harmful effect of high temperature alone. The minimal bactericidal concentrations were determined with Streptococcus pyogenes incubated in broth, the criteria being clondiness and presence of viable bacteria after 48 hours. 


\section{INCREASED EFFICIENCY OF WEAK ACIDS BY INCREASED ACIDITY}

It has been known for a long time that salicylic and benzoic acids are good antiseptics only in acid solution (see e.g., Cruess and Richert, 1929; Cruess and Irish, 1932). Sulfur dioxide, the standard disinfectant of the yeast industries, has the same property. Recently, propionic acid has been added to this group. Boric acid might also belong in this class, though no records could be found in the literature to bear out this possibility. The effect of $\mathrm{pH}$ on antiseptic efficiency has been ascribed by Bittenbender and associates (1940) to a "specific hydrogen ion effect", while Hoffman, Schweitzer and Dalby (1941) explain it by the "relation of polar and non-polar groups" of the disinfecting acid.

A much simpler explanation has been offered by Rahn and Conn (1944) who assumed that only the undissociated acid acts as antiseptic. In neutral solutions, the acids and their salts are completely dissociated while an increase of acidity produced by the addition of buffers of low pH, such as citric acid and acid phosphates, will decrease the dissociation of the acid in proportion to the dissociation constant. For benzoic acid, this relation is given by the equation

$$
\frac{[\mathrm{H}][\text { Benzoate ions }]}{[\text { undissociated acid }]}=6.6 \times 10^{-5}=\frac{[\mathrm{H}]\lfloor\propto]}{[1-\propto]}
$$

where $\alpha$ represents the "degree of dissociation". The fraction (1- $\alpha$ ), multiplied by the concentration of total benzoic acid gives the concentration of undissociated acid at any $\mathrm{pH}$.

The highest concentration still permitting slow growth, and the lowest concentration preventing growth have been determined by Rahn and Comn (1944) for yeast, 
and are given in Table 32 . The preventive dose varied from $50 \mathrm{mg}$. of sodium benzoate per $100 \mathrm{cc}$. of medium, at pH 3.5 , to over $2,500 \mathrm{mg}$., at $\mathrm{pH} 6.5$. These values, multiplied by $0.847^{1}$, give the amounts of free benzoic acid, and the figures thus obtained multiplied by

TABLE 32

Inhibition of growth of Saccharomyces ellipsoideus by benzoic and salicylic acid. (From Rahn and Conn, 1944. Courtesy of "Industrial and Engineering Chemistry.")

\begin{tabular}{|c|c|c|c|}
\hline \multirow{2}{*}{ pH } & \multirow{2}{*}{$\begin{array}{l}\text { Undissociated } \\
\text { fraction } \\
1-\end{array}$} & \multicolumn{2}{|c|}{ Inhibitory concentration, in mg. per $100 \mathrm{cc}$. } \\
\hline & & $\begin{array}{l}\text { Sodium salt } \\
\text { Growth No growth }\end{array}$ & $\begin{array}{l}\text { Undissociated acid } \\
\text { Growth No growth }\end{array}$ \\
\hline
\end{tabular}

Sodium Benzoate

\begin{tabular}{l|l|rr|rc}
\hline 3.5 & 0.83 & 25 & 50 & 17 & 35 \\
3.65 & 0.77 & 20 & 35 & 13 & 24 \\
4.1 & 0.55 & 40 & 50 & 19 & 23 \\
4.4 & 0.38 & 50 & 100 & 16 & 31 \\
5.0 & 0.13 & 250 & 500 & 28 & 55 \\
5.7 & 0.027 & 250 & 500 & 6.7 & 11.5 \\
5.8 & 0.022 & 1,000 & 1,500 & 19 & 28 \\
6.5 & 0.003 & $\ldots$. & $>2,500$ & $\ldots$. & $>6.4$ \\
\hline
\end{tabular}

Sodium Salicylate

\begin{tabular}{l|l|rr|rr}
\hline 2.93 & 0.527 & 10 & 15 & 4.5 & 6.8 \\
4.10 & 0.070 & 80 & 100 & 4.8 & 6.0 \\
$\mathbf{5 . 1 4}$ & 0.0068 & 600 & 800 & 3.5 & 4.8 \\
$\mathbf{5 . 7 0}$ & 0.00188 & 1,000 & 2,000 & 1.6 & 3.2 \\
\hline
\end{tabular}

the undissociated fraction (1- $\alpha)$, which is characteristic for a given pH, furnish the concentrations of undissociaterl acid. The last column of Table 32 shows that, even with great differences in the amonnt of added benzoate, the amount of undissociated acid remains nearly

1. Ratio of molecular weight of benzoic acid to that of sodium benzoate. 
the same, namely about $25 \mathrm{mg}$. per $100 \mathrm{cc}$. Evidently, yeast ceases to multiply when the undissociated acid reaches a certain concentration.

Salicylic acid has a dissociation constant of $1.06 \times 10^{-3}$, and consequently, its efficiency increases rapidly by a decrease of $\mathrm{pH}$ below 4, while with benzoic acid which is almost completely undissociated at this acidity, the efficiency is changed but little by a further decrease in pII. But the general principle as to the effect of undissociated molecules is the same with both acids as may be seen from Table 32 .

The case of sulfurous acid, which is dibasic and has two dissociation constants, is somewhat different. We have

$$
\frac{[\mathrm{H}]\left[\mathrm{HSO}_{3}\right]}{\left[\mathrm{H}_{2} \mathrm{SO}_{3}\right]}=0.017 \text { and } \frac{[\mathrm{H}]\left[\mathrm{SO}_{3}\right]}{\left[\mathrm{HSO}_{3}\right]}-5 \times 10^{-6}
$$

For each $\mathrm{pH}$ there exist corresponding concentrations of $\mathrm{HSO}_{3}$ ions, of $\mathrm{SO}_{3}$ ions and of undissociated $\mathrm{H}_{2} \mathrm{SO}_{3}$ which are shown in Table 33.

The experiments with Bact. coli showed very consistently that the growth of this organism is inhibited by, a concentration of about $10 \mathrm{mg}$. of $\mathrm{HSO}_{3}$ ions per 100 ec. The growth of yeast, however, was not inhibited by these ions, but only by the undissociated $\mathrm{H}_{2} \mathrm{SO}_{3}$, at concentrations of $0.4 \mathrm{mg}$. per 100 ce., or 4 ppm.

Rahn and Conn measured also the bactericidal efficiency of $\mathrm{H}_{2} \mathrm{SO}_{3}$ and found that it is due exclusively to the undissociated acid. It is remarkable that Bacterium coli, of which the growth is so readily inhibited by $\mathrm{HSO}_{3}$ ions, can tolerate about 10 times as much undissociated acid as yeast.

Propionic acid has recently been used as a fungicide in the food industries. According to Kulman (1940), it is more efficient than formic or acetic acid with yeast, but not with bacteria. Ingle (1940) found the free acid more 
TABLE 33

Inhibition of growth by sodium sulfite. (From Rahn and Conn, 1944. Courtesy of "Industrial and Engineering Chemistry.")

\begin{tabular}{c|c|c|c|c|c|c}
\hline \hline \multirow{2}{*}{$\mathrm{pH}$} & \multicolumn{3}{|c|}{ Fractions of } & $\begin{array}{c}\text { Inhibitory concentration, } \\
\text { in mg. per } 100 \text { cc. }\end{array}$ \\
\cline { 2 - 6 } & $\begin{array}{c}\mathrm{SO}_{3} \\
\text { ions }\end{array}$ & $\begin{array}{c}\mathrm{HSO}_{3} \\
\text { ions }\end{array}$ & $\begin{array}{c}\text { Undiss. } \\
\mathrm{H}_{2} \mathrm{SO}_{3}\end{array}$ & $\mathrm{Na}_{2} \mathrm{SO}_{3}$ & $\mathrm{HSO}_{3}$ ions & $\begin{array}{c}\text { Undissoci- } \\
\text { ated } \\
\mathrm{H}_{2} \mathrm{SO}_{3}\end{array}$ \\
\hline
\end{tabular}

Bacterium coli

\begin{tabular}{l|l|l|l|c|r|r}
\hline $5.9-5.92$ & 0.804 & 0.196 & $10-5$ & $60-80$ & $7.6-10.0$ & 0 \\
6.12 & 0.870 & 0.130 & 0 & $>100$ & $>8.5$ & 0 \\
6.40 & 0.926 & 0.074 & 0 & ca.200 & ca. 9.6 & 0 \\
6.80 & 0.969 & 0.031 & 0 & $>500$ & $>10.0$ & 0 \\
$6.75-7.00$ & 0.968 & 0.032 & 0 & $500-1000$ & $10.4-12.8$ & 0 \\
$7.05-7.25$ & 0.970 & 0.020 & & & & \\
7.6 & 0.975 & 0.019 & 0 & $1000-2000$ & $12.0-18.0$ & 0 \\
$7.6-7.8$ & 0.980 & 0.014 & & & & \\
8.0 & 0.996 & 0.004 & 0 & $>2000$ & $>5.2$ & 0 \\
& 0.998 & 0.0032 & 0 & $2000-5000$ & $5.2-10.5$ & 0 \\
\hline
\end{tabular}

Saccharomyces ellipsoideus

\begin{tabular}{|c|c|c|c|c|c|c|}
\hline 1.0 & 0 & 0.165 & 0.855 & $\cdots \cdot$ & $\cdots$ & $\cdots$ \\
\hline 2.0 & 0 & 0.630 & 0.370 & & .... & \\
\hline 2.48 & 0.001 & 0.836 & 0.163 & $<5$ & $<2.7$ & 0.53 \\
\hline 2.94 & 0.005 & 0.932 & 0.063 & $5-10$ & $3-6$ & $0.21-0.41$ \\
\hline $\begin{array}{lll}4.0 & -4.1\end{array}$ & 0.047 & 0.948 & $\begin{array}{l}0.0056 \\
0.0050\end{array}$ & $100-120$ & $68-74$ & $0,40-0.40$ \\
\hline 4.97 & 0.332 & 0.667 & 0.004 & $1200-1400$ & $518-605$ & $0.32-0.37$ \\
\hline 6.08 & 0.858 & 0.142 & 10 & ca. 1600 & ca.148 & ca. 0.01 \\
\hline
\end{tabular}

efficient than the sodium or calcium salts. Olson and Macy (1940) point out that "the final $\mathrm{pH}$ is an extremely important factor in restraining mold growth". While $2 \%$ sodium propionate had no effect at $\mathrm{pH} 7.0$, it sufficed to prevent mold growth for 5 days at $\mathrm{pH}$ 6.1: These authors advance the theory that inhibition may be due to the undissociater acid. 
This interpretation seems probable as the dissociation constant of propionic acid is $1.3 \times 10^{-5}$. The fractions of undissociated acid are
at $\mathrm{pH} 5$
0.43
at $\mathrm{pH} 6$
at $\mathrm{pH} 7$
.0 .0076
at $\mathrm{pH} S$
0.0007 .

In nentral or alkaline media, the fraction of modissociated acid is so small that even a high concentration of proprionate would give only a very small amount of acid. But when the solution becomes acid, the mdissociated portion increases rapidly from less than $1 \%$ at neutrality to $43 \%$ of the total propionate at $\mathrm{pH} 5$.

A similar effect by the undissociated fraction of an acid has been observed by Rogers and Whittier as early as 1928. They found that the lactic fermentation by Streptococcus lactis ceases, regardless of $\mathrm{pH}$, when the concentration of molissociated lactic acid becomes more than 0.017 molar.

The strong action of the undissociated acids as compared with that of their ions may be explained by the ability of the undissociated molecules to pass through the membrane and through protoplasm "with great rapidity, according to the simple laws of diffusion" while "the permeability of cells to ions is a decidedly complex phenomenon, more or less limited in its extent, and inrolving theoretical equilibria which may be approached rery slowly, and perhaps never be attained" (Jacobs, $1940)$.

Benzoic acid and sulfur dioxide cause an increased lag period as well as a decreased multiplication rate. Figure 31 shows the growth of yeast at pH 4.25 , with increasing amounts of sodium benzoate. The curves with $\mathrm{Na}_{2} \mathrm{SO}_{3}$ are similar.

The length of the lag period and the rate of multiplication depend on pH as well as on the concentration of the 


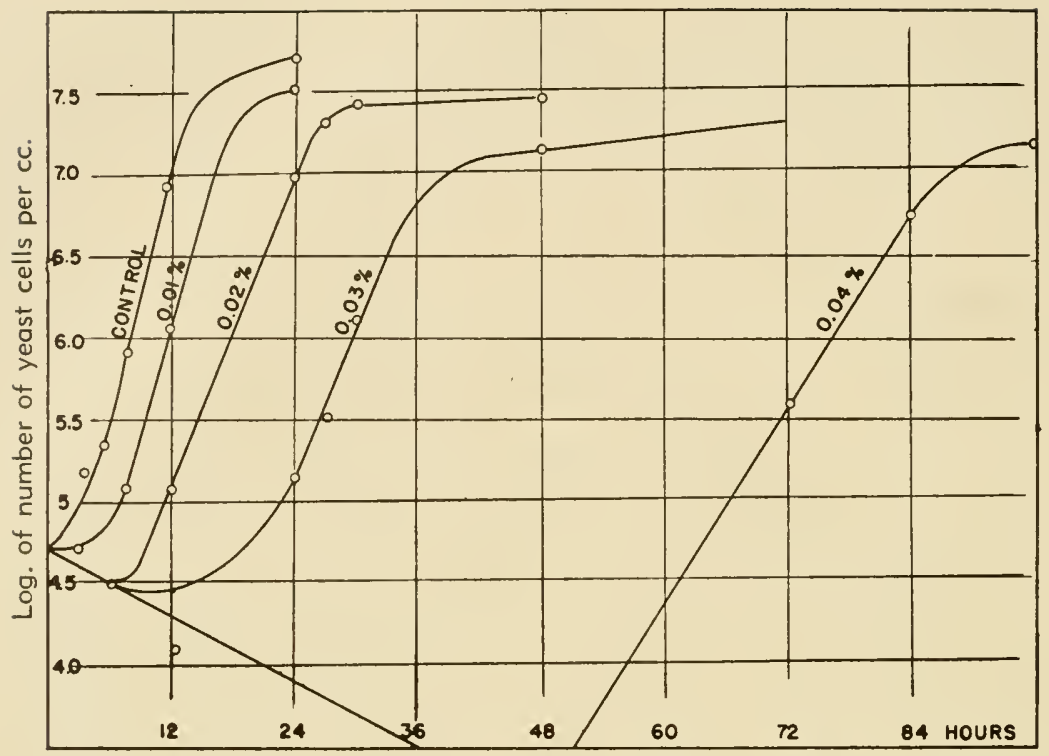

Fig. 31. Multiplication curves of saccharomyres ellipsoirleus treated with various concentrations of benzoic acid, at $\mathrm{pH} 4.1$.

antiseptic. This is shown graphically in Fig 32 which represents the effect of $\mathrm{SO}_{2}$ on Bacterium coli. The concentration of the added $\mathrm{N}_{i_{2}} \mathrm{SO}_{3}$ is plotted logarithmically against the pH. The slanting dotted line is the border line of tolerance. Above this line, the lag period is infinite, and so is the generation time. Just below this line, bacteria require 30 to 140 hour's before growth becones visible, and 2 to 4 times as many hours for doubling their number. The generation times in this figure are only relative values because multiplication was measured by turbidity.

A similar set of data for yeast with benzoic acid (Figure 33) where multiplication had been determined by direct counts and plate counts, represents true generation times. Here also, the lag period as well as the multipljcation rate are greatly affected. The line representing the limit of tolerance has a slope different from that in Figure 32. 


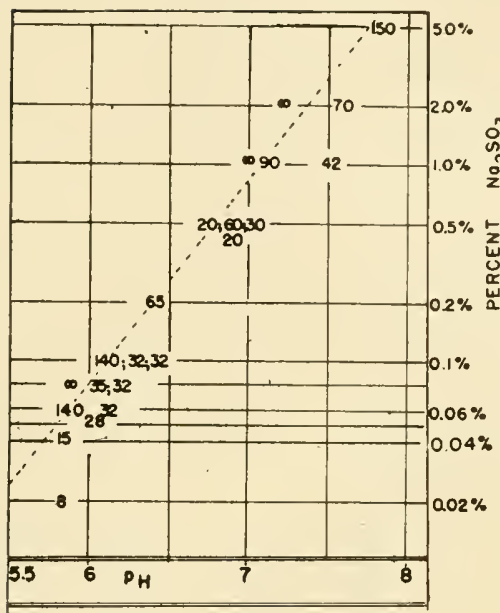

Lag period in hours

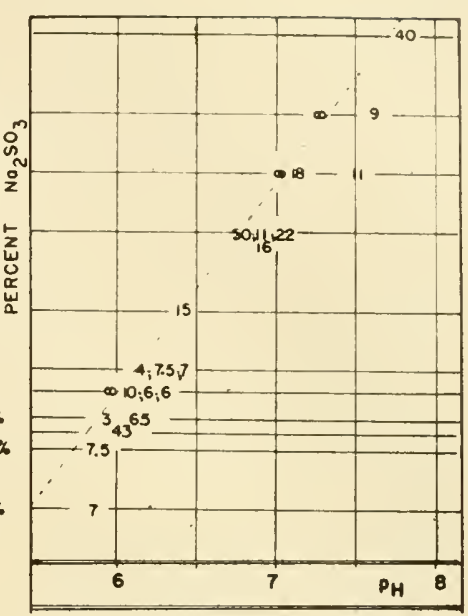

Relative generation time

Fig. 32. Effect of sodium sulfite on the lag period (left), and on the generation time (right) of Bacterium coli at different acidities. The broken line represents the borderline of tolerance, above which the lag period or the multiplication time are infinite and below which they have the values indicated.

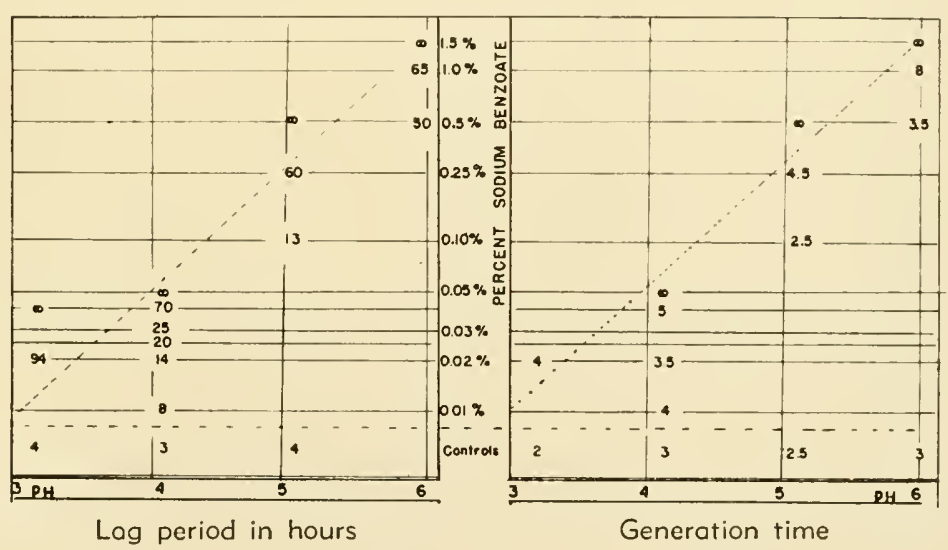

Fig. 33. Effect of sodium benzoate on the lag period (left) and on the generation time (right) of yeast at different acidities. The broken line represents the borderline of tolerance, above which the lag period or the generation time are infinite and below which they have the values indicated. 


\section{ANTAGONISTIC SUBSTANCES FROM MICROORGANISMS}

Just as higher animals are protected against invasion of microorganisms by the secretion of antibodies, lysozymes, and the bactericidal compounds of blood, saliva and milk, so some microorganisms prevent the intrusion of others into their "Lebensraum" by secreting toxic substances. Certain notable antagonisms between different species have been known for a long time. As early as 1887, Garré reported the inhibition of staphylococei and typhoid bacteria by certain fluorescent species. The pyocyanase of Pseudomonas aeruginosa (pyocyanea) has been studied very extensively. In recent years, much attention has been paid to antibiotic substances from microorganisms in the hope that they might be useful in chemotherapy (see review by Waksman, 1941). This hope, however, had to be abandoned in the case of most of these substances because of their toxicity to man. Only gramicidin and penicillin have been retained on the list of the probably useful bacterial products but the search for similar compounds continues.

The long list of organisms which produce substances toxic to other microorganisms includes hyphomycetes, actinomycetes, sporulating and non-sporulating bacteria, but no yeasts and no protozoa. While most groups of microorganisms are represented in this list, there are only a few species in each group.

Concerning the chemical nature of antibiotic agents, much remains to be investigated. There is enough evidence, however, to state that they belong to quite different chemical groups. Dubos (1935) described an enzyme, which dissolves the capsule of pneumococei and is so specific that it attacks only Type III. On the other hand, the substance called pyocyanase, which was assumed to be an enzyme, is probably a lipoid. Gramicidin 
and tyrocidin, two different substances produced by the same Bacillus brevis, have been obtained in crystalline form by Dubos (1939-40) and have molecular weights of about 900 to 1400 but their structure has not yet been determined. The penicillin of Penicillium notatum is so unstable that its structure is also unknown. This substance retains its activity only at low temperatures; however, stable and fairly efficient esters have been obtained (Mệer et al., 1943).

It is not probable that substances so different in nature will act upon bacteria in the same manner. However, little can be said about their mode of action. They cannot be included in any of the groups of antiseptics already discussed because their chemical nature is too uncertain. Most of them are highly selective, as has been stated above for gramicidin and panicillin (they are good antiseptics, but not strong disinfectants). Penicillin will inhibit a few species at a concentration of $1 \mathrm{ppm}$, but others not even at 1000 ppm. (Abraham et ul., 1941) ${ }^{1}$. Table 34 gives some of the data by Waksman and Wood-

TABLE 34

Growth-inhibiting concentrations (in parts per million) of various anti-biotic substances. (From Waksman and Woodruff, 1942.)

\begin{tabular}{|c|c|c|c|c|}
\hline & Bact. coli & B. mycoides & B. subtilis & Sarcina lutea \\
\hline Actinomycin & 300 & 0.1 & 0.03 & 0.3 \\
\hline Streptothricin & 3 & $>300$ & 1 & 30 \\
\hline Tyrothricin* & $>3000$ & 30 & 30 & 10 \\
\hline Gramicidin & $>300$ & $>300$ & $>300$ & 10 \\
\hline Tyrocidin & $>300$ & 3 & 10 & 3 \\
\hline Pyocyanase & $>300$ & 30 & 30 & 30 \\
\hline Pyocyanin & 30 & 10 & 3 & 10 \\
\hline Penicillin & $>300$ & $>300$ & 1 & 1 \\
\hline Gliotoxin & 100 & 10 & 3 & 0.1 \\
\hline Lysozyme & $>100$ & 100 & 3 & 0.1 \\
\hline Phenol & 3000 & 3000 & 1000 & 1000 \\
\hline Sulfanilamide & 1000 & $>1000$ & 100 & 100 \\
\hline
\end{tabular}

*Total active material from Bacillus brevis, containing gramicidin and tyrocidiu.

1. See also p. 12 t. 
luff (1942) concerning the concentrations required for inhibition of growth of fon different organisms.

Staphylococei and streptococei can be adapted to very high doses of penicillin, 30 times the originally inhibiting concentration for the streptococei, 1000 to 6000 times for the staphylococei (Abraham et al., 1941; McKee and Houck, 1943). In this process of adaptation, increase in tolerance was combined with an almost complete loss of virulence. These properties were retained after transfer to normal broth, which is contrary to the usual prompt loss of acquired toleranee. The same retention of penieillin-resistance has been reported by Schmidt and Sesler (1943) for Pneumococcus Type III. There is no relation between resistance to penicillin and to sulfonamides.

The disinfectant action of penicillin has been studied by Hobby, Meyer and Chaffee (1942). The order of death of pneumocoeci, streptococei and staphylococei by $50 \mathrm{ppm}$. of penicillin was logarithmic, at least during the destruction of the first $99 \%$ of the cells (Figure 34 ). The death rate decreased when the size of the inoculum inereased, which may be due to the protective action of large numbers of cells. The penicillin concentration was not noticeably decreased as a result of its bactericidal action. Death was not due to lysis. In a full grown, 18-hourold eulture of Streptococcus hemolyticus, $100 \mathrm{ppm}$. penicillin did not decrease the number of viable eells; but with small inocula, after the bacteria were given a chance to multiply, the same concentration killed almost all the cells at $37^{\circ}$, a smaller number died at $18^{\circ}$, and none at $4^{\circ}$. The deathrate constants were 0.100 and 0.027 , resulting in the very low temperature coefficient $Q_{10}=1.9$.

Remarkable morphological changes are brought about by penicillin, which give a clue in regard to the mode of attack of this drug. Gardner (1940) observed that Clostridium welchii, which is completely inhibited by 17 ppm. penicillin, showed, when treated with as little as 1 ppm. "an extreme elongation of the majority of the cells, 

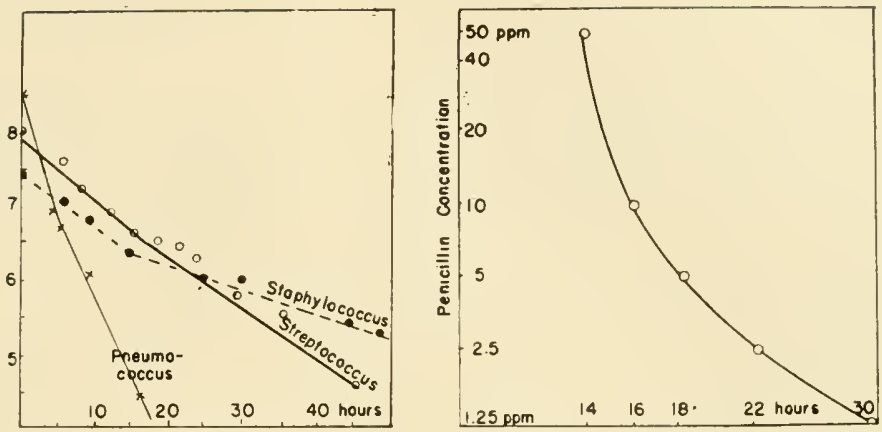

Fig. 34. Left: Death curve of various cocci treated with $50 \mathrm{ppm}$. of penicillin. Abscissa: time in hours; ordinate: logarithm of the number of cells per cc.

Right: Relation between penicillin concentration and death time of Streptoroccus hemolyticus. Abscissa: death time in hour's, on logarithmic scale; ordinate: penicillin concentration, in ppm., on logarithmic scale. (From data of Hobby, Meyer and Chaffee, 1942.)

which took the form of unsegmented filaments ten or more times longer than the average cell." Gram-negative rods also became greatly elongated. Vibrio comma grew into immensely swollen filaments. "With staphylococci, the morphological change takes the form of spherical enlargement of the cell and imperfect fission ... Streptococcus pyogenes showed great swelling of the cells, incomplete fission with formation of large spinoles, and increased length of chain." Gardner concludes: "Growth proceeds, but division and separation do not follow in due course. Many cells then fall victim to autolysis." In the experiments mentioned in Table 35, the present witer observed in the streptococcus cultures giant cells and rod-shaped cells, apparently due to continued g'owth in one dimension without formation of partitions, but litle change was noted in the staphylococcus cultures.

Similar morphological changes have been occasionally reported for other antiseptics, e.g., for methyl violet by Walkel and Murray (1904) and for sulfanilamide by Tumnichiff (1939). But if such effects were the rule with those substances they would have been more frequently reported. 
Gardner's observations remind one of the effect of colchicin upon plant cells.

These morphological effects are in line with the observation by Eagle (1944) that "penicillin impairs the riability of cultured spirochetes, as determined by their failure to grow in subculture, long before their motility has been demonstrably affected. There is at least a hundred-fold disparity between the concentrations of penicillin necessary to immobilize organisms in a given time period, and those which render the organisms nonviable."

Waksman and Woodruff (1942) suggest that our customary media may contain a substance inhibitory to antibiotic action. That would indicate a mode of action similar to that of the sulfomamides. Howerer, the differences of inhibition in synthetic and in other complex nutrient media are so small that they do not offer conrincing proof for this assumption.

Welshimer, Krampitz and Werkman (1944) observed an interference of penicillin with the dismutation of $p y$ -

TABLE 35

Effect of penicillin on the multiplication and final crop of various bacteria. (Original data.)

\begin{tabular}{|c|c|c|c|c|c|}
\hline \multirow{3}{*}{$\begin{array}{l}\text { Penicillin in } \\
\text { glucose broth } \\
\text { (ppm.) }\end{array}$} & \multirow{2}{*}{\multicolumn{3}{|c|}{$\begin{array}{l}\text { Time (in hours) required to } \\
\text { increase the turbidity } \\
10 \text { per cent }\end{array}$}} & \multicolumn{2}{|c|}{$\begin{array}{c}\text { Final crop } \\
\text { (Relative turbidity } \\
\text { values) }\end{array}$} \\
\hline & & & & Large & Small \\
\hline & $\begin{array}{l}\text { Strept. } \\
\text { lactis }\end{array}$ & $\begin{array}{l}\text { Staph. } \\
\text { aureus }\end{array}$ & $\begin{array}{c}\text { Bact. } \\
\text { coli }\end{array}$ & \multicolumn{2}{|c|}{ Streptococcus } \\
\hline $\begin{array}{l}0 \\
1.25 \\
2.5 \\
5 \\
10 \\
15.6 \\
62.5 \\
250\end{array}$ & $\begin{array}{r}0.7 \\
0.8 \\
1.3 \\
8.5 \\
>100^{80}\end{array}$ & $\begin{array}{r}0.8 \\
14.0 \\
\infty\end{array}$ & $\begin{array}{l}0.9 \\
1.0 \\
1.2 \\
0.95 \\
1.1 \\
1.2 \\
1.0 \\
1.0\end{array}$ & $\begin{array}{c}86 \\
72 \\
24 \\
(76) \\
5 \\
0 \\
0 \\
0\end{array}$ & $\begin{array}{c}85 \\
78 \\
29 \\
(81) \\
7 \\
0 \\
0 \\
0\end{array}$ \\
\hline
\end{tabular}


ruvate, but no concentrations are mentioned in their very brief abstract.

The experiences of Gardner and of Eagle mentioned above leave little doubt that the mechanism of cell division is affected by concentrations which interfere neither with growth nor with motility.

Multiplication curves of bacteria in presence of penicillin were studied by the writer who measured neophelometrically the retardation of multiplication with several types of bacteria. No definite increase in the lag period could be observed, and all retardation seemed to be due to a decreased growth rate (Table 35). Streptococcus lactis in presence of $10 \mathrm{ppm}$. penicillin never multiplied enough to increase the turbidity $10 \%$. The final crops show the usual decrease with increasing antiseptic concentration (except with 5 ppm. where multiplication for the first 3 days was in conformity with that of the other cultures, while its velocity increased on the fourth day; the increase could not be traced to a contamination).

From these growth studies, the action of penicillin seems to be identical with that of many antiseptics. Penicillin does not act like a dye nor like a sulfonamide.

The understanding of the nature of the penicillin effect is complicated by the fact that at least two different bactericidal substances are produced by the mold. Besides the true penicillin, a penicillin $B$ has been isolated by Roberts ct al. (1943), while Kocholaty (1942) discorered a substance called penatin, and Coulthard et al. (1942) found an enzrme which they called notatin. This enzyme is an aerobic dehydrogenase oxidizing glueose to gluconic acid with the simultaneous production of $\mathrm{H}_{2} \mathrm{O}_{2}$. Birkinshaw and Raistrick (1943) assume that penicillin $B$, penatin, and notatin are the same substance, which acts simply by gradually accumulating an inhibiting amount of $\mathrm{H}_{2} \mathrm{O}_{2}$. This substance may completely iuhibit multiplication in a dilution of 1 part in a billion, but only when glucose and oxygen are present, and catalase absent. 


\section{SUMMARY AND CONCLUSIONS}

1. The first and immediate effect of toxic substances upon bacteria is an interruption of their multiplication. Reproduction may be only retarded or it may be completely inhibited, depending upon the concentration of the toxic substance. If the concentration is sufficiently low, the cells may not be damaged, the action of the toxic substance on them is reversible, multiplication becoming normal after this substance is removed. Such a reversible inhibition of multiplication, without death, characterizes antisepsis. The condition thus defined is, however, an ideal one, rarely realized; usually a certain amount of slow death accompanies antisepsis. With higher concentration of the toxic substance, another effect is added which characterizes disinfection. The cells lose their reproductive function permanently because of an irreversible reaction of the toxic substance with some cell constituent. Permanent loss of reproductive power is to the bacteriologist equivalent to the death of the cell.

2. The antiseptic action is instantaneous, except with the sulfonamides which permit a fairly normal multiplication for 2 or 3 generations before the toxic effect is noticeable. The disinfectant action is not instantaneous, but proceeds at a measurable rate, called the death rate (the percentage of cells dying during each unit of time).

3. As a rule, the death rate is constant throughout an experiment, and this results in a "logarithmic order of death." In applications to chemical disinfection, the "deathrate constant" is a valuable tool for the study of the fundamental lethal reaction.

4. A constant death rate indicates that death is caused by the reaction of one single molecule of the cell with the 
disinfectant. It seems logical to assume that this allimportant molecule is either a gene or a similar mastermolecule of the cell division mechanism. Several authors have defined the death of bacteria as a lethal mutation. In the outstanding exceptional case of chlorine, for which the order of death is not logarithmic, it is probable from microscopic observation that the cell membrane is attacked first, and that many membrane molecules must be destroyed before the cell is dead.

5. Constant death rates permit us to express the effects of temperature and of concentration in simple terms. The death rate increases with increasing temperature, and, as a rule, the temperature coafficient for 10 degrees $\mathrm{C}$. is between 3 and 5 .

6. The efficiency of disinfectants increases with their concentration, but not in the same manner for all disinfectants. With formaldehyde, hydrogen peroxide and many other disinfectants, the deathrate constant is approximately proportional to the concentration, but with some other's, it is proportional to the square of the concentration, or to the square root, and with the phenols it increases as the 6th to 8th power of the concentration.

7. The only standard method for the evaluation of disinfectants is the phenol coefficient which states how many times as powerful as phenol a disinfectant is. As the efficiency of phenol changes with the concentration in an exceptional manner, different from that of practically all other antiseptics, this ratio varies greatly when dilute concentrations are compared. The choice of phenol as a standard is therefore most mufortunate. The range allowed by the Federal Drug Administration Method gires values with a calculated permissible deriation of 260\%. A new method is proposed here which gives the death times for any concentration of the disinfectant directly, not merely in comparison with phenol. By this method, the interference of orginic matter with disinfection can also be measured quantitatively. 
8. The efficiency of antiseptics cimmot be studied by the technique used with disinfectants. As the reaction of antiseptics is instantaneous, no rate of reaction can be computed, and the mode of action can be ascertained only by observing the effects of weaker doses which retard, but do not stop multiplication. No temperature coefficient and no concentration exponent can be established for antiseptics.

9. Antiseptics retard multiplication in two quite different ways; they may decrease the multiplication rate, or they may increase the lag period, i.c., the time normally required by transferred cells to adjust themselves to the new environment, or to change from the senile to the juvenile state. Dilute phenol, penicillin, and sulfonanides decrease the reproduction rate withont affecting the lag period. Dyes extend the lag period, eventually to several days, without reducing the rate of reproduction, if multiplication starts at all. Formaldehyde, sulfur dioxide and benzoic acid prolong the lag phase and also reduce the rate of multiplication.

10. As was said above, the lethal reaction of most disinfectants is a reaction with some molecule without which cell division cammot take place. It seems certain that this molecule must be of protein nature. No other single molecule can be so important. The compounds cansing death belong to a great variety of ehemical groups, and do not react in the same way with proteins. But a native protein has many very different sidechains, and the inactivation of any one of these may be sufficient to terminate its physiological function. Thus the fundamental lethal reaction of different disinfectants may not be identically the same, but it represents an attack on the same molecule, or group of molecules. Exceptions must be expected. Chlorine has alleady been mentioned as attacking first the cell nembrane. It is imaginable that some compounds dastroy the enzymes more readily than the synthesis or multiplication mechanisms, though all evi- 
dence, so far, has shown that enzymes react more slowly than the reproduction mechanisms.

11. Growth retardation by antiseptics is not always due to the same reaction. Here too, as a rule, the enzymes suffer less than the mechanisms of synthesis and cell division. But there is more variety in the mode of attack than with disinfectants. The most common effect is a decrease of the growth rate, probably from partial inactivation of the catalysts which bring about synthesis. The sulfonamides are different from all other antiseptics, for they do not affect resting cells. They interfere only with the third or fourth generation of growing cells, and the interference can be avoided completely by addition of p-amino benzoic acid. This suggests that growth is not inhibited because the sulfonamide reacts with some essential cell protein, but because it becomes part of the cell structure which then fails to function.

12. The retardation by dyes is quite certainly due to an abnormal oxidation-reduction potential, and if the cells are present in sufficient numbers, they can readjust the potential and can then multiply completely unrestricted.

13. An investigation of the relation between the acidity and the antiseptic power of organic acids and sulfur dioxide has shown that the undissociated acid molecules are the real inhibitory factor, probably because they get into the cell more readily than the ions.

14. The picture of death and of growth inhibition is by no means perfectly clear, and it cannot be clear as long as we have no perfect understanding of the mechanisms upon which life depends. But by virying the condition of death, by varying the species under test, and by applying quantitative metlods, our conceptions of the death of the cell are becoming more definite, and ultimately this study will not only explain the mechanism of death, but will permit important conclusions about the unknown mechanism of life. 


\section{BIBLIOGRAPHY}

ABRAHAM, E. P., E. CHAIN, C. M. FLETCHER, A. D. GARDNER, N. G. HEATLY, M. A. JENNINGS and H. W. FLOREY, Lancet, $241,177,1941$.

ANDERSON, L. P. and W. L. MALLMANN, Mich. State College Tech. Bull., 183, 1943.

BAKER, Z., R. W. HARRISON and B. F. MILLER, J. Exp. Med., 7 , 249,$1941 ; \% 4,611$ and $621,1942$.

BARRON, E. S. G. and H. R. JACOBS, Proc. Soc. Exp. Biol. and Med., $37,10,1937$.

BEAMER, P. R. and F. W. TANNER, Zb7. f. Baht., II, 100, 81, 1939a; $100,202,1939 \mathrm{~b}$.

BECHHOLD, H., Ztschr. f. Electrochem., 2., 147, 1918.

BELEHRADEK, J., Temperature and Living Matter, Berlin, 1935.

BELL, P. H. and R. O. ROBLIN, J. Am. Chem. Soc., 64, 2905, 1942.

BIRKHAUG, K. E., J. Infect. Dis., 53, 250, 1933.

BIRKINSHAW, J. H. and H. RAISTRICK, J. Biol. Chem., 1/4, 459, 1943.

BITTENBENDER, W. A., E. F. DEGERING, P. A. TETRAULT, C. F. FEASLY and B. H. GWYNN, Ind. and Eng. Chem., 32, 996, 1940.

BORMAN, E. K., J. Buct., 2.3, 315, 1932.

BOYCOTT, A. E., J. Path. and Bact.. 2.3. 237, 1920.

BRONFENBRENNER, J., A. D. HERShEY and J. A. DOUBLY, Proc. Soc. Exp. Biol. and Med., 38, 210, 1938.

CAMERON, E. J., J. Bact., 19, 52, 1930.

CHARLTON, D. and M. LEVINE, Iowa State College Engineering Exp. Sta. Bull., 132, 1937.

CHICK, H., J. Hyg., S, 92, 1908; 10, 237, 1910.

and C. J. MARTIN, J. Hyg., \&, 654, 1908.

CHU, H. I. and A. B. HASTINGS, J. Pharmacol., 63, 407, 1938.

CHURCHMAN, J. W., J. Exp. Med., 16, 221, 1912.

CLARK, H. W. and S. de M. GAGE, 3ith Ann. Report, state Board of Heulth Massuchusetts, p. 245, 1903.

COHEN, B., J. Bact.; $\gamma, 1 \delta 3,1922$.

COOPER, E. A. and J. MASON, J. Hyg., 26, 118, 1927.

\section{, J. Path. and Bact., 31, 343, 1928.}

COULTHARD, E. E., R. MICHAELIS, W. F. SHORT, G. SYKES, G. E. H. SKRIMSHIRE, A. F. B. STANDFAST, J. H. BIRKINSHAW and H. RAISTRICK, Nature, 150, 634, 1942.

CRUESS, W. V. and J. H. IRISH, J. Bact., 23, 163, 1932. and P. H. RICHERT, J. Bact., 1\%, 363, 1929.

CURRAN, H. R., F. R. EVANS and A. LEVITON, J. Bact., 40, 423, 1940.

DAVEY, W. P., J. Exp. Zool., 22, 573, 1917.

DIERNHOFER, K., Ztschr. Fleisch und Milch Hygiene, 43, 328, 1933. Milchw. Forschungen, 18, 83, 1936.

DITTMAR, H. R., I. L. BALDWIN and S. B. MILLER, J. Bact., 19, 203,1930 . 
DORFMAN, A., L. RICE, S. A. KOSER and F. SAUNDERS, Proc. Soc. Exp. Biol. and Med., 45, 750, 1940. and S. A. KOSER, J. Infect. Dis., r1, 241, 1942.

Downs, C. M., J. Bact., 44, 392, 1942.

DUBOS, R., J. Exp. Med., 49, 575, 1929; 62, 259, 1935; 70, 1, 1939. and R. D. HOTCHKISS, J. Exp. Med., 73, 629, 1941.

EAGLE, H., J. Bact., 4\%, 427, 1944.

EGGERTH, A. H., J. Exp. Med., 46, 671, 1927; 49, 53, 1929; 50, 299, 1930 ; $53,27,1931$.

EIJKMAN, C., Versl. Kon. Akad. Wetenschappen Amsterdam, Wis-en Natuurkunde, 21 (I), 507, 1912.

ELY, J. O., J. Bact., 38, 391, 1939.

ESTY, J. R. and K. F. MEYER, J. Infect. Dis., 31, 650, 1922.

FILDES, P., British J. Exp. Path., 21, 67, 1940.

FOTER, M. J. and O. RAHN, J. Bact., 32, 485, 1936.

FOX, C. J. and H. M. ROSE, Proc. Soc. Exp. Biol. and Med., 50, $142,1942$.

FRICKE, H. and M. DEMEREC, Proc. Nat. Acad. Science, 320, 1937.

GAGE, S.de M. and G. STOUGHTON, science, 23, 216, 1906.

GARDNER, A. D., Nature, 1/46, $837,1940$.

GARRÉ, C., Zbl. f. Bakt., 2, 312, 1887.

GATES, F. L., J. Gen. Physiol., 13, 231, 1929.

GEGENBAUER, V., Archiv f. Hygiene, 90, 23, 1921.

GREIG, M. E. and J. C. HoOGERHEIDE, J. Bact., 41, 557, 1941.

GROVES, J. F., Bot. Gazette, 63, 169, 1917.

HARTMANN, G., Milchw. Forschungen, 18, 116, 1936.

HARVEY, H. W., Ann. Bot., 23, 181, 1909.

HASTINGS, E. G., E. B. FRED and W. R. CARROLL, Zbl. f. Bakt., II, $6 \%, 162,1926$.

HENRY, R. J., Bact. Reviews, \%, 176, 1943.

HEWLETT, R. T., Lancet, 741, 1909 (I).

HIRSCH, J., Compt. rend. Soc. Turque, sciences Physiques et Naturelles, $10,19,1942$

HobBy, G. L., K. MEYER and E. CHAFFEE, Proc. Soc. Exp. Biol. and Med., 50, 281, 1942.

HOFFMAN, C., T. R. SCHWEITZER and G. DALBY, Ind. and Eng. Chem., 33, 749, 1941.

HOFFMANN, C. E., Thesis, Cornell University, 1943.

and O. RAHN, J. Bact., 47, 177, 1944.

HOLWERDA, B. J., Mededeelingen van den Dienst der Volksgeuzondheid in Ned. Indie, 1\%, 251, 1928; 19, 326, 1930. (Quoted from Charlton and Levine, 1937)

INGLE, J. D., J. Dairy Science, 23, 509, 1940.

INGRAHAM, M. A., J. Bact., 26, 573, 1933.

ISAACS. M. L., In F. P. Gay, Agents of Disease and Host Resistance, p. $228,1935$.

JACOBS, M. H., Cold Spring Harbor Symposia, 8, 30, 1940.

JOHNSON, F. H., Science, 95, 104, 1942. 323,1941 . 
JOHNSON, J. R., W. F. BRUCE and M. A. DUTCHER, J. Am. Chem. Soc., $65,2005,1943$.

KATZIN, L. I. and L. A. SANDHOLZER, J. Bact., 41, 722, 1942.

KLARMANN, E., Soap, 9, Dec. 1933.

1941.

KNAYSI, G., J. Infect. Dis., fi, 293, 303, 318, 322, and 328, 1930.

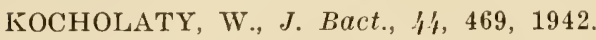

KOHN, H. I. and J. S. HARRIS, J. Pharmacol., $73,343,1941 ; \% 3,383$, $1941 \mathrm{a}$. J. Bact., 41, 717, 1942.

KRAUSE, G. A. and J. F. BERGMANN, Nene Wege zur Wassersterilisierung ( $Y$ atadyn). München, 1928.

KRöNIG, B. and TH. PAUL, Ztschr. f. Hygiene, 2.5, 1, 1897.

KULMAN, J., Chem. Listy, 33, 420, 1939. (Quoted from Chem. Abstracts, No. 5471, 1940.)

KUMILER, W. D. and T. C. DANIELS, J. Am. Chem. Soc., 65, 2190, 1943.

LAMIANNA, C. and I. M. SHAPIRO, J. Bact., 45, 385, 1943.

LANDY, M., N. W. LARKUM, E. J. OSWALD and F. STREIGHTOFF, Science, $9 \%, 265,1943$.

LANGE, B., Ztschr. f. Hygiene, 96, 92, 1922.

LEE, R. E. and C. A. GILBER'T, J. Phys. Chem., 22, 348, 1918.

LEE, S. W., J. A. EPSTEIN and E. J. FOLEY, Proc. Soc. Exp. Biol. and Med., 5\%, 107, 1943.

LEONARD, G. F., J. Infect. Dis., 4S, 359, 1931.

LlOYD, L., Ann. Applied Biol., $\gamma, 66,1920$.

LOEB, J. and J. H. NORTHROP, J. Biol. Chem., 32, 103, 1917.

LOMMEL, J., Compt. Rend. Soc. Biol., 95, 714, 1926.

MacLEOD, C. M., Proc. Soc. Exp. Biol. and Med., 41, 215, 1939.

and G. S. MIRICK, J. Bact., 4h, 277, 1942.

MADSEN, T. and M. NYMAN, Ztschr. f. Hygiene, 5\%, 388, 1907.

MAGOON, C. A., J. Bact. 11, 253, 1926.

MALLMANN, W. L. and W. B. ARDREY, Mich. State College, Eng. Exp. Sta. Bull., 91, 1940.

MeCULLOCH, E. C., Disinfection and Sterilization. Philadelphia, 1936.

McIlWAIN, H., Brit. J. Exp. Path.. 21, 136, 1940.

$\longrightarrow$, Lancet, 412, 1942 (I).

McINTOSH, J. and L. E. H. WHITBY, Lancet, 431, 1939 (I).

McKEE, C. M. and C. L. HOUCK, Proc. Soc. Exp. Biol. and Med., 5s, $33,1943$.

MEADER, P. D. and W. A. FEIRER, J. Infect. Dis., 39, 237, 1926.

MELLON, R. R. and L. L. BAMBAS, Proc. Soc. Exp. Biol. and Med., $36,682,1937$.

MEYER, K., G. L. HOBBY and E. CHAFFEE, Science, 97, 205, 1943. Med., 53, 100, 1943.

Miller, B. F., R. Abrams, D. A. HUBER and M. KLEIN, Proc. Soc. Exp. Biol. and Med., 54, 174, 1943. 
MUIR, R. D., V. J. SHAMLEFFER and L. R. JONES, J. Bact., 价, $95,1942$.

MúlLLER, A., Archiv f. Hygiene, 89, 363, 1920.

II YERS, R. P., J. Bact., 15, 391, 1928. , J. Agr. Research, 38, 521, 1929.

O'KANE, W. C., W. A. WESTGATE and L. C. GLOVER, New Hampshire Agr. Exp. Station Tech. Bull., 5\&, 1934.

OLSON, J. C. and H. MACY, J. Dairy Science, 23, 509, 1940.

PAUL, T., Biochem. Ztschr., 1s, 1, 1909.

PAUL, TH., G. BIRSTEIN and A. REUSS, Biochem. Ztschr., 29, 202 and $249,1910$.

PENFOLD, W. J., Proc. Roy. soc. Med., h, 97, 1911.

PETERs, R. A., J. Physiol., 5\%. 260, 1920.

PHELPS, E. B., J. Infect. Dis., 8, 27, 1911.

RAHN, O., J. Gen. Physiol., 13, 179, 1929; 13, 395, 1930; 1', 315, 1931.

, Physiology of Bacteria, Philadelphia, Blakiston, 1932.

, Cold Spring Harbor Symposia on Quantit. Biol., 2, 70, 1934. and M. N. BARNES, J. Gen. Physiol., 16, 579, 1933.

and F. M. BIGWOOD, Arch. f. Hikrobiol., 10, 1, 1939.

and J. E. CONN, Ind. and Eng. Chem., 36, 185, 1944.

RALsTON, A. W. and C. W. HOERR, J. Organic Chem., 7, 546, 1942. REICHEL, H., Biochem. Ztschr., 22, 149, 1909.

REICHENBACH, H., Ztschr. f. Hygiene, 69, 171, 1911.

REVIS, C., Proc. Roy. Soc., B, 85, 192, 1912.

RIDEAL, S. and J. T. A. WALKER, J. Roy. San. Inst., 24, 421, 1903.

ROBERTS, E. C., C. K. KAIN, R. D MUIR, F J. REITHEL, W. L. GABY, J. T. VAN BRUGGEN, D. M. HOMAN, P. A. KATZMAN,

L. R. JONES and E. A. DOISY, J. Biol. Chem., 14\%, 47, 1943.

ROGERS, L. A. and E. O. WHITTIER, J. Bact., 16, 211, 1928.

SATTLER, W., Nilchwirtsch. Forschungèn, $\tau$, 100, 1928.

SCHAFFER, J. M. and F. W. TILLEY, J. Infect. Dis., 3\%, 359, 1925.

SCHMIDT, L. H. and C. L. SESLER, Proc. Soc. Exp. Biol. and Med., $52,353,1943$.

SEVAG, M. G. and M. SHelbuRNE, J. Bact., 43, 411, 421 and 447, 1942.

SHERMAN, J. M. and W. R. ALBUS, J. Bact., \&, 127, 1923.

SLANETZ, L. W. and L. F. RETTGER, J. Bact., 26, 599, 1933.

SMITH, J. HENDERSON, Amn. Applied Biol.. \&, 27, 1921; 10, 335, 1923.

SNELL, E. E. and H. K. MITCHELL, Arch. of Biochem., 1, 93, 1943.

STARKEY, R. L. and S. A. WAKSMAN, J. Bact., 45, 509, 1943.

STEARN, A. E. and E. W. STEARN, J. Bact., 9, 491, 1924; 11, 345, 1926.

STEINBERG, R. A., Bot. Gazette, 9\%, 666, 1936.

THOM, C. and R. A. STEINBERG, Proc. Nat. Acad. Science, 25, 329, 1939.

THOMAS, R. C., Ohio Agr. Exp. Sta. Tech. Bull., 10, 1932.

TILLEY, F. W., J. Bact., 38, 499, 1939; 43, 521, 1942. 
TILLEY, F. W., and R. M. CHAPIN, J. Bact., 19, 295, 1930. and J. M. SCHAFFER, J. Infect. Dis., 3\%, 359, 1925.

TUNNICLIFF, E. A., J. Infect. Dis., 64, 59, 1939.

WAKSMAN, S. A., Bact. Reviews, 5, 231, 1941. and H. B. WOODRUFF, J. Bact., 44, 373, 1942.

WALKER, J. E., J. Infect. Dis., 35, 557, 1924; 3\%, 181, 1925.

WALKER, J. T. A. and R. S. MURRAY, Brit. Med. J., 2, 16, 1904.

WATKINS, J. H., Thesis. Yale University, 1932. and C. E. A. WINSLOW, J. Bact., 2', 243, 1932.

WATSON, H. E., J. Hyg., 8, 536, 1908.

WELSHIMER, H. J., L. O. KRAMPITZ and C. H. WERKMAN, J. Bact., $45,425,1944$.

WHITE, H. J., J. Bact., 38, 549, 1939.

WINSLOW, C. E. A. and O. R. BROOKE, J. Bact., 13, 235, 1927.

WINSLOW, C. E. A. and I. S. FALK, J. Bact., 11, 1, 1926.

WOODS, D. D., Brit. J. Exp. Path., 21, 74, 1940.

WYCKOFF, R. W. G., J. Exp. Med., 52, 435, 1930.

- - — and T. M. RIVERS, J. Exp. Med., 51, 930, 1930.

WYSS, O., F. B. STRANDKOV and F. C. SCHMELKES, Science, 96, $236,1942$.

ZEUG, M., Archiv f. Hygiene, S9, 175, 1920. 


\section{SUBJECT INDEX}

Acids, disinfection by, $76, \$ 2,84$ Adaptation to poisons, 58

Age of cells, effect on death, 42, 141

Alcohols, concentration exponents of, 73,89 ; disinfection by, 89

Algae, death of, 51

Alkalies, disinfection by, 85, 108

Antagonists to sulfonamides, 153

Antibiotics, 164

Antidotes, 82, 86

Antiseptics, definition of, 62, 63 , 119 ; effect of age of cells on action of, 141; effect of concentration of, $120,132,141,148$; effect of cell concentration on, 133 , 143; effect of temperature on. 121; evaluation of, 118,120 ; mode of action of, 130,138 ; selectivity of, 123

Argyn, argylol, SS

Aspergillus. death of spores of, 51

Bacteriostasis, 137

Benzoic acid, 157, 162

Cell concentration, and antisepsis, 133, 143; and death time, 54

Cell mechanisms, 9, 10, 11

Chemotherapy, 83

Chlamydomomas, death of, 51, 52

Chlorine, efficiency of, $\$ 0, \$ 2,92$; disinfection, abnormal order of death in, 51, 53

Colloidal metals, SS, 89

Colpidium, death of, 51,52

Concentration exponents, 66. 73 , 102; meaning of, 70

Copper salts, $8 S, 89$

Crop decrease by antiseptics, 121 , 129,169

Crystal violet, 127 , $13 \mathrm{~s}$

Dead cells protecting living cells, 5s

Death, a mutation, 41; by heat, 14 . 15, 18; by X-rays, 14, 15, 18: cause of, 28,31 ; dennition of, 9 , 40; non-logarithmic ordel of. 42; order of, $13,2 S, 31$; ordler of, when vely slow, $4 i$
Deathrate constant, 29, 30

Deathtime, 30

Decimal reduction time, 30

Detergents, 99

Disinfectants, as antiseptics, 12S, 132; concentration exponents of, 66 ; definition of. $62,63,119$; efficiency of, 101. 109; interfer. ence by foreign matter, 80; selectivity of, 65 ; standardization of, 101,109 ; temperature coefficients of, 74

Dormancy at low temperature, ig Drug-fastness by adaptation, 58

Dyes, 136 ; selective action of, 65

Enzymes, inactivation of, as cause of death, 36 seq. : inactivation by sulfonamides, 149; molecules per cell. 37

Evaluation of antiseptics, 11S, 120; of disinfectants. 101, 109

Fatty acids, $9 \mathrm{~s}$

Ferleral Drug Administration method, 103

Flour beetle, death of, 14, $1 \mathrm{~s}$

Formaldehyde, as antiseptic, 130; as disinfectant, 90,106, 112, 129

Fruitflies, death by heat, $1 \mathrm{~s}$

Genes affecterl chemically, 41

Gentian violet, 127,138

Gliotoxin, 165

Graded resistance, 25, 31, 35, 36, 45,56

Gram stain. and antisepsis, 123; and disinfection, 64

Gramicidine. 124, 165

Growth retardation by antiseptics, 150,163

Halogens, 92

Hands, disinfection of, 96, 100

Hydlogen ions as disinfectants, $76,82,84$

Hyarogen peroxide. \$3, \$9. 91. 106. 112

Inactivation, of enzymes, 36 ; of genes, 10 
Inhibition, irreversible, 62; permanent, 62 ; revel'sible, 62 ; temporary, 62

Inoculum, affecting antisepsis, 133, 143, and deathtime, 54

lodine, 95

Katadyn, 89

Lag, extension by antiseptics, 162; phase, prolonged by antiseptics, $130,138,143$

Majority thermal cleath point, 46

Nass law and disinfection, 37

Mercuric chloride, $\$ 5,86,102,113$; concentration exponent of, $67,7 t$

Mercurochrome, 87, 106

Mercury compounds, 85

Metals as disinfectants, 89

Metaphen, 87, 106

Methionine antagonizing sulfonamides, 156

Mold spores, death of, 50

Mortality curves, 13, 15, 22, 24, 26

Mosquitoes, death of, 14, 34

Nulticellular $v s$. unicellular organisms, 20, 24

Multiplication retarded by antiseptics, 130

Mustard seeds, death by poison, 18,34

Mutations, 41

Non-logarithmic order of death, 42

Olygodynamic action, 88

Organic matter, disturbing disinfection, 80,84 ; measure of influence, 111

Oxidation-reduction potential, 139. 142

p-amino benzoic acid, 153

Penicillin, 165; causing morphological changes, 166 ; selectivity of, 126

Pelmanganate, 91, 106, 112

$\mathrm{pH}$ affecting antisepsis, 140, 14t, 154,157

Fhenol, as antiseptic, 120; coefficients, 101, 106, 111; concentration exponent of, 68 , 73 ; disinfection by, $90,106,112$
Fhysiological youth, 141

Propionic acid, 159

Protozoa, death of, 51, 52

Purines antagonizing sulfonamicles, 156

Pyocyanin, 164, 165

Resistance, abnormal, of inclividuals, $45,46,57$

Resistant strains, 56

Rivanol, 137, 139

Salicylic acid, 158

Selection of resistant strains, 56

Selective culture media, $12 \mathrm{~S}$

Selectivity, of antiseptics, 65, 123; of disinfectants, 63

Silver, colloiclal, 88 ; nitrate, concentration exponent of, 69 ; salts, s8, 106,112

Slow death, order of, 47

Soaps, 64, 66, 95

Sodium azide, selectivity of, 124

Specificity, see selectivity

Standardization of disinfectants, 64. 101, 109

Sterility, a lethal mutation, 41

Suliathiazole, 139

Sulfonamides, 146; ionization of, 155

Sulfonated niacin, 154

Sulfur dioxide, 159, 163

Survivor curves, 13, 15, 24

Tadpoles, death of, 14, 21, 25, 34

Technique of evaluating disinfectants, $101,109,116$

Temperature, and antisepsis, 121; and sulfonamides, 156 ; coefficients of disinfection, 76 ; coefticients of life and leath, 78; effect on disinfection, 74

Thickness of cell membrane, 35

Tcmato moth larvae, deathrate of, 34

Toxicity index, 109

Tribolium, death by X-rays, 14, 18

Tubercle bacteria, resistance of, 64

Wetting agents, 99

Wheat seeds, death by heat, 34

Yeasts, death of, $14,15,34,48,50$ 


\section{AUTHOR INDEX}

Abraham, 126, 165

Abrams, 100

Albus, 42

Anderson, 93

Ardrey, 53, 93, 94

Baker, 100

Baldwin, 89, 91

Bambas, 149

Barnes, 50, 73

Barron, 149

Beamer, 14, 20, 36, 46, 50

Bechhold, 59

Belehradek, 79

Bell, 155

Bergmann, 89

Bigwood, 79

Birkhaug, 131, 132

Birkinshaw, 169

Birstein, 68, 72, 75

Bittenbender, 157

Borman, 58

Boycott, 14, 36

Bronfenbremner, 109

Brooke, 116

Cameron, 122

Carroll, 57

Chaffee, 166

Chain, 126, 165

Chapin, 92

Charlton, 53, 75, 93, 95

Chick, 13, 18, 36, 43, 67, 72, 7374 $75,76,78,81,101,102$

Chu, 149

Churchman, 137

Clark, 18

Cohen, 75,76

Conn, 129, 132, 157, 160

Cooper, 127

Coulthard, 169

Cruess, 122, 135, 157

Curran, 83

Daddi, 151

Dalby, 157
Daniels, 155

Davy, 18

Dawson, 165

Degering. 157

Demerec, 40

Diernhofer, 123

Dittmar, 89, 91

Doisy, 169

Dorfman, 150

Doubly, 109

Downs, 126

Dubos, 124, 138, 140, 144, 164, 165

Eagle, 168

Eggerth, 97, 98

Eijkman, 50

Ely, 109, 152

Epstein, 135, 137

Esty, 55

Evans, S3

Feasly, 157

Fildes, 153

Fletcher, 126, 165

Florey, 126, 165

Foley, 135, 137

Foter, 79, 152

Fox, 154

Fred, 57

Fricke, 40

Gaby, 169

Gage, 18, 46, 56

Gardner, 126, 165, 166

Garré, 164

Gates, 57

Gegenbauer, 26, 73, 74, 86, 120

Gilbert, 34, 36

Glover, 14, 34

Greig, 151

Groves, 34

Gwymn, 157

Haldane, 37

Hand, 37

Harris, 147, 148, 150, 156 
Harrison, 100

Hartmamn, 123

Harvey, 51

Hastings, A. B., 149

Hastings, E. G., 57

Heatly, 126, 16 כ

Henry, 146

Hershey, 109

Hewlett, 18, 34

Hirsch, 139, 150

Hobby, 165, 166

Hoel'l', 99

Hoffman, 157

Hoffmann, 138, 141-144

Holwerda, 92

Homan, 169

Hoogerheide, 151

Hotchkiss, 124

Honck, 166

Huber, 100

Ingle, 159

Ingraham, 127, 13S, 142

Irish, 157

Isaacs, 36

Jacolss, H. R., 149

Jacolss, M. H., 161

Jennings, 126, 165

Johnson, 147, 154

Jones, 146, 169

Kain, 169

Katzin, 30

Katzman, 169

Klarman, 96, 97, 9s

Klein, 100

Knaysi, 31, 47

Kocholaty, 169

Kohn, 147, 148, 150, 156

Krampitz, 168

Krause, 89

Klönig, 66, 69, \&4, 85

Kulman, 169

Kumler, 155

Lamanna, 156

Landy, 153

Lange, 58

Larkum, 153
Lee, R. E., 34, 36

Lee, S. W., 135, 137

Leonar.d, SS

Levine, 53, 75, 93, 95

Leviton, $\$ 3$

Lloyd, 34

Loeb, 1S, 31, 34

Lommel, 41

MacLeod, 133, 151

Macy, 160

Madsen, 13, 34, 75

Magoon, 57

Mallmann, 53, 93, 94

Martin, $81,101,102$

Mason, 127

McCullough, 64, 76, 7 $8,84,106,122$

MeIlwain, 154

llcintosh, 152

McKee, 166

Meader, $5 \mathrm{~S}$

Mellon, 149

Meyer, 55, 165, 166

Michaelis, 169

Willer, B. F., 100

Miller, S. B., \$9, 91

Mirik, 133

Mitchell, 156

Moore, $14 \overline{7}$

Inir, 146, 169

Miiller, 74

Mul'ay, 167

Myers, 34, 85

Northrup, 1S, 31, 34

Nyman, 13, 75

O'Kane, 14, 34

Olson, 160

Oswald, 153

Paul, 38, 66, 68, 69, 72, 75, 84,85

Penfold, 41

Peter's, 51

Phelps, 101, 102

Rahn, 20, 40, 42, 57, 79, 13s, 142, 148

Raistrick, 169

Ralston, 99 
Reichel, 73, 90

Reichenbach, $34,85,45$

Feithel, 169

Rettger, 142

Reuss, 68, 72, 75

Revis, 41

Rice, 150

Richert, $122,135,157$

Rideal, 101

Roberts, 169

Roblin, 155

Rogers, 161

Rose, 154

Sandholzer, 30

Sattler, 34

Saunders, 150

Schaffer; 97

Schmidt, 166

Schweitzer', 157

Sesler, 166

Sevag, 151

Shamleffer, 146

Shapiro, 156

Shelburne, 151

Sherman, 42

Short, 169

Shternow, 96, 97

Skrimshire, 169

Slanetz, 142

Smelkes, 152

Smith, J. H., 35, 50, 75

Snell. 156

Standfast, 169
Starkey, 85

Stearn, 138, 145

Steinberg, 41

Strandiov, 152

Sykes, 169

Tanner, 14, 20, 36, 46, 50

Tetrault, 157

Thom, 41

Thomas, 106

Tilley, 71-76, \$9, 92, 97

Tunicliff, 167

van Bruggen, 169

Waksma $1,55,165$

Walker, J. E., 9t;

Walker, J. T. A., 16 i

Watkins, 1S, 20, 33, 59, 108

Watson, 67. 70, 72, 101

Trelshimer, 1 es

Terkman, 168

Westgate, 14,34

Whitby, 152

White. 156

Whittier, 161

Winslow, 20, 33, 34, 59, 116

Woelz, 47, 50

IVoods, 153

Toodruff, 165

Wyckoff, $14,42,44$

Wyss, 152

Zeus, 110 



15.

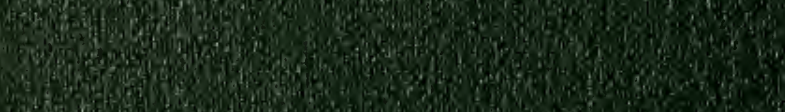

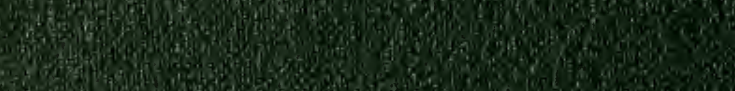

20.

(1)

4. 78

(3)

3.

(1)

S.7.

(3)

3.

54. in

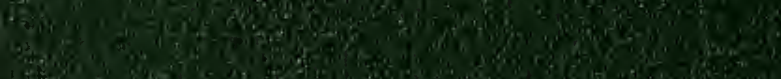

34

$$
30 x^{5}
$$

Wixis

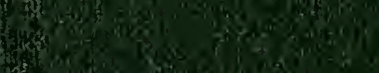

togin of on

13.

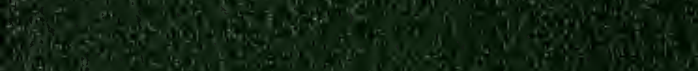

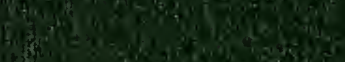

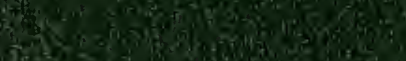

20:3is

(6)

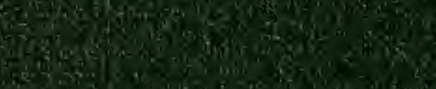

(5)

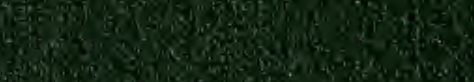

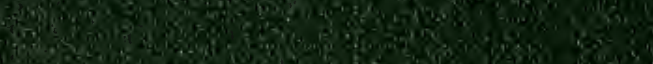

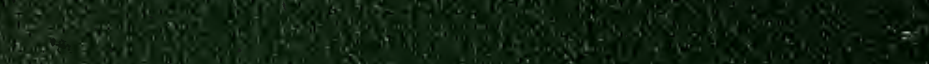

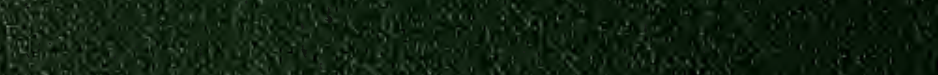

W.

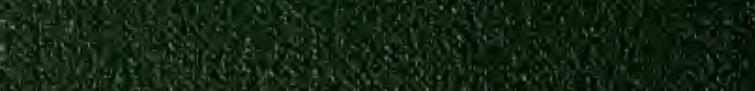

2.4.

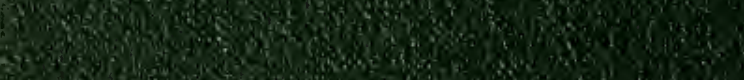

a

art 